\title{
GROUND-WATER HYDROLOGY AND SIMULATED EFFECTS OF DEVELOPMENT IN THE MILFORD AREA, AN ARID BASIN IN SOUTHWESTERN UTAH
}

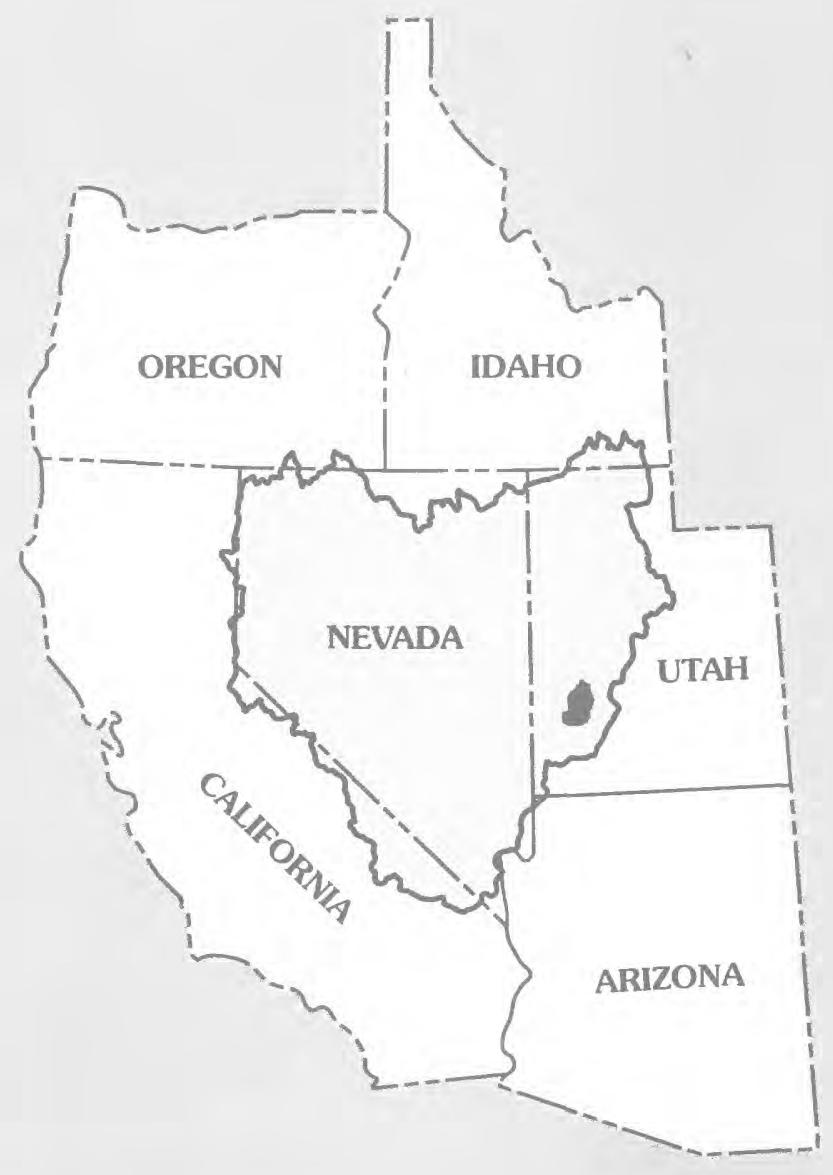




\section{AVAILABILITY OF BOOKS AND MAPS OF THE U.S. GEOLOGICAL SURVEY}

Instructions on ordering publications of the U.S. Geological Survey, along with prices of the last offerings, are given in the currentyear issues of the monthly catalog "New Publications of the U.S. Geological Survey." Prices of available U.S. Geological Survey publications released prior to the current year are listed in the most recent annual "Price and Availability List." Publications that may be listed in various U.S. Geological Survey catalogs (see back inside cover) but not listed in the most recent annual "Price and Availability List" may be no longer available.

Order U.S. Geological Survey publications by mail or over the counter from the offices given below.

\section{BY MAIL}

\section{Books}

Professional Papers, Bulletins, Water-Supply Papers, Techniques of Water-Resources Investigations, Circulars, publications of general interest (such as leaflets, pamphlets, booklets), single copies of Preliminary Determination of Epicenters, and some miscellaneous reports, including some of the foregoing series that have gone out of print at the Superintendent of Documents, are obtainable by mail from

\section{U.S. Geological Survey, Information Services Box 25286, Federal Center, Denver, CO 80225}

Subscriptions to Preliminary Determination of Epicenters can be obtained ONLY from the

\section{Superintendent of Documents Government Printing Office Washington, DC 20402}

(Check or money order must be payable to Superintendent of Documents.)

\section{Maps}

For maps, address mail orders to

U.S. Geological Survey, Information Services Box 25286, Federal Center, Denver, CO 80225

\section{OVER THE COUNTER}

\section{Books and Maps}

Books and maps of the U.S. Geological Survey are available over the counter at the following U.S. Geological Survey Earth Science Information Centers (ESIC's), all of which are authorized agents of the Superintendent of Documents:

- ANCHORAGE, Alaska-Rm. 101, 4230 University Dr.

- LAKEWOOD, Colorado-Federal Center, Bldg. 810

- MENLO PARK, California-Bldg. 3, Rm. 3128, 345 Middlefield Rd.

- RESTON, Virginia-USGS National Center, Rm. 1C402, 12201 Sunrise Valley Dr.

- SALT LAKE CITY, Utah-2222 West 2300 South

- SPOKANE, Washington-U.S. Post Office Bldg., Rm. 135, West 904 Riverside Ave.

- WASHINGTON, D.C.-Main Interior Bldg., Rm. 2650, 18th and C Sts., NW.

\section{Maps Only}

Maps may be purchased over the counter at the following U.S. Geological Survey office:

- ROLLA, Missouri-1400 Independence Rd. 


\title{
Ground-Water Hydrology and Simulated Effects of Development in the Milford Area, an Arid Basin in Southwestern Utah
}

\author{
By JAMES L. MASON
}

REGIONAL AQUIFER-SYSTEM ANALYSIS-

GREAT BASIN-NEVADA AND UTAH

U.S. GEOLOGIGAL SURVEY PROFESSIONAL PAPER 1409-G

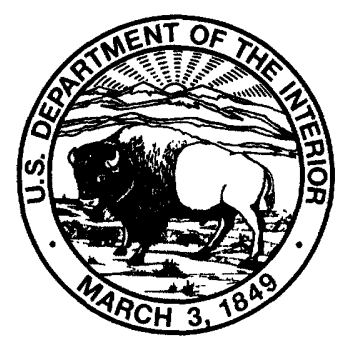




\title{
U.S. DEPARTMENT OF THE INTERIOR BRUCE BABBITT, Secretary
}

\author{
U.S. GEOLOGICAL SURVEY
}

Thomas J. Casadevall, Acting Director

The use of firm, trade, and brand names in this report is for identification purposes only and does not constitute endorsement by the U.S. Government.

Library of Congress Cataloging-in-Publication Data

Mason, James L.

Ground-water hydrology and simulated effects of development in the Milford area, an arid basin in southwestern Utah / by J.L. Mason.

p. cm. -- (Regional aquifer-system analysis--Great Basin, Nevada and Utah) (U.S.

Geological Survey professional paper ;1409-G)

Includes bibliographical references

Supt. of Docs. no.: I 19. 16: 1409-G

1. Ground-water flow--Utah--Milford Region. I. Title. II. Series. III. Series:

Regional aquifer-system analysis--Great Basin, Nevada-Utah.

GB1197.7.M374 1996

551.49'09792'4--dc21

ISBN 0-607-86818-X

For sale by U.S. Geological Survey, Branch of Information Services

Box 25286, Federal Center

Denver, CO 80225 


\section{FOREWORD}

\section{THE REGIONAL AQUIFER-SYSTEM ANALYSIS PROGRAM}

The RASA Program represents a systematic effort to study a number of the Nation's most important aquifer systems, which, in aggregate, underlie much of the country and which represent an important component of the Nation's total water supply. In general, the boundaries of these studies are identified by the hydrologic extent of each system and, accordingly, transcend the political subdivisions to which investigations have often arbitrarily been limited in the past. The broad objective for each study is to assemble geologic, hydrologic, and geochemical information, to analyze and develop an understanding of the system, and to develop predictive capabilities that will contribute to the effective management of the system. The use of computer simulation is an important element of the RASA studies to develop an understanding of the natural, undisturbed hydrologic system and the changes brought about in it by human activities and to provide a means of predicting the regional effects of future pumping or other stresses.

The final interpretive results of the RASA Program are presented in a series of U.S. Geological Survey Professional Papers that describe the geology, hydrology, and geochemistry of each regional aquifer system. Each study within the RASA Program is assigned a single Professional Paper number beginning with Professional Paper 1400.

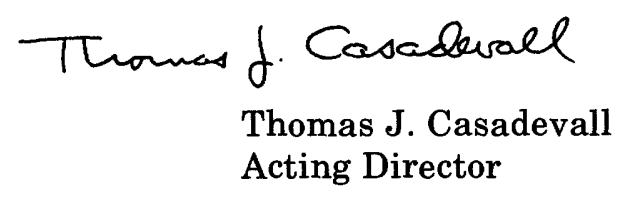





\section{CONTENTS}

Foreword
Introduct
Purpose and scope
Previous studies
Well-numbering system used in Utah
Description of study area
Physiography
Geology
Vlimategetation
Surface water

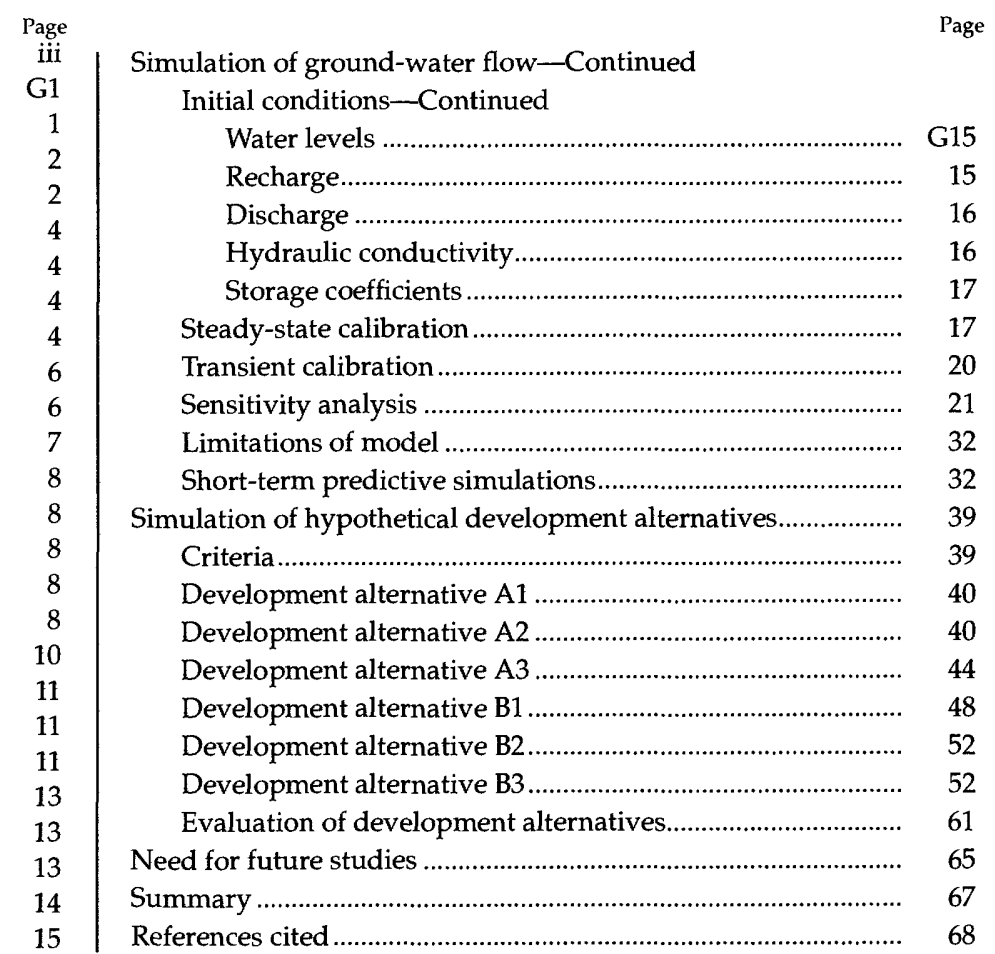

\section{ILLUSTRATIONS}

Page G15 15 16 17 17 20 21 32 32 39 40 40 44 48 52 52 61 65 68

PLATE 1. Map showing grid of the ground-water flow model of the basin-fill aquifer and active cells, specified boundary cells, and cells having pumped wells, Milford area, southwestern Utah.

2. Map showing areal extent of phreatophytes and location of cells in the ground-water flow model having discharge by evapotranspiration, Milford area, southwestern Utah.

FTCURE 1. Map showing location and geographic features of study area

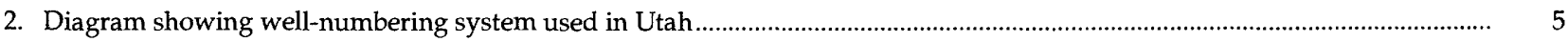

3. Graph showing annual discharge of the Beaver River at Rocky Ford Dam, 1931-84 ….......................................................

4. Map showing potentiometric surface of the principal aquifer, Milford area, 1983 .........................................................................

5.-7. Graphs showing:

5. Percentage change from the preceding year in Beaver River flow and percentage of wells having water-level rises

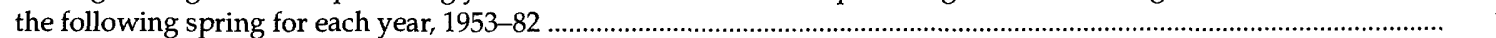

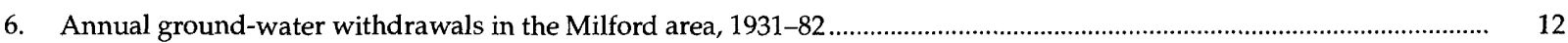

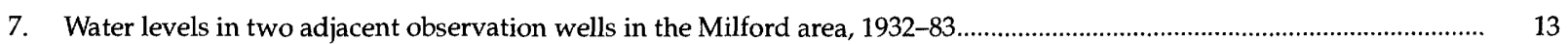


8.-11. Maps showing:

8. Steady-state contours for initial and computed water levels in layer 1

9. Steady-state contours for initial and computed water levels in layer 2

10. Potentiometric contours for the end of the historical transient simulation in layer 2 using constant recharge from seepage of surface water and measured water levels in wells in March 1983.....

11. Model cells receiving constant and variable recharge from seepage of surface water during transient simulations and location of observation wells from which measured water levels are compared to computed water levels.

12.-14. Graphs showing:

12. Measured and computed water-level changes during $1950-83$ for 13 observation wells in the Milford area........

13. Measured and computed water-level changes during 1950-83 for seven observation wells in the Milford area that show minimal differences ( 2 feet or less) in computed levels between constant and variable recharge from seepage...

14. Measured and computed water-level changes during 1950-83 for three observation wells in the Milford area that show substantial differences (more than 2 feet) in computed levels between constant and variable recharge from seepage ..

15.-19. Maps showing:

15. Boundary of active cells during model simulations and areal distribution of cells used for comparison during sensitivity analysis

16. Projected water-level declines in the basin-fill aquifer for 1983-2020, assuming ground-water withdrawals equal to the 1979-82 average rate

17. Projected water-level declines in the basin-fill aquifer for 1983-2020, assuming ground-water withdrawals equal to 1.5 times the $1979-82$ average rate.

18. Projected water-level declines in the basin-fill aquifer for 1983-2020, assuming ground-water withdrawals double the 1979-82 average rate.

19. Simulated water-level declines after 300 years of pumping and areal distribution of cells simulating pumping for development alternative A1

20.-22. Graphs showing:

20. Simulated average water-level decline and recovery in model cells containing pumped wells for development alternative $\mathrm{A} 1$.....

21. Simulated changes in basin inflow and net outflow at general-head boundaries during pumping and recovery for development alternative $\mathrm{A} 1$...

22. Simulated changes in the ratios of water removed from storage during pumping to recharge and water added to storage during recovery to recharge for development alternative $\mathrm{A} 1$.........

23. Map showing simulated residual water-level declines after 300 years of recovery for development alternative A1 ....................

24. Graph showing simulated change in the ratio of natural discharge to recharge during pumping and recovery for development alternative A1

25. Map showing simulated water-level declines after 300 years of pumping and areal distioution of cells simulating for development alternative A2 .

26.-28. Graphs showing:

26. Simulated average water-level decline and recovery in model cells containing pumped wells for development alternative A2

27. Simulated changes in basin inflow and net outflow at general-head boundaries during pumping and recovery for development alternative A2

28. Simulated changes in the ratios of water removed from storage during pumping to recharge and water added to storage during recovery to recharge for development alternative $\mathrm{A} 2$.

29. Map showing simulated residual water-level declines after 300 years of recovery for development alternative A2 ...................

30. Graph showing simulated change in the ratio of natural discharge to recharge during pumping and recovery for development alternative $\mathrm{A} 2$.

31. Map showing simulated water-level declines after 300 years of pumping and areal distribution of cells simulating pumping for development alternative A3.....

32.-34. Graphs showing:

32. Simulated average water-level decline and recovery in model cells containing pumped wells for development alternative $\mathrm{A} 3$.

33. Simulated changes in basin inflow and net outflow at general-head boundaries during pumping and recovery for development alternative $\mathrm{A} 3$.

34. Simulated changes in the ratios of water removed from storage during pumping to recharge and water added to storage during recovery to recharge for development alternative $\mathrm{A} 3$......

35. Map showing simulated residual water-level declines after 300 years of recovery for development alternative $A 3$

36. Graph showing simulated change in the ratio of natural discharge to recharge during pumping and recovery for development alternative A3..

37. Areal distribution of cells simulating pumping for development alternatives B1, B2, and B3

38. Simulated water-level declines after 300 years of pumping for development alternative B1 
39.-41. Graphs showing:

39. Simulated average water-level decline and recovery in model cells containing pumped wells for development alternative B1

40. Simulated changes in basin inflow and net outflow at general-head boundaries during pumping and recovery for development alternative $\mathrm{B} 1$

41. Simulated changes in the ratios of water removed from storage during pumping to recharge and water added to storage during recovery to recharge for development alternative $\mathrm{B} 1$

42. Map showing simulated residual water-level declines after 300 years of recovery for development alternative B1

43. Graph showing simulated change in the ratio of natural discharge to recharge during pumping and recovery for development alternative $\mathbf{B} 1$

44. Map showing simulated water-level declines after 300 years of pumping for development alternative $B 2$

45.-47. Graphs showing:

45. Simulated average water-level decline and recovery in model cells containing pumped wells for development alternative B2

46. Simulated changes in basin inflow and net outflow at general-head boundaries during pumping and recovery for development alternative B2

47. Simulated changes in the ratios of water removed from storage during pumping to recharge and water added to storage during recovery to recharge for development alternative B2

48. Map showing simulated residual water-level declines after 300 years of recovery for development alternative B2.

49. Graph showing simulated change in the ratio of natural discharge to recharge during pumping and recovery for development alternative B2

50. Map showing simulated water-level declines after 50 years of pumping for development alternative B3

51. Simulated average water-level decline and recovery in model cells containing pumped wells for development alternative B3

52. Simulated changes in basin inflow and net outflow at general-head boundaries during pumping and recovery for development alternative B3.

53. Map showing simulated water-level declines after 300 years of pumping for development alternative B3.

54. Graph showing simulated changes in the ratios of water removed from storage during pumping to recharge and water added to storage during recovery to recharge for development alternative B3.

55. Map showing simulated residual water-level declines after 300 years of recovery for development alternative B3.....................

56. Graph showing simulated change in the ratio of natural discharge to recharge during pumping and recovery for development alternative $B 3$.

\section{TABLES}

TABLE 1. Variation in water-budget components during historical transient simulations in the Milford area, Utah

2. Simulated steady-state (1927) and transient-state (1979-82) ground-water budget for the Milford area, Utah

3. Results of sensitivity analysis for ground-water model, Milford area, Utah

4. Projected changes in ground-water budget components due to increased ground-water withdrawals, Milford area, Utah ....

5. Cumulative total of simulated water removed from storage after pumping and recovery for each development alternative in the Milford area, Utah 


\section{GONVERSION FACTORS AND VERTIGAL DATUM}

\begin{tabular}{|c|c|c|}
\hline Multiply inch-pound units & By & To obtain metric units \\
\hline $\begin{array}{r}\text { acre } \\
\text { acre-foot (acre-ft) } \\
\left.\text { acre-foot per square mile (acre-ft/mi } / \mathrm{mi}^{2}\right) \\
\text { acre-foot per year (acre-ft/yr) } \\
\text { cubic foot per second }\left(\mathrm{ft}^{3} / \mathrm{s}\right) \\
\text { foot }(\mathrm{ft}) \\
\text { foot per day }(\mathrm{ft} / \mathrm{d}) \\
\text { foot per mile }(\mathrm{ft} / \mathrm{mi}) \\
\text { foot per second }(\mathrm{ft} / \mathrm{s}) \\
\text { foot squared per day }\left(\mathrm{ft}^{2} / \mathrm{d}\right) \\
\text { foot squared per second }\left(\mathrm{ft}^{2} / \mathrm{s}\right) \\
\text { gallon per minute }(\mathrm{gal} / \mathrm{min}) \\
\text { inch }(\mathrm{in} .) \\
\left.\text { inch per year (inch } / \mathrm{yr}^{2}\right) \\
\text { mile }(\mathrm{mi}) \\
\text { square foot }\left(\mathrm{ft}^{2}\right) \\
\text { square mile }\left(\mathrm{mi}^{2}\right)\end{array}$ & $\begin{array}{l}0.4047 \\
0.001233 \\
476.1 \\
0.001233 \\
0.02832 \\
0.3048 \\
0.3048 \\
0.1894 \\
0.3048 \\
0.0929 \\
0.0929 \\
0.0631 \\
25.4 \\
25.4 \\
1.609 \\
0.0929 \\
2.59\end{array}$ & $\begin{array}{l}\text { square hectometer } \\
\text { cubic hectometer } \\
\text { cubic meter per square kilometer } \\
\text { cubic hectometer per year } \\
\text { cubic meter per second } \\
\text { meter } \\
\text { meter per day } \\
\text { meter per kilometer } \\
\text { meter per second } \\
\text { meter squared per day } \\
\text { meter squared per second } \\
\text { liter per second } \\
\text { millimeter } \\
\text { millimeter per year } \\
\text { kilometer } \\
\text { square meter } \\
\text { square kilometer }\end{array}$ \\
\hline
\end{tabular}

In the first part of the text, all units involving time are given in the commonly used form; however, in the latter part of the text where model simulations are discussed, all units involving time are given in seconds- the time unit used for all simulations. The commonly used units involving time are shown in parentheses.

Sea level: In this report, "sea level" refers to the National Geodetic Vertical Datum of 1929-a geodetic datum derived from a general adjustment of the first-order level nets of the United States and Canada, formerly called Sea Level Datum of 1929. 
REGIONAL AQUIFER-SYSTEM ANALYSIS-GREAT BASIN

\title{
GROUND-WATER HYDROLOGY AND SIMULATED EFFECTS OF DEVELOPMENT IN THE MILFORD AREA, AN ARID BASIN IN SOUTHWESTERN UTAH
}

\author{
BY JAMES L. MASON
}

\begin{abstract}
ABSTRAC'T
A three-dimensional, finite-difference model was constructed to simulate ground-water flow in the Milford area. The purpose of the study was to evaluate present knowledge and concepts of the groundwater system, to analyze the ability of the model to represent past and current (1984) conditions, and to estimate the effects of various groundwater development alternatives. The alternative patterns of groundwater development might prove effective in capturing natural discharge from the basin-fill aquifer while limiting water-level declines.

Water levels measured during this study indicate that ground water in the Milford area flows in a northwesterly direction through consolidated rocks in the northern San Francisco Mountains tow'drd Sevier Lake. The revised potentiometric surface shows a large area t.)r probable basin outflow, indicating that more water leaves the Milford area than the 8 acre-feet per year estimated previously.

Simulations made to calibrate the model were able to aprroximate steady-state conditions for 1927, before ground-water devtlopment began, and transient conditions for 1950-82, during which groundwater withdrawal increased. Basin recharge from the consolidated rocks and basin outflow were calculated during the calibration process. Transient simulations using constant and variable recharge from surface water were made to test effects of large flows in the Beaver River.

Simulations were made to project water-level declines over a 37year period (1983-2020) using the present pumping distribution. Ground-water withdrawals were simulated at 1, 1.5, and 2 times the 1979-82 average rate.

The concepts of "sustained" yield, ground-water mining, and the capture of natural discharge were tested using several hypothetical pumping distributions over a 600 -year simulation period. Simulations using concentrated pumping centers were the least efficient at capturing natural discharge and produced the largest water-level declines. Simulations using strategically placed ground-water withdrawals in the discharge area were the most efficient at eliminating natural discharge with small water-level declines.
\end{abstract}

\section{INTRODUCTION}

The Great Basin Regional Aquifer-System Analysis (RASA) Program, which began in 1980, is the tenth in a series of 25 studies that represents a systematic effort to study regional-aquifer systems throughout the United States. The general objectives for all RASA studies are to describe the present ground-water system and the original ground-water system as it existed prior to development, analyze the changes to the system, synthesize results of this and earlier studies, and provide capabilities through which effects of future ground-water development can be estimated. Specific objectives of the Great Basin RASA (Harrill and others, 1983, p. 2) are as follows:

1. To develop a data base with sufficient data to support computer ground-water flow modeling of basins throughout the region.

2. To delineate and quantitatively describe ground-water basins that are hydraulically connected to form a flow system.

3. To develop a better understanding of recharge and discharge processes.

4. To develop computer ground-water flow models of basins or flow systems considered to be representative of the region.

5. To evaluate relative hydrologic effects of hypothetical development alternatives on the basins or flow systems for which ground-water flow models were constructed. 
6. To design and document generalized ground-water flow models that can be readily applied to similar systems throughout the region.

The Great Basin RASA study area encompasses a series of north-trending mountain ranges separated by alluvial basins. Both the mountain ranges and the basins tend to be 5 to $15 \mathrm{mi}$ wide. Most mountain ranges rise from 1,000 to $5,000 \mathrm{ft}$ above the adjoining basins and can extend for as much as $50 \mathrm{mi}$.

The Great Basin contains a regional aquifer in which most individual basins are linked hydrologically. Some basins form multibasin ground-water flow systems by the movement of water through permeable sedimentary deposits or consolidated rock, whereas, some basins are linked by rivers or surface-water drainages. The remaining basins function as hydrologically isolated basins. All of these basins occupy structural depressions that have been filled with alluvial deposits derived from the adjacent mountain ranges or lacustrine deposits derived from Quaternary lakes. The water supply is derived from precipitation on the adjacent mountains. Annual recharge to the ground-water systems is usually small in relation to the large volumes of water stored (Harrill and others, 1983, p. 3).

Computer simulation of the ground-water system in the Milford area in southwestern Utah (fig. 1) was one of nine modeling efforts included in the Great Basin RASA Program. Like the other modeling efforts, information obtained from the model of the Milford area might be applicable to other parts of the Great Basin. The Milford area was selected for study because of extensive surface-water irrigation, substantial ground-water withdrawals and water-level declines since 1950, and subsurface inflow to and outflow from the basin.

\section{PURPOSE AND SCOPE}

The purpose of this report is to describe the groundwater hydrology of the Milford area, to document the development of the computer ground-water flow model, and to present the results of model simulations. The ground-water system prior to and changes since groundwater development began is described.

For the purposes of this report, the term "Milford area" is the entire study area, including the basin in the center and the surrounding mountain ranges. The term "basin" refers to the structural depression that contains unconsolidated basin-fill deposits and the associated ground-water system.

A three-dimensional, finite-difference model was constructed to simulate ground-water flow in the Milford area. The model was constructed using data obtained mostly during the 1970's; aquifer-test and ground-waterwithdrawal data were reevaluated and some new interpretations were made. Additional data on ground-water levels and withdrawals were collected during 1981-83. Three observation wells were drilled in the northwestern part of the Milford area to define more clearly that part of the ground-water system.

The model, which was calibrated to known steadystate and transient conditions, was used for simulations to estimate future water-level declines using present, and multiples of present, ground-water withdrawals. Hypothetical ground-water-withdrawal alternatives were simulated similar to other basin studies as part of the Great Basin RASA Program.

\section{PREVIOUS STUDIES}

White (1932) estimated evapotranspiration in the Milford area on the basis of pan-evaporation data and diurnal water-level fluctuations in the vicinity of various types of vegetation. His report includes extensive waterlevel data that had not been published previously. Nelson $(1950,1954)$ and Nelson and Thomas (1952) described the ground-water system and the extent of ground-water development in the Milford area. Their reports include ground-water-withdrawal data for individual wells during 1931-53. Criddle (1958) studied consumptive use and irrigation requirements in the area. He estimated consumptive use for each crop type and total consumptive use for the area. Sandberg $(1962,1966)$ provided additional information on the ground-water hydrology of the area, including well information, well logs, water-level measurements, and chemical analyses of ground water. Mower and Cordova (1974) conducted a comprehensive study of the water resources of the Milford area, with emphasis on the ground-water system.

Numerous geophysical and geochemical studies that defined the Roosevelt Hot Springs Known Geothermal Resource Area (KGRA), located along the eastern margin of the Milford area at the base of the Mineral Mountains, were conducted by the University of Utah with funding from the U.S. Department of Energy. Brumbaugh and Cook (1977), Crebs and Cook (1976), and Thangsuphanich (1976) defined the alluvium-consolidated rock interface along the west margin of the Mineral Mountains by using gravity and ground-magnetic surveys. These geophysical surveys partly defined the depth of the basin fill and defined the interface between the alluvium and the consolidated rock along the Mineral Mountains. Gertson and Smith (1979) reported on an east-west seismic-refraction profile across the basin north of Milford. Smith (1980) studied the potential for water recharging the 


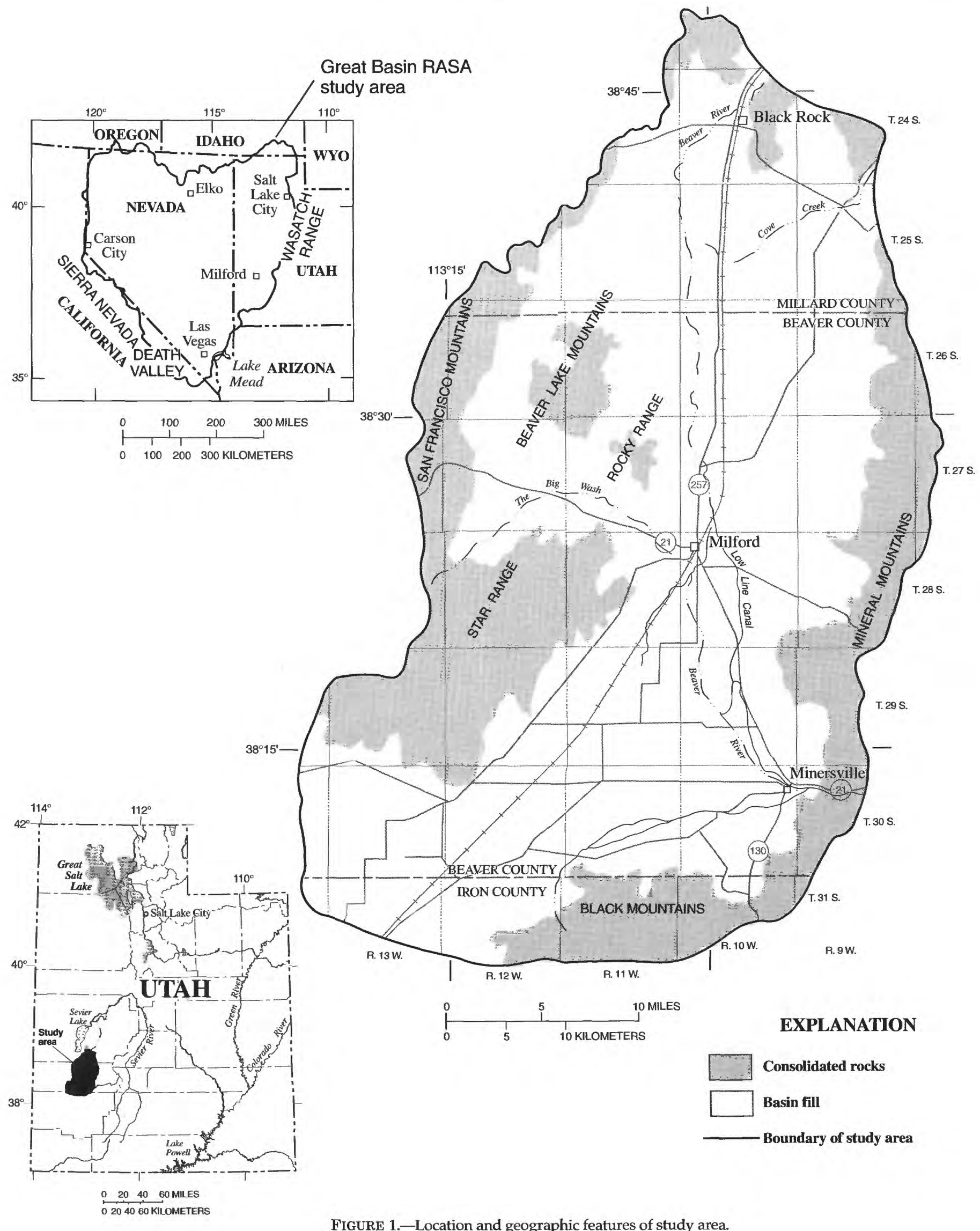

FIGURE 1.-Location and geographic features of study area. 
Tushar Mountains, east of the Milford area, to flow at depth beneath the Mineral Mountains and to discharge in the Milford area. Smith used a vertical, two-dimensional, finite-element model to determine conditions necessary for the hypothesized flow regime, and concluded that flow beneath the Mineral Mountains was not likely. Rohrs and Bowman (1980) and Bowman and Rohrs (1981) studied the stable isotopes of spring and thermal waters from the Roosevelt Hot Springs. They concluded that the thermal waters had a meteoric origin and probably were from the higher altitudes of the Mineral Mountains.

\section{WELL-NUMBERING SYSTEM USED IN UTAH}

The system of numbering wells in Utah is based on the cadastral land-survey system of the U.S. Government. The number, in addition to designating the well, describes its position. The State is divided into four quadrants by the Salt Lake Base Line and the Salt Lake Meridian, and these quadrants are designated by A, B, C, and $D$, indicating respectively, the northeast, northwest, southwest, and southeast quadrants. Numbers designating the township and range, in that order, follow the quadrant letter, and all three are enclosed in parentheses. The number after the parentheses indicates the section and is followed by three letters indicating the quarter section, the quarter-quarter section, and the quarter-quarterquarter section-generally 10 acres; the letters a, b, c, and $\mathrm{d}$ indicate, respectively, the northeast, northwest, southwest, and southeast quarters of each subdivision. The number after the section subdivisions is the serial number of the well within the smallest (10-acre) subdivision. Thus, (C-29-11)27dad-1 designates the first well constructed or visited in the SE1 / 4NE1/4SE1/ 4 sec. 27, T. 29 S., R. $11 \mathrm{~W}$. The numbering system is shown in figure 2 .

\section{DESCRIPTION OF STUDY AREA}

\section{PHYSIOGRAPHY}

The Milford area, which lies within the Basin and Range physiographic province (Fenneman, 1931), covers $1,160 \mathrm{mi}^{2}$ in parts of Millard, Beaver, and Iron Counties, Utah (fig. 1). The center of the Milford area is a northtrending basin, which is bounded by the Mineral Mountains to the east, the Black Mountains to the south, and the San Francisco Mountains to the west. The Beaver Lake Mountains, Rocky Range, and Star Range are small mountain ranges on the west side of the basin. The basin is mostly between altitudes of 4,850 and $5,500 \mathrm{ft}$ above sea level. Most of the mountainous areas are between 5,500 and 9,000 ft; the highest peak $(9,660 \mathrm{ft})$ is in the San Francisco Mountains.

The Milford area is topographically open to the southwest, where no topographic features separate the Milford area from the adjacent Beryl-Enterprise area. Similarly, the north end of the Milford area is topographically open near Black Rock where it joins the Sevier Desert.

The basin is drained by the Beaver River and numerous ephemeral tributaries, which are a part of the Sevier River drainage that terminates in Sevier Lake. The Beaver River channel is normally dry within a short distance downstream from Minersville because of diversions for irrigation. The Beaver River flows westward into the Milford area from Beaver Valley through a narrow gap between the Mineral Mountains and the Black Mountains. The river channel extends north and exits the basin where it is constricted by a basalt flow. Cove Creek, an ephemeral stream, flows into the northeast part of the area through a gap that separates the north end of the Mineral Mountains from the same basalt flow. The Big Wash, an ephemeral stream, drains the area east of the San Francisco Mountains between the Beaver Lake Mountains and the Star Range.

\section{GEOLOGY}

The present physiography of the Milford area is the result of several phases of geologic evolution. Thick sequences of marine, miogeosynclinal strata were deposited from late Precambrian through Devonian time (Hintze, 1973, p. 8). Additional deposits accumulated from Mississippian through Early Triassic time but were generally thinner and representative of a near-shore depositional environment (Hintze, 1973, p. 9). During Late Triassic to early Cenozoic time, this part of western Utah was a rugged highland caused by thrust faulting and folding of the Sevier Orogeny (Hintze, 1973, p. 9). During the Oligocene, volcanic activity deposited extensive layers of ignimbrites, lava flows, and volcanic breccias in western Utah (Hintze, 1973, p. 9). From Miocene to Holocene time, the Oligocene volcanic rocks and the earlier miogeosynclinal strata were subjected to block-faulting and crustal extension, which resulted in north-trending, alternating mountain ranges and basins. Erosional debris partially filled the basins prior to and during the deposition of Lake Bonneville lacustrine sediments (Hintze, 1973, p. 9).

Consolidated rocks in the mountains surrounding the basin vary in age and lithology from Precambrian metasediments to Quaternary basalt and rhyolites. The Mineral Mountains on the east are an uplifted horst, most of which is a granitic pluton. The pluton has been $\mathrm{K}-\mathrm{Ar}$ (potassium-argon) dated between 9.4 and 14.0 m.y. (mil- 


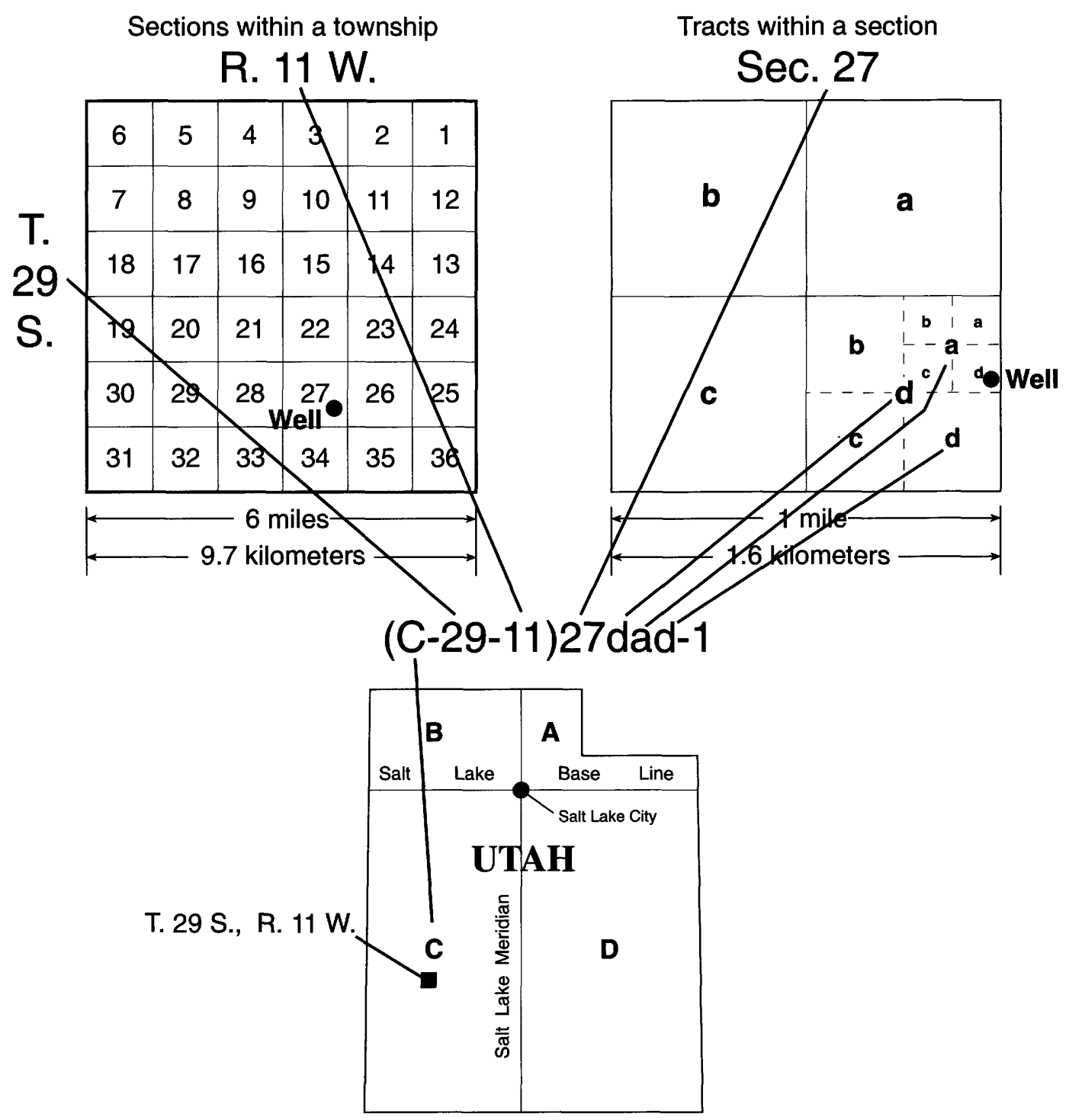

FIGURE 2.-Well-numbering system used in Utah. 
lion years) (Armstrong, 1970, p. 217; Ward and others, 1978, p. 1520) and has intruded gneisses of probable Precambrian age, which are exposed along the western margin of the pluton. Repeated igneous activity from middle Tertiary to Quaternary time is evident. Middle Tertiary lavas are exposed on the south flank of the Mineral Mountains. This volcanic activity was followed by the emplacement of rhyolite on the north and west flanks of the Mineral Mountains that postdates the pluton. The youngest rhyolites have been K-Ar dated between 0.8 and 0.5 m.y. (Ward and others, 1978, p. 1520) and are distributed along the western flank. Paleozoic and Mesozoic sedimentary rocks crop out on the north and south ends of the Mineral Mountains.

In the north end of the San Francisco Mountains, Precambrian and Cambrian metasediments overlie Cambrian quartzites as a result of the Frisco Thrust (Lemmon and Morris, 1983). In the San Francisco Mountains and northern Beaver Lake Mountains, Precambrian and Cambrian metasediments overlie Ordovician through Mississippian limestone, dolomite, and quartzite due to the Beaver Lake Thrust (Lemmon and Morris, 1983). The southern San Francisco Mountains and Star Range are composed primarily of Tertiary latitic ignimbrites and late Tertiary basalt and andesite flows with a few exposures of upper Paleozoic carbonate rocks and Mesozoic sandstone (Hintze, 1980).

The Black Mountains are composed primarily of late Tertiary volcanic rocks with small, intermittent outcrops of basalt. Numerous faults are also present (Hintze, 1980).

Condie and Barsky (1972, p. 337) indicated the Black Rock basalts predated Lake Bonneville. The basalts overlie white tuffaceous clay, silt, and marl of early Pleistocene age. The contact is exposed along cliff faces east of Black Rock in the north end of the study area.

On the basis of gravity data, Carter and Cook (1978, p. 89) suggested that the basin-fill thickness is $1.5 \mathrm{~km}$ (about $4,900 \mathrm{ft})$. In a later study, Gertson and Smith (1979, p. 83) estimated the basin-fill thickness to be $1.8 \mathrm{~km}$ (about 5,900 $\mathrm{ft})$.

On the basis of a seismic refraction profile, Gertson and Smith (1979, p. 57) defined two layers within the basin-fill deposits. The lower layer ranges in thickness from $0 \mathrm{~km}$ at the margin of the basin to about $1.2 \mathrm{~km}(3,900 \mathrm{ft})$ in the center of the basin (Gertson and Smith, 1979, p. 89). The composition of the lower layer is unknown because no well has penetrated this layer; however, Gertson and Smith $(1979$, p. 58$)$ reported that seismic velocity values recorded for the lower layer were similar to those that Arnow and Mattick (1968, p. B80) assigned to Tertiary sediments. These higher velocity values generally are related to greater cementation and compaction and lower porosity values.

The upper layer of the basin fill ranges in thickness from 0.1 to $0.6 \mathrm{~km}$ (about 300 to 2,000 ft)(Gertson and Smith, 1979, p. 89). The upper layer of the basin fill consists of lacustrine deposits of fine-grained clay, silt, and marl along the axis of the basin that are interlayered and intertongued with deltaic and alluvial deposits of clay, silt, sand, and gravel. On the basis of scant well-log data, the lacustrine deposits are more prevalent in the northern one-half of the basin. Along the margins of the basin near the mountain fronts alluvial fans are present. Well-log data from the eastern margin of the basin indicate deposits of mixed clay and sand; whereas well-log data from the western margin of the basin indicate alternating layers of clay and unsorted sand and gravel. Shoreline deposits of sand and gravel reworked from the alluvial fans are present to an altitude of 5,120 ft (Dennis, 1942, p. 124).

The basement rocks below the basin fill are assumed to be Precambrian gneisses. Gertson and Smith (1979, p. $60)$ reported that seismic velocity values are similar to those recorded for a sonic $\log$ in a test well drilled into Precambrian gneisses on the western edge of the Mineral Mountains.

\section{CLIMATE}

The climate of the study area varies from semiarid on the basin floor to subhumid at higher altitudes in the surrounding mountains. The mean annual temperature at Milford is $49.3^{\circ} \mathrm{F}$; summer highs sometimes exceed $100^{\circ} \mathrm{F}$, and winter lows are sometimes less than $-10^{\circ} \mathrm{F}$ (Mower and Cordova, 1974, p. 9). Average growing season is 126 days, usually from mid-May to late September (Criddle, 1958, p. 4). Average annual precipitation at Milford was 8.79 inches for 1932-83 (Avery and others, 1984, p. 62). The 1931-60 normal annual precipitation was 26 in. in the Mineral Mountains and as much as 16 in. in the San Francisco Mountains (U.S. Weather Bureau, 1963). Mower and Cordova (1974, p. 9) reported that average pan evaporation for April-October during 1953-71 was 78 inches/yr. They attributed the high rate of evaporation to frequent wind.

\section{VEGETATION}

In the higher altitudes of the surrounding mountains, the predominant vegetation is juniper (Juniperus sp.) and pinyon pine (Pinus edulis); however, in the Mineral Mountains, scrub oak (Quercus gambelii Nutt.) is more prevalent. Along the margins of the basin, the predominant vegetation is sagebrush (Artemisia tridentata), with some rabbitbrush (Chrysothamnus nauseosus) and shadscale (Atriplex confertfolia); all are low to the ground. 


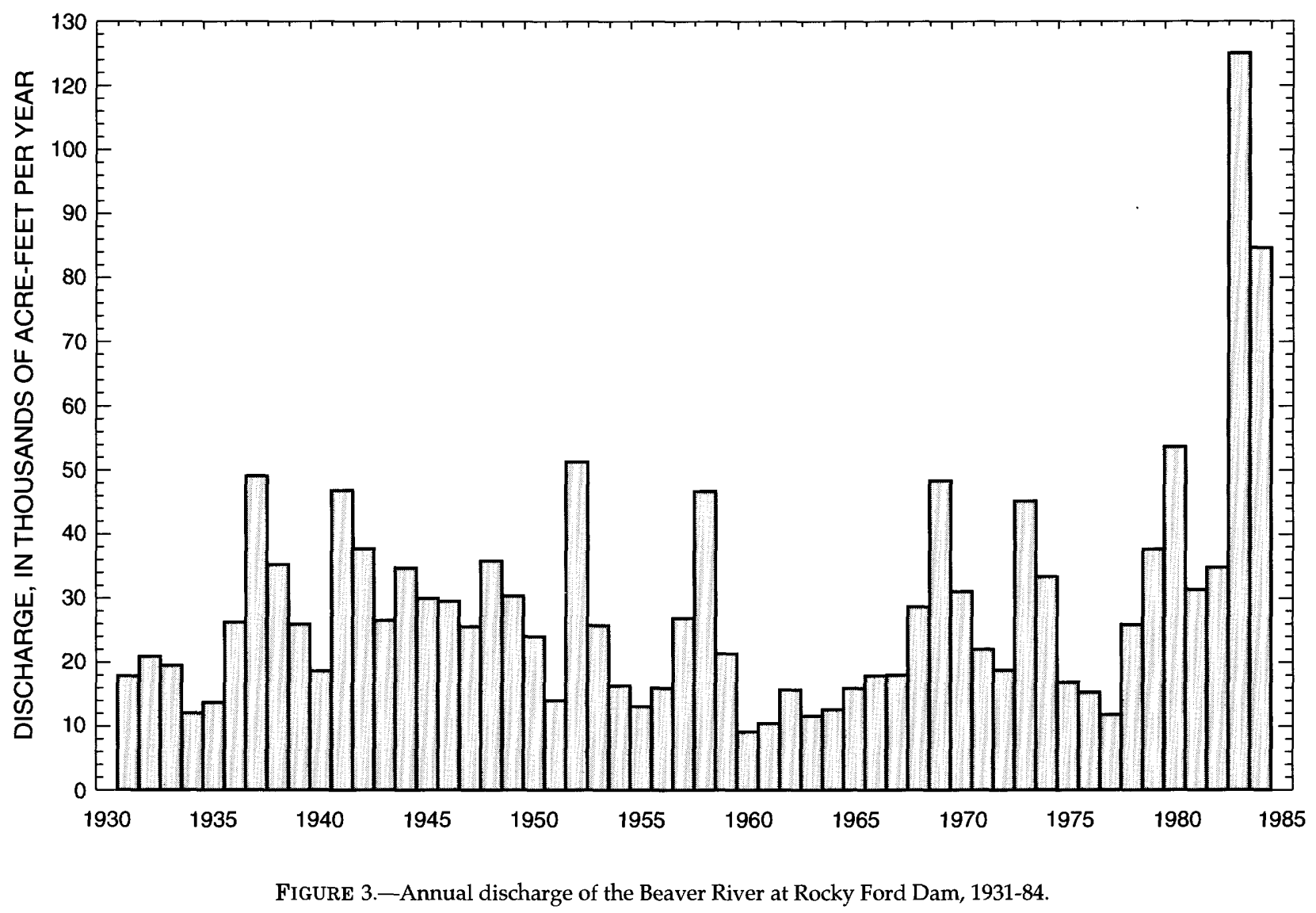

Along the axis of the basin where the water table is shallow and the land is not irrigated, stands of greasewood (Sarcobatus vermiculatus), rabbitbrush, saltgrass (Distichlis stricta), and pickleweed (Allenrolfea occidentalis) are the principal phreatophytes; of these, greasewood is the most common. Willow (Salix sp.) and saltcedar (Tamarix gallica), which are phreatophytes, grow along the Beaver River channel and major canals. Mower and Feltis (1968, p. 14) reported that saltcedar was introduced into the Sevier Desert to the north prior to 1950, and saltcedar probably was introduced into the Milford area about the same time.

Cottonwood (Populus sp.) and willow grow in upland areas near springs. Cottonwood and other trees grow in the center of the valley where they were planted for shade and windbreaks.

\section{SURFACE WATER}

The Beaver River was a perennial stream through the Milford area until 1914, when Rocky Ford Dam was constructed to impound water $5 \mathrm{mi}$ east of Minersville, outside the study area. Flow in the Beaver River channel below the reservoir now is small; practically all the water is diverted for irrigation. Only in wet years is the dis- charge from the reservoir great enough to cause extensive flow in the channel. In winter months, $5 \mathrm{ft}^{3} / \mathrm{s}$ or less flows in the channel (Nelson, 1950, p. 185).

Annual discharge of the Beaver River at Rocky Ford Dam (fig. 3) averaged 26,100 acre-ft/yr from 1931 to 1982 (Appel and others, 1983, p. 77). During 1931-82, the minimum annual discharge, 9,150 acre-ft, occurred in 1960 (Mower and Cordova, 1974, p. 11). Annual discharges of 125,000 acre-ft in 1983 and 94,800 acre-ft in 1984, far larger than the maximum during 1931-82, were reported by Avery and others (1984, p. 60) and Seiler and others (1985, p. 61).

All other streams are ephemeral and ungaged. Only rarely (such as during intense rainfall) does any appreciable flow reach the lower part of the basin. Using the channel-geometry method of Moore (1968, p. 29-39), Mower and Cordova (1974, p. 11) estimated mean annual runoff from 13 ephemeral streams to be 7,100 acre-ft. These 13 streams drain $160 \mathrm{mi}^{2}$, producing an average yield of about 45 acre- $\mathrm{ft} / \mathrm{mi}^{2}$. By applying this yield to the entire $540 \mathrm{mi}^{2}$ of mountainous area, Mower and Cordova (1974, p. 11) estimated mean annual runoff to be about 24,000 acre-ft. 
Practically all flow entering the area in the Beaver River channel is diverted near Minersville. The water enters either the Utopia Ditch and Minersville Canal for irrigation in the area near Minersville, or into the Low Line Canal that carries water north toward Milford.

\section{GROUND-WATER HYDROLOGY}

\section{CONSOLIDATED ROGKS}

The consolidated rocks in the Milford area can be divided into three hydrogeologic units. Precambrian gneiss and Tertiary and Quaternary granite and basalt are grouped into one unit because of their assumed overall low permeability and porosity. Although the hydrologic properties of basalt can be markedly different than gneiss and granite, there is no information in the Milford area to differentiate between these rock types. These consolidated rocks might contain water in widely spaced joints; and if the joints are large and well connected, the granite and basalt can accept large quantities of water. The consolidated rocks could contribute a substantial quantity of water to the unconsolidated basin fill by subsurface flow. Wells intersecting systems of open joints could produce moderate quantities of water.

The second unit includes Tertiary fine-grained extrusive rocks other than basalts, such as latitic ignimbrites and andesite flows. These rocks contain small quantities of water in poorly developed and poorly connected joints. This unit probably does not accept an appreciable quantity of water for recharge and would not yield water readily to wells.

The third unit includes Precambrian through Cretaceous carbonate rocks, sandstones, and metasedimentary rocks that have hydrologic properties similar to the Tertiary and Quaternary granite and basalt. These rocks could have joints and fractures that contain water but the carbonate rocks have the additional potential for storing and transmitting large quantities of water due to enlargement of the fractures through dissolution. The sandstones could have some primary permeability related to intergranular porosity, but it probably would be subordinate to secondary permeability from fracturing and jointing.

\section{UNCONSOLIDATED BASIN FILL}

\author{
DESGRIPTION
}

The ground-water system of the Milford area is made up of unconsolidated basin fill. The ground-water system is unconfined along the margins of the basin, but becomes confined in the center of the southern one-half of the basin. The upper 200 to $300 \mathrm{ft}$ of the saturated basin fill in this area is under both unconfined and semiconfined conditions. The lateral extent of the confined aquifer is assumed to coincide with the main area of ground-water development. The confined aquifer might extend further to the southwest and toward the mountains, but this is unknown because of a lack of well data outside the developed area. The depth to the bottom of the main confining bed ranges from 200 to $300 \mathrm{ft}$ as shown by Mower and Cordova (1974, pl. 2A and 2B). Because of the lack of data, a lower limit for the confined or principal basin-fill aquifer cannot be determined except by geophysical methods, which suggest a total thickness of $2,000 \mathrm{ft}$.

In the center of the northern one-half of the basin, water from the basin fill discharges in this area where the hydraulic head is near the land surface. Data are insufficient, however, to determine whether the ground-water system in the northern one-half of the basin is truly confined with a confining layer at depth, or whether the upward hydraulic gradient is associated only with upward movement of ground water to a discharge area at land surface.

Along the center of the southern one-half of the basin, the basin fill is composed of alternating clay, sand, and gravel. The basin fill along the eastern margin of the basin, for the most part, is composed of unsorted clay and sand with intermixed gravel in the alluvial fans. In some areas along the western margin of the basin, sequences of alternating clay, sand, and gravel are present, but no data are available to determine if any of the clay layers act as confining beds. Along the center of the northern one-half of the basin, the basin fill is generally composed of unsorted clay and sand.

\section{MOVEMENT}

The general direction of ground-water movement is from south to north with a strong east to west component, as shown in figure 4. Subsurface flow enters the groundwater system from the Beryl-Enterprise area to the southwest and from the southeast under the Beaver River channel and through its associated alluvial fan. Along the eastern margin of the basin, the hydraulic gradient indicates flow toward the axis of the basin. 


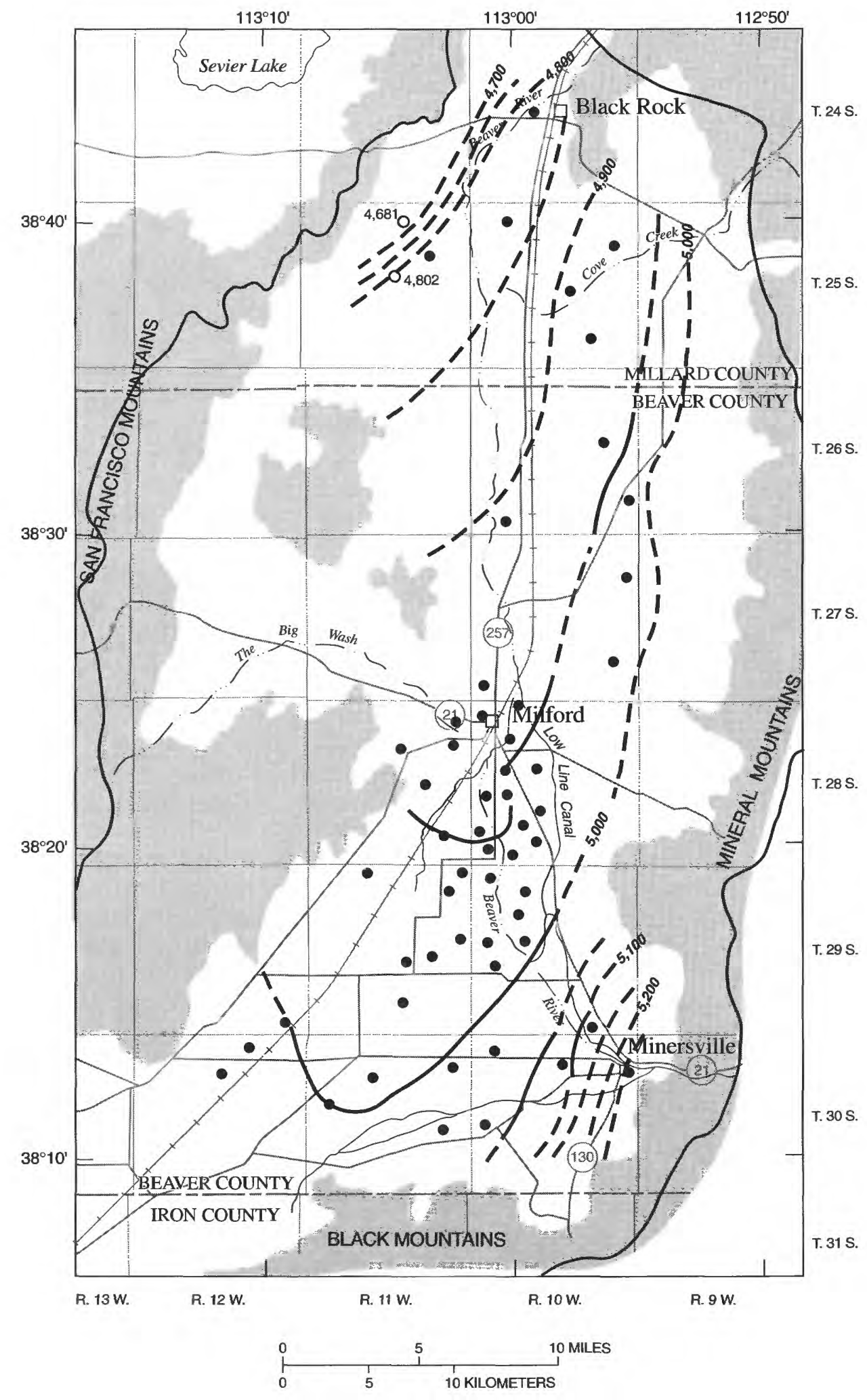

EXPLANATION

Consolidated rocks

Basin fill

- 5,000 - Potentiometric contour-

Shows altitude at which water level would have stood in tightly cased wells, March 1983. Dashed where approximately located.

Contour interval is 50 feet.

Datum is sea level

Boundary of study area

Observation well

$0^{4,802}$

Observation well (dry) -

Number is altitude of bottom of well, in feet above sea level

FIGURE 4.-Potentiometric surface of the principal aquifer, Milford area, 1983. 
Along the southwestern margin of the basin, limited water-level data indicate that the ground-water flow direction is basically to the north, paralleling the Star Range, with little movement to the east of these uplands. This suggests limited inflow from the consolidated rocks. Based on information from three test holes drilled during this project, the ground-water gradient in the northwest part of the basin indicates movement through the consolidated rocks in the north end of the San Francisco Mountains toward Sevier Lake.

\section{RECHARGE}

Subsurface inflow from consolidated rocks along the mountain fronts was estimated by Mower and Cordova (1974, p. 22) to be 16,000 acre-ft/yr. This estimate was derived by subtracting all known and estimated sources of recharge from the estimated total ground-water discharge under steady-state conditions, assuming that recharge equals discharge. They also assumed that subsurface inflow from consolidated rocks was distributed along the surrounding mountains. On the basis of the revised direction of ground-water flow (fig. 4) as compared to the direction of ground-water flow shown in Mower and Cordova (1974, pl. 4), the major source of subsurface inflow from consolidated rocks is from the Mineral Mountains. By using the approach of Maxey and Eakin (1949, p. 40), which consists of assuming that a percentage of precipitation over upland areas seeps into consolidated rocks, subsurface inflow from the Mineral Mountains was estimated to be more than 15,000 acre-ft/yr. This is almost equal to the recharge estimated for the whole area by Mower and Cordova. On the basis of ground-water flow direction, the mountains to the south and west do not contribute an appreciable quantity of subsurface inflow from consolidated rocks.

In the extreme northern part of the basin, east of Black Rock, an unknown but large quantity of subsurface inflow enters the unconsolidated basin-fill aquifer from basalt that overlies clastic deposits of early Pleistocene age. Mower and Cordova (1974, p. 62) estimated the discharge from one spring orifice to be from 500 to $1,000 \mathrm{gal} / \mathrm{min}$.

Subsurface inflow from tributary basins was estimated by Mower and Cordova $(1974$, p. 16) to be 1,700 acre$\mathrm{ft} / \mathrm{yr}$ by using Darcy's Law. The contribution was estimated to be 1,000 acre-ft/yr from the Beryl-Enterprise area and 700 acre-ft / yr from Beaver Valley. Later, during calibration of a ground-water flow model for the BerylEnterprise area, Mower (1982, p. 47), estimated the outflow from that area toward Milford to be 2,100 acre-ft/ yr. This study did not attempt to collect new field data to verify these estimates.

Through canal-loss measurements, Mower and Cordova $(1974$, p. 18) estimated that 34 percent of the water diverted from the Beaver River infiltrates to the groundwater system. They reported that approximately 4 percent probably is consumed by vegetation, leaving 30 percent to recharge the ground-water system. Also, they reported that the long-term average annual recharge from losses along the $23 \mathrm{mi}$ of canals in the Milford area was 8,300 acre-ft/yr.

Seepage from irrigated lands contributes a substantial amount of water to the ground-water system. Willardson and Bishop (1967, p. 35) reported water-application efficiencies of 60 to 80 percent (losses between 40 and 20 percent) with furrow or flooding methods. Losses may decrease with more efficient irrigation practices. Assuming an average seepage loss of 30 percent of the water applied to irrigated lands (ground water and surface water), Mower and Cordova (1974, p. 15) estimated that 22,700 acre-ft/yr infiltrates to the ground-water system, based on irrigation practices for 1970-71. They also estimated that infiltration from precipitation on irrigated lands was 2,000 acre- $\mathrm{ft} / \mathrm{yr}$, and infiltration from lawns and gardens was 100 acre-ft/yr.

Mower and Cordova (1974, p. 18) assumed that 30 percent of the annual runoff in ephemeral stream channels infiltrates to the ground-water system. Using the $24,000 \mathrm{acre}-\mathrm{ft} / \mathrm{yr}$ estimate for ephemeral streamflow reported in the surface-water section of this report, this yields 7,200 acre-ft/yr. This includes underflow along The Big Wash, which was estimated to be 2,200 acre-ft/ yr. With the revised flow system, which is in contrast to the flow system shown in Mower and Cordova (1974, pl. 4), only recharge from the Mineral Mountains affects the entire ground-water system. The Mineral Mountains cover an area of $125 \mathrm{mi}^{2}$, about 25 percent of the mountainous area. Using the assumptions of Mower and Cordova (1974, p. 18), 25 percent of 24,000 acre-ft, or 6,000 acre-ft, would run off the Mineral Mountains and would be available for recharge. Thirty percent of that figure gives 1,800 acre- $\mathrm{ft}$ of recharge to the ground-water system from these mountains. Minimum flow in the Beaver River channel is about $5 \mathrm{ft}^{3} / \mathrm{s}$ during the winter (Nelson, 1950, p. 185), which is about 1,800 acre-ft/yr, assuming a 6-month lowflow period. All of this flow is assumed to recharge the ground-water system.

Water-level fluctuations in wells within the area of ground-water withdrawal are a response to the long-term trends of precipitation, recharge from the Beaver River and the associated surface-water irrigation system, and ground-water withdrawals. Water levels within this area declined steadily from 1950 to 1968 . Since 1968, water levels generally have declined at a slower rate with some rises that probably are related to high flows in the Beaver River. Similar trends can be seen by comparing the percentage of rise or decline of flow in the Beaver River from 
one year to the next to the percentage of wells that shows a rise during the following spring, especially for years with a substantial increase of flow in the Beaver River (fig. 5). Water-level rises in wells near the Beaver River channel or near large canals could be the result of an increase in the infiltration of surface-water in combination with a decrease in ground-water withdrawals because of the availability of surface water.

\section{DISCHARGE}

Mower and Cordova (1974, p. 32) estimated evapotranspiration to be 24,000 acre- $\mathrm{ft}$ in 1971, compared to an estimated 33,000 acre-ft for 1927 that they obtained by adjusting White's 1932 estimate. As reported by Mower and Cordova (1974, table 10), the difference in evapotranspiration is due to declining water levels within the area of ground-water development. The phreatophyte area mapped by Mower and Cordova (1974, pl. 3) was field checked during this study and no substantial differences were found.

Subsurface outflow toward the north to the Sevier Desert was estimated to be 8 acre-ft/yr by Mower and Cordova (1974, p. 33) using Darcy's Law. A low estimate for transmissivity of $75 \mathrm{ft}^{2} / \mathrm{d}$ was used in the calculation; however, based on the new direction of ground-water flow as compared to the direction of ground-water flow shown in Mower and Cordova (1974, pl. 4), the main component of basin outflow is toward the northwest through the consolidated rocks at the north end of the San Francisco Mountains. Model simulations of the Milford area, discussed in a later section of this report, provided an estimate for this outflow.

Since 1931, the U.S. Geological Survey, in cooperation with the State of Utah, has estimated ground-water withdrawals in this area. The estimates were made from periodic discharge and power-consumption measurements and yearly power-consumption records, or from a summation of water from irrigation wells that have water meters. From 1931 through 1949, ground-water withdrawals averaged 16,100 acre- $\mathrm{ft} / \mathrm{yr}$, with a maximum of 22,760 acre-ft in 1947, and a minimum of 10,860 acre-ft in 1931. Discharge from wells began to increase markedly in 1949 (fig. 6). From 1950 through 1982, ground-water withdrawals averaged 49,000 acre-ft/yr. Since 1949 , the maximum withdrawal was 70,200 acre-ft in 1974, and the minimum withdrawal was 30,900 acre-ft in 1950 . Associated with the increase in ground-water withdrawals, water levels began to decline after 1950 as shown by the hydrographs of two observations wells (fig. 7). The large fluctuations in the hydrographs are a result of seasonal variations due to pumping; however, the long-term trend of water-level decline is clearly visible.

\section{HYDRAULIC PROPERTIES}

The hydraulic properties of an aquifer describe its ability to transmit and store water. Transmissivity, which depends on the hydraulic conductivity and the saturated thickness of the porous medium, can be determined from aquifer-test data and estimated from specific capacities. Mower and Cordova (1974, p. 13) reported transmissivity values ranging from 1,000 to about $40,000 \mathrm{ft}^{2} / \mathrm{d}$, based on their analysis of aquifer-test data by the Theis curvematching procedure (Lohman, 1972, p. 34) and the Cooper and Jacob straight-line solution (Lohman, 1972, p. 19). As part of this study, aquifer-test data collected by Mower and Cordova were analyzed using the Hantush modified method (Lohman, 1972, p. 32). Transmissivity values ranged from about 1,000 to $55,000 \mathrm{ft}^{2} / \mathrm{d}$ with the highest values in the south end of the developed area as indicated by the concentration of observation wells in figure 4 .

Mower and Cordova (1974, p. 13) reported specificyield values from 0.04 for clayey silt to 0.2 for sandy gravel. They determined the values from short-term aquifer tests and the neutron-radiation method described by Keys and MacCary (1971, p. 74-86). They also reported a storage coefficient value of $1.0 \times 10^{-3}$ for the confined aquifer in the central part of the basin. Storage coefficient values were determined in the present study from aquifer-test data using the Hantush modified method. Values ranged from 0.002 to $6.0 \times 10^{-5}$.

\section{STORAGE}

Mower and Cordova (1974, p. 24) estimated that 40 million acre-ft of ground water is stored in the groundwater system. They derived this estimate by multiplying the volume of saturated materials, 95 million acre-ft, by an average water content of 40 percent by volume. They also estimated water content for different lithologies from 110 relatively undisturbed soil samples and from neutron moisture-probe measurements. Lithologic logs and the estimated values for water content were used to determine average water content for the entire ground-water system. Their estimated volume of saturated materials, however, was based on a maximum depth of slightly over $500 \mathrm{ft}$. Drilling since the early 1970's has shown that the depth of saturated materials is greater than $500 \mathrm{ft}$ and that the bottom of the ground-water system has not been reached; therefore, the amount of water in storage probably is greater than the value estimated by Mower and Cordova.

Mower and Cordova (1974, p. 27) reported that less than one-half of the estimated 40 million acre- $\mathrm{ft}$ stored in the ground-water system may be recoverable. The amount of recoverable water in storage is determined from the volume of the ground-water system and the spe- 

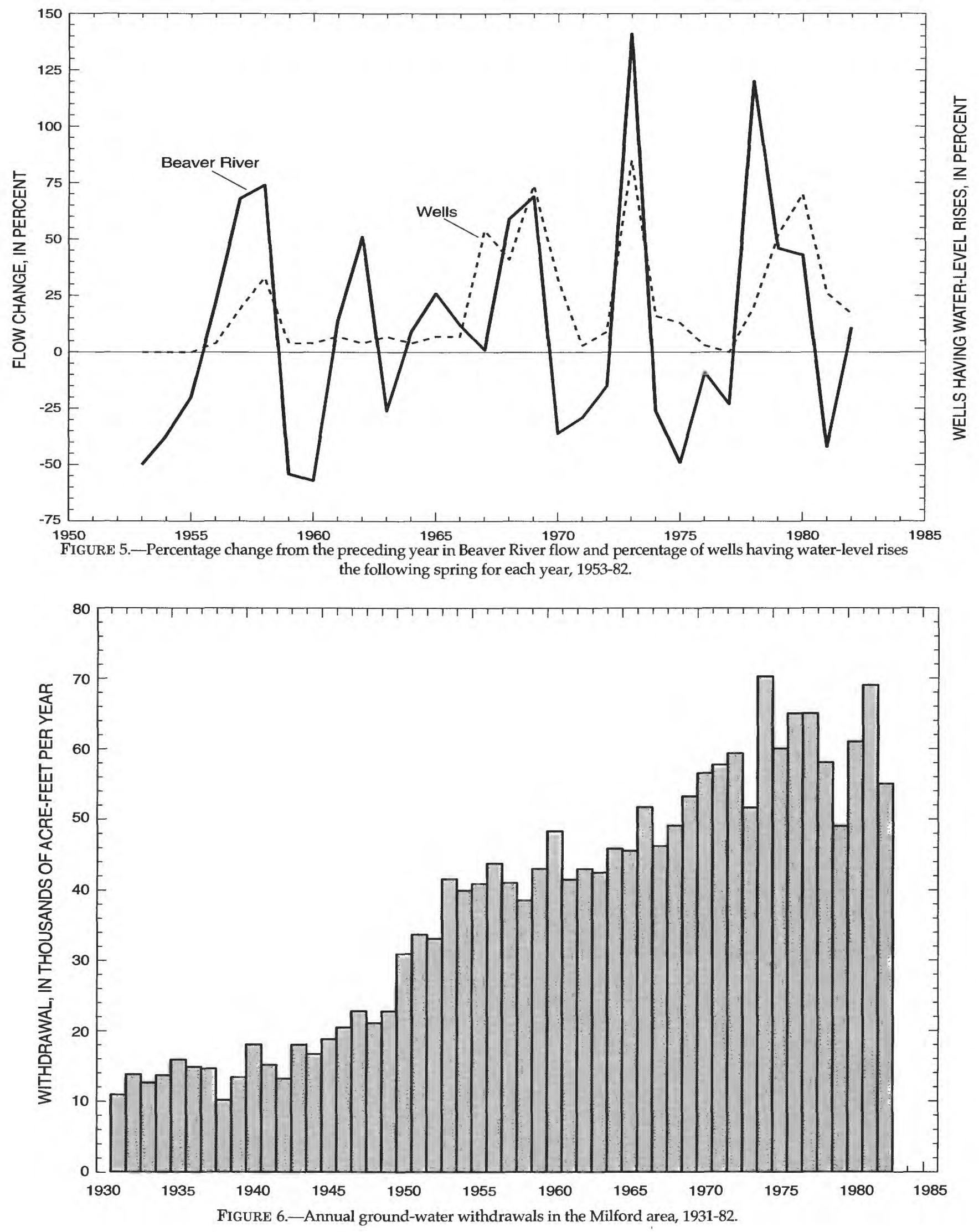


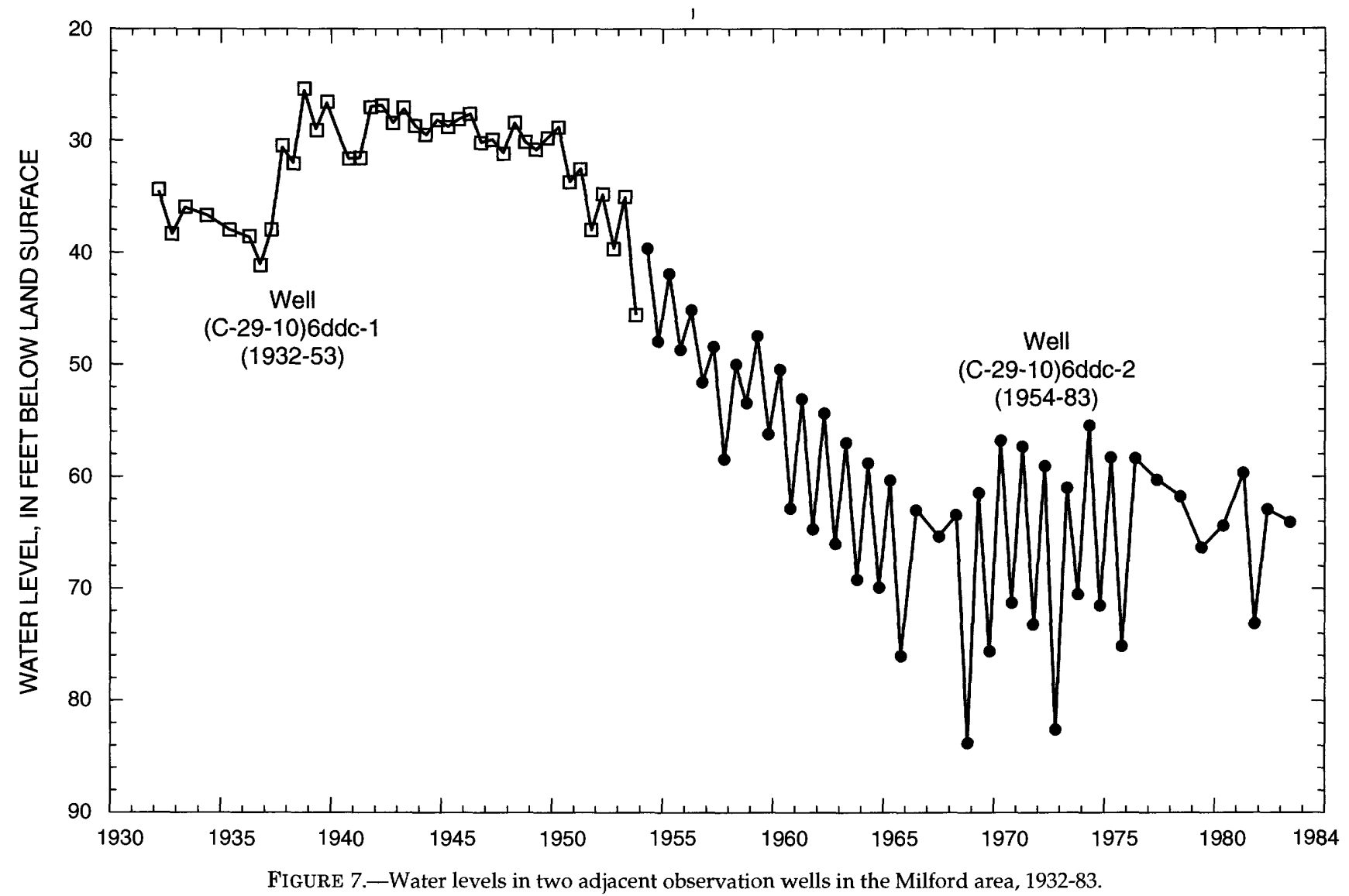

citic yield, assuming that the water levels will have been lowered so that the confined aquifers have been dewatered; thus, a specific yield representative of water-table conditions will determine the amount of water released from storage. The ground-water system in the Milford area covers approximately $550 \mathrm{mi}^{2}$. Assuming an average saturated thickness of $400 \mathrm{ft}$ for the basin fill and a specific yield of 0.15 , the amount of recoverable water in storage was estimated to be 21 million acre-ft.

\section{SIMULATION OF GROUND-WATER FLOW}

A three-dimensional, finite-difference computer program developed by McDonald and Harbaugh (1988) was used to describe ground-water flow in the basin fill in the Milford area. The finite-difference algorithm used in their computer program can generate only an approximate solution to the partial-differential equation that describes ground-water flow; therefore, the model needs to be considered a tool to help describe the ground-water system. The ground-water model was used to (1) verify or improve estimates of recharge and discharge and the hydraulic properties that describe the basin-fill aquifer; and (2) simulate past and future stresses on the basin-fill aquifer. Both short-term stresses using the present pat- tern of ground-water withdrawal, and long-term stresses using hypothetical distributions of ground-water withdrawal were simulated. The short-term simulations projected effects of present withdrawals and potential increases in withdrawals. The long-term simulations tested the effects of three kinds of ground-water development: "sustained" yield, ground-water mining, and the capture of natural discharge.

\section{MODEL DESIGN}

\section{MODEL GRID AND LAYERS}

The three-dimensional, ground-water flow model uses a block-centered or cell-oriented grid system as described by McDonald and Harbaugh (1988, p. 5-1). The grid used for the Milford model consists of 55 rows and 29 columns. Cell spacing ranged from 0.5 to $1.5 \mathrm{mi}$. The smallest cells, located in the area with numerous wells, cover $0.25 \mathrm{mi}^{2}$; largest cells cover $1.5 \mathrm{mi}^{2}$. The area of active cells (those actually included in the model calibrations) used in the final model design are shown on plate 1.

The original model design included two layers; an unconfined upper layer and a confined lower layer, except 
unconfined at the margins of the basin where water levels were below the base of the upper layer. Thickness for the upper layer was held constant at $200 \mathrm{ft}$, conforming to surface topography.

In some cells along the active edge of the upper layer, the saturated thickness of the porous medium was small. During initial transient simulations, many of these active cells went dry within a short period of time, probably causing adjacent cells to go dry prematurely. In the actual system, water levels do not decline this abruptly, so the ground-water model was redesigned to prevent cells from going dry prematurely by including three layers. The upper layer (layer 1), which represents the unconfined basin fill, was deepened to $250 \mathrm{ft}$ below land surface along the axis of the basin. The bottom of layer 1 was inclined in a north direction to parallel the natural inclination of the land surface. Also, the bottom of layer 1 was made uniform in an east and west direction from the axis, thus increasing its thickness toward the mountains. This design eliminated the problem of cells going dry because almost all cells in layer 1 have large saturated intervals, except in the extreme northwest corner. Due to the steep hydraulic gradient in that area, a few cells have small saturated intervals, and some cells are inactive because the water level is below the bottom of layer 1 .

The middle layer (layer 2) generally represents a confined aquifer. Only those cells in the extreme northwest corner, which lie under the inactive (dry) cells of layer 1 , simulate unconfined conditions. The confining bed is not simulated; therefore, the top of layer 2 coincides with the bottom of layer 1 . Because of the lack of data defining the base of the ground-water system, the thickness of layer 2 was not specified; therefore, constant transmissivity had to be used for this layer during all simulations, rather than computing transmissivity from hydraulic conductivity and saturated thickness.

After initial transient simulations, the bottom layer (layer 3) was added in order to provide a source of water for upward leakage into layer 2 . Without this layer, computed water-level declines in layer 1 and layer 2 were almost twice the historical water-level declines. Layer 3 represents a confined aquifer with a constant transmissivity as in layer 2; thus, no top or bottom surfaces had to be specified.

\section{BOUNDARY CONDITIONS}

Boundary conditions during model simulations are of three types: constant head, constant flux, and mixed. Constant-head cells maintain the specified head for the entire simulation. Fluxes entering or leaving the groundwater system through the constant-head cells are calculated based on the head gradient and transmissivity be- tween the boundary and interior cells. Constant-flux cells maintain the specified flux for the entire simulation; the heads are calculated. An impermeable or no-flow boundary can be simulated by constant-flux cells with a specified flux of zero. Mixed boundary conditions are handled by the general-head boundary module in the ground-water flow model of McDonald and Harbaugh (1988, p. 111), wherein the head and flux are calculated at the model boundary using a specified conductance and head at some distance outside the boundary. The conductance can be determined by multiplying the hydraulic conductivity along the flow path from the model boundary to the specified head by the cross-sectional area of the cell at the model boundary and dividing by the length of the flow path. If transmissivity is used instead of hydraulic conductivity, then transmissivity is multiplied by the length of the cell rather than cross-sectional area.

During steady-state calibration, constant-head, constant-flux, and mixed (general-head) cells were used at the boundaries. Constant-head cells were used in layer 1 along recharge boundaries where the estimated head and hydraulic conductivity were considered to be more accurate than any estimate of recharge. As shown in plate 1, constant-head cells were placed along the entire length of the eastern boundary from the north end of the simulated area near Black Rock to south of the Beaver River near Minersville.

Constant-flux cells in layer 1 were placed along boundaries where the potentiometric surface indicated that no appreciable subsurface inflow enters the groundwater system, and were assigned a flux value of zero. This type of boundary condition generally exists along the Black Mountains/basin-fill interface in the south and most of the San Francisco Mountains/basin-fill interface on the west.

The general-head (mixed) boundary was used along two model boundaries where subsurface flow into or out of the basin occurs. This type of boundary was chosen in order to quantify any changes in basin inflow and outflow due to declining water levels during transient simulations. All flow was assumed to enter or leave through layer 2; therefore, cells in layers 1 and 3 along this type of boundary were specified as no-flow. One general-head boundary was placed along the southwest edge where basin inflow enters from the Beryl-Enterprise area. The other general-head boundary was placed along the northwest boundary at the San Francisco Mountains/basin-fill interface and along the north edge of the simulated area near Black Rock. The general-head boundary was not used where interbasin flow enters the basin along Cove Creek and the Beaver River. Because of the small number of cells and the small area involved, any change in head would not make a substantial difference in computed in- 
flow. All boundary cells in layer 2 not specified as general head, and all boundary cells in layer 3 were simulated as no-flow.

\section{INITIAL CONDITIONS}

\section{WATER LEVELS}

Within the area of ground-water development, initial water levels used for steady-state calibration were measured in 1927 and reported by White (1932, p. 58). Additional water levels measured in wells through 1983 were used outside the developed area, where data were few, and at margins of the basin where steady-state conditions were assumed at the time of measurement.

\section{REGHARGE}

Simulated recharge includes subsurface inflow from consolidated rocks, seepage losses from canals and unconsumed irrigation water, infiltration from perennial and ephemeral streams, subsurface inflow from adjoining basins through basin-fill deposits, and precipitation on basin-fill deposits at margins of the basin. On the basis of estimated-head values along the southern and western margins of the basin, no appreciable subsurface inflow enters from the consolidated rocks of the Black Mountains and San Francisco Mountains. Apparently, all subsurface inflow from consolidated rocks is from the Mineral Mountains and from the basalt east of Black Rock. Although this inflow was estimated to be 15,000 acre-ft/yr, the model computed this inflow using a constant-head boundary during steady-state calibration.

Seepage losses from canals and unconsumed irrigation water is another major component of recharge to the ground-water system. Seepage losses from canals, reported by Mower and Cordova (1974, p. 18), vary with the quantity of flow in the canals. On the basis of annual diversions, they reported a weighted average loss of 14 percent of the water diverted in a test reach, or 1.5 percent per mile. This average rate of loss was assumed to apply for the total $23 \mathrm{mi}$ of canals in the area; thus 34 percent of all diversions from the Beaver River is lost. An estimated 4 percent of the loss is assumed to be transpired by vegetation, leaving 30 percent to recharge the ground-water system. The rate of recharge to the ground-water system is thus estimated to be 1.3 percent per mile of canal. This rate, which is used for all major canals, is assumed to be constant for both steady-state and transient conditions despite yearly changes in flow. Losses from major canals were calculated by multiplying 0.013 times the continually decreasing flow for each mile of canal. These losses were then distributed to the appropriate cells based on the length of the canal in a cell. Losses from small canals were assumed to be part of unconsumed water applied to irrigated lands.

The amount of discharge in the Beaver River, which is regulated upstream at the Rocky Ford Dam, determines the distribution for irrigation. By prior rights, the area near Minersville is allocated $13.8 \mathrm{ft}^{3} / \mathrm{s}(10,000$ acre-ft/yr). The remainder of the total discharge is available for use in the area near Milford, up to $21.4 \mathrm{ft}^{3} / \mathrm{s}(15,500$ acre-ft/yr), the maximum quantity that can be transported in the Low Line Canal. Discharge exceeding the total $35.2 \mathrm{ft}^{3} / \mathrm{s}$ $(25,500 \mathrm{acre}-\mathrm{ft} / \mathrm{yr})$ is allowed to flow down the Beaver River channel.

For steady-state calibration, the total 1927 discharge of $31.8 \mathrm{ft}^{3} / \mathrm{s}(23,000$ acre- $\mathrm{ft} / \mathrm{yr}$ ) (Mower and Cordova, 1974, fig. 3) was used. As mentioned above, $13.8 \mathrm{ft}^{3} / \mathrm{s}$ $(10,000 \mathrm{acre}-\mathrm{ft} / \mathrm{yr})$ is allotted to the area near Minersville. Along the 4-mile reach of the Minersville Canal, $0.7 \mathrm{ft}^{3} / \mathrm{s}$ (510 acre-ft/yr) was lost to the ground-water system, thus leaving $13.1 \mathrm{ft}^{3} / \mathrm{s}(9,480$ acre- $\mathrm{ft} / \mathrm{yr})$ for irrigation. Assuming 30 percent infiltration of applied irrigation water, 3.9 $\mathrm{ft}^{3} / \mathrm{s}(2,820$ acre- $\mathrm{ft} / \mathrm{yr})$ infiltrated to the ground-water system and was distributed to cells that cover the currently irrigated area.

After subtracting canal losses of $2.2 \mathrm{ft}^{3} / \mathrm{s}(1,600$ acre$\mathrm{ft} / \mathrm{yr})$ from the $18.0 \mathrm{ft}^{3} / \mathrm{s}(13,000 \mathrm{acre}-\mathrm{ft} / \mathrm{yr})$ diverted into the Low Line Canal, the amount of Beaver River water available for irrigation in the area near Milford was 15.8 $\mathrm{ft}^{3} / \mathrm{s}\left(11,400\right.$ acre-ft/yr), of which $4.7 \mathrm{ft}^{3} / \mathrm{s}(3,400$ acre$\mathrm{ft} / \mathrm{yr}$ ) infiltrated to the ground-water system. This water was divided among cells that coincide with lands irrigated with surface water as shown by Nelson (1950, fig. 11).

Seepage from irrigated lands using ground water was assumed to be 30 percent as suggested by Mower and Cordova $(1974$, p. 21). White $(1932$, p. 88$)$ reported 6.9 $\mathrm{ft}^{3} / \mathrm{s}(5,000$ acre-ft / yr) of ground water was used for irrigation in 1927, of which 30 percent or $2.1 \mathrm{ft}^{3} / \mathrm{s}(1,500$ acre$\mathrm{ft} / \mathrm{yr}$ ) was assumed to be recharge. This seepage was applied by using the distribution shown by White (1932, fig. 2).

Stream infiltration from the Beaver River is a minor source of recharge except in wet years, when the flow downstream from Rocky Ford Reservoir is substantially greater than the $35.2 \mathrm{ft}^{3} / \mathrm{s}(25,500$ acre- $\mathrm{ft} / \mathrm{yr})$ diverted for irrigation. Winter minimum flows are $5 \mathrm{ft}^{3} / \mathrm{s}$ or less as reported by Nelson (1950, p. 185). For steady-state simulation purposes, an average of $2.1 \mathrm{ft}^{3} / \mathrm{s}(1,500 \mathrm{acre}-\mathrm{ft} / \mathrm{yr})$ is assumed to infiltrate to the ground-water system and is distributed along $5 \mathrm{mi}$ of river channel.

All recharge from stream and canal losses and seepage from irrigated lands was simulated as recharging wells with a fixed flux. Stream and canal losses were not 
simulated as head dependent because water levels are below the streambeds or canals.

Subsurface inflow from the Beryl-Enterprise area was computed during model simulations using the generalhead boundary module of McDonald and Harbaugh (1988, p. 11-1). This inflow increased during transient simulations when water-level declines extended to the boundary.

Recharge from precipitation was simulated using the recharge module (McDonald and Harbaugh, 1988, p. 7-1) in the eastern part of the basin where precipitation is greater than 10 inches/yr. Only 5 percent of the precipitation is assumed to infiltrate to the ground-water system because of high evaporation rates and consumption by vegetation. Recharge from precipitation is estimated to be $5.1 \mathrm{ft}^{3} / \mathrm{s}(3,700$ acre-ft/yr), which is greater than the 2.8 $\mathrm{ft}^{3} / \mathrm{s}(2,000$ acre-ft/yr) reported by Mower and Cordova (1974, p. 21). Recharge for each cell was entered as $\mathrm{ft}^{3} / \mathrm{s}$ per $\mathrm{ft}^{2}$ of area, or $\mathrm{ft} / \mathrm{s}$ for each cell.

\section{DISCHARGE}

Initial discharge from the ground-water system was simulated as evapotranspiration, withdrawal from wells, and basin outflow through the northwest general-head boundary. Evapotranspiration was simulated in cells where the water table is within $30 \mathrm{ft}$ of land surface. Using this extinction depth, the area simulating evapotranspiration (pl. 2) corresponds to the phreatophyte area mapped by Mower and Cordova (1974, pl. 3). A maximum evapotranspiration rate is assigned to each cell within the phreatophyte area. The computed evapotranspiration is based on a linear proportion of the maximum rate and the depth of water below land surface at each cell (McDonald and Harbaugh, 1984, p. 317). Evapotranspiration rates used during model simulations ranged from 8.2 $x 10^{-9} \mathrm{ft} / \mathrm{s}$ ( 3 inches $\left./ \mathrm{yr}\right)$ to $9.8 \times 10^{-8} \mathrm{ft} / \mathrm{s}(37$ inches $/ \mathrm{yr})$. These rates are similar to the rates determined by White (1932, p. 86).

Ground-water withdrawal from wells was estimated by White $(1932$, p. 88$)$ to be 5,000 acre-ft for 1927 . The areal distribution for withdrawal from wells determined by White (1932, fig. 2) was used for steady-state calibration.

Basin outflow to the northwest was calculated during steady-state simulations using a general-head boundary. By calibrating computed heads to estimated heads and assuming the estimated distribution of transmissivity approximates reality, a reasonable estimate for basin outflow can be determined.

\section{HYDRAULIC CONDUCTIVITY}

Horizontal hydraulic-conductivity values for the upper water-table layer (layer 1) were estimated from drillers' logs using a weighted average for all lithologies, and from specific capacities determined from tests conducted at time of drilling. These hydraulic-conductivity values are multiplied by the saturated thickness in each cell during model computations. Hydraulic-conductivity values range from $2.3 \times 10^{-5} \mathrm{ft} / \mathrm{s}(2 \mathrm{ft} / \mathrm{d})$ to $6.9 \times 10^{-4} \mathrm{ft} / \mathrm{s}(60$ $\mathrm{ft} / \mathrm{d}$ ) and were changed by trial-and-error during steadystate calibration. The middle layer (layer 2) was simulated as a confined-unconfined aquifer using a constant transmissivity rather than calculating transmissivity from the saturated thickness. Transmissivity values in layer 2 range from $9.3 \times 10^{-3} \mathrm{ft}^{2} / \mathrm{s}\left(800 \mathrm{ft}^{2} / \mathrm{d}\right)$ to $5.4 \times 10^{-1} \mathrm{ft}^{2} / \mathrm{s}$ $\left(47,000 \mathrm{ft}^{2} / \mathrm{d}\right)$ and were similar to the distribution reported by Mower and Cordova (1974, fig. 4). The bottom layer was simulated as a confined system. Hydraulic properties of this layer are unknown because this part of the aquifer lies below the level of present development. Transmissivity values were arbitrarily assumed to be onethird of those used in the middle layer.

Most irrigation wells in the Milford area are completed in multiple permeable zones, thus maximizing production. The lack of wells with completion in a specific zone limits the ability to determine vertical hydraulic conductivity and vertical head gradient. For this reason, no estimates of vertical hydraulic conductivity and vertical head gradient were reported by Mower and Cordova (1974) and no aquifer tests were designed to determine vertical hydraulic conductivity during this study. From limited water-level data representative of specific zones, the difference in head between the water-table or semiconfined aquifer (layer 1) and the underlying confined aquifer (layer 2) was estimated to range from 1 to $10 \mathrm{ft}$ in the center of the basin.

The model calculates vertical flow between layers from data incorporating vertical hydraulic conductivity and aquifer thickness. The resulting term, known as vertical leakance (McDonald and Harbaugh, 1988, p. 5-12), is calculated by dividing the estimated vertical hydraulic conductivity by the distance between the centers of adjoining model layers. Vertical hydraulic conductivity can be assumed to be one to two orders of magnitude smaller than horizontal hydraulic conductivity. Although the model was designed with unspecified thicknesses for layers 2 and 3 , the distance between the centers of adjoining model layers can be assumed to be a few hundred feet. Initial vertical leakance between layers, therefore, was estimated to range between 1.0 to $5.0 \times 10^{-9} / \mathrm{s}\left(8.6 \times 10^{-5}\right.$ to $\left.4.3 \times 10^{-4} / \mathrm{d}\right)$. The larger values were distributed at the basin margin where vertical leakage is larger than in the center of the basin. These values were adjusted during 
calibration to maintain the estimated head differences between layers 1 and 2.

\section{STORAGE GOEFFICIENTS}

An average value of 0.20 for specific yield as reported by Mower and Cordova $(1974$, p. 15) was used for the entire upper layer (layer 1). In the middle layer (layer 2), two storage-coefficient arrays are necessary because it is simulated as a confined-unconfined system. The primary array contains the storage-coefficient values for the confined aquifer that range from $5.0 \times 10^{-4}$ to $1.5 \times 10^{-3}$. The secondary storage-coefficient array is necessary when cells in layer 1 become dry and the underlying cells in layer 2 simulate an unconfined aquifer. Because of greater compaction at depth, the secondary storage-coefficient array was assigned an average value of 0.10 . The bottom layer (layer 3 ) is confined throughout the simulated area and was assigned values an order of magnitude less than the primary storage-coefficient array for layer 2 .

\section{STEADY-STATE CALIBRATION}

The model was first calibrated to steady-state heads known to exist prior to large-scale ground-water development. Hydraulic conductivity and transmissivity in all layers were varied along with vertical leakance during steady-state calibration to obtain a best fit to initial heads. Evapotranspiration rates also were adjusted to get a better match to initial heads; however, all adjusted values remained within the initial ranges.

In the calibration process, the vertical leakance values between layers were adjusted so that the estimated head differences between layers 1 and 2 were maintained and the necessary quantity of water from layer 3 moved upward. Calibrated vertical leakance values between layers 1 and 2 range from $4.8 \times 10^{-10}$ to $6.1 \times 10^{-8} / \mathrm{s}\left(4.1 \times 10^{-5}\right.$ to $5.3 \times 10^{-3} / \mathrm{d}$ ). Calibrated vertical leakance values between layers 2 and 3 range from $1.2 \times 10^{-9}$ to $7.2 \times 10^{-8} / \mathrm{s}(1.0 \mathrm{x}$ $10^{-4}$ to $6.2 \times 10^{-3} / \mathrm{d}$ ).

Initial conductance values were varied at both general-head boundaries. At the southwestern boundary, the conductances were varied to match computed heads and fluxes to known heads and to the total estimated subsurface inflow of $2.9 \mathrm{ft}^{3} / \mathrm{s}(2,100$ acre- $\mathrm{ft} / \mathrm{yr}$ ) (Mower, 1982, p. 47). At this boundary, the final conductances range from $4 \times 10^{-3}$ to $2.5 \times 10^{-2} \mathrm{ft}^{2} / \mathrm{s}$ (345 to $2,160 \mathrm{ft}^{2} / \mathrm{d}$ ). Through this process, the computed steady-state heads were within $20 \mathrm{ft}$ of the initial heads estimated from field data and the total computed subsurface inflow was only $0.2 \mathrm{ft}^{3} / \mathrm{s}$ (145 acre-ft/yr) below the initial estimate.
Because no estimate had ever been made for subsurface outflow along the northwestern general-head boundary, the conductances were varied in order to match estimated heads in the boundary cells. Most of the computed heads were within $30 \mathrm{ft}$ of the estimated heads in this area; a $65-\mathrm{ft}$ difference was the largest deviation. These computed heads are considered to be within calibration limits given that the estimated head gradient is greater than $100 \mathrm{ft} / \mathrm{mi}$, which is based on very limited data and large cell size in this area. The model-calculated, steady-state subsurface outflow for this boundary is 15.8 $\mathrm{ft}^{3} / \mathrm{s}(11,400$ acre- $\mathrm{ft} / \mathrm{yr})$. In most cases, the conductance for each cell was increased by three times the original estimate. The final conductances at the northwest boundary range from $1 \times 10^{-3}$ to $4 \times 10^{-2} \mathrm{ft}^{2} / \mathrm{s}\left(86\right.$ to $\left.3,460 \mathrm{ft}^{2} / \mathrm{d}\right)$.

Steady-state calibration criteria included a match to within $5 \mathrm{ft}$ of initial heads in the area of ground-water development and a reasonable match in other areas depending on hydraulic gradient, topography, and quantity of data. Within a 309-cell area, where sufficient data were available to make a reasonable estimate of steady-state water levels or where the estimated hydraulic gradient was small, the average difference between initial head and computed head was less than $2 \mathrm{ft}$ for all three layers. Along most of the margins of the basins, a match to within $20 \mathrm{ft}$ was considered to be within calibration limits. In a few areas, such as the southeast recharge area near Minersville and in the northwestern outflow area, the difference between initial and computed heads was greater than $20 \mathrm{ft}$. This can be attributed to the steep hydraulic gradient, large cell size, and uncertainty in estimated initial heads.

Recharge from consolidated rocks was simulated by using constant-head cells along the eastern boundary of the area. The steady-state calibrated model is just one of many possible solutions because recharge is unbounded. The calibrated model, however, is a reasonable approximation of the ground-water system under steady-state conditions because hydraulic conductivity was varied within reasonable limits along this boundary in order to match initial heads. The original estimate for recharge from consolidated rocks was calculated to be $20.7 \mathrm{ft}^{3} / \mathrm{s}$ $(15,000 \mathrm{acre}-\mathrm{ft} / \mathrm{yr})$. By not assigning this recharge as constant flux along this boundary, the model calculated the recharge to be $32.9 \mathrm{ft}^{3} / \mathrm{s}(23,800$ acre-ft/yr).

Computer-generated steady-state contours for initial and computed heads in layers 1 and 2 are shown in figures 8 and 9. The similarity in the figures is due to the relatively small head differences between the two layers, except in the center of the basin, where estimated head differences are assumed to be 1 to $10 \mathrm{ft}$.

Prior to transient calibration, all constant-head cells along the eastern boundary of the simulated area were 


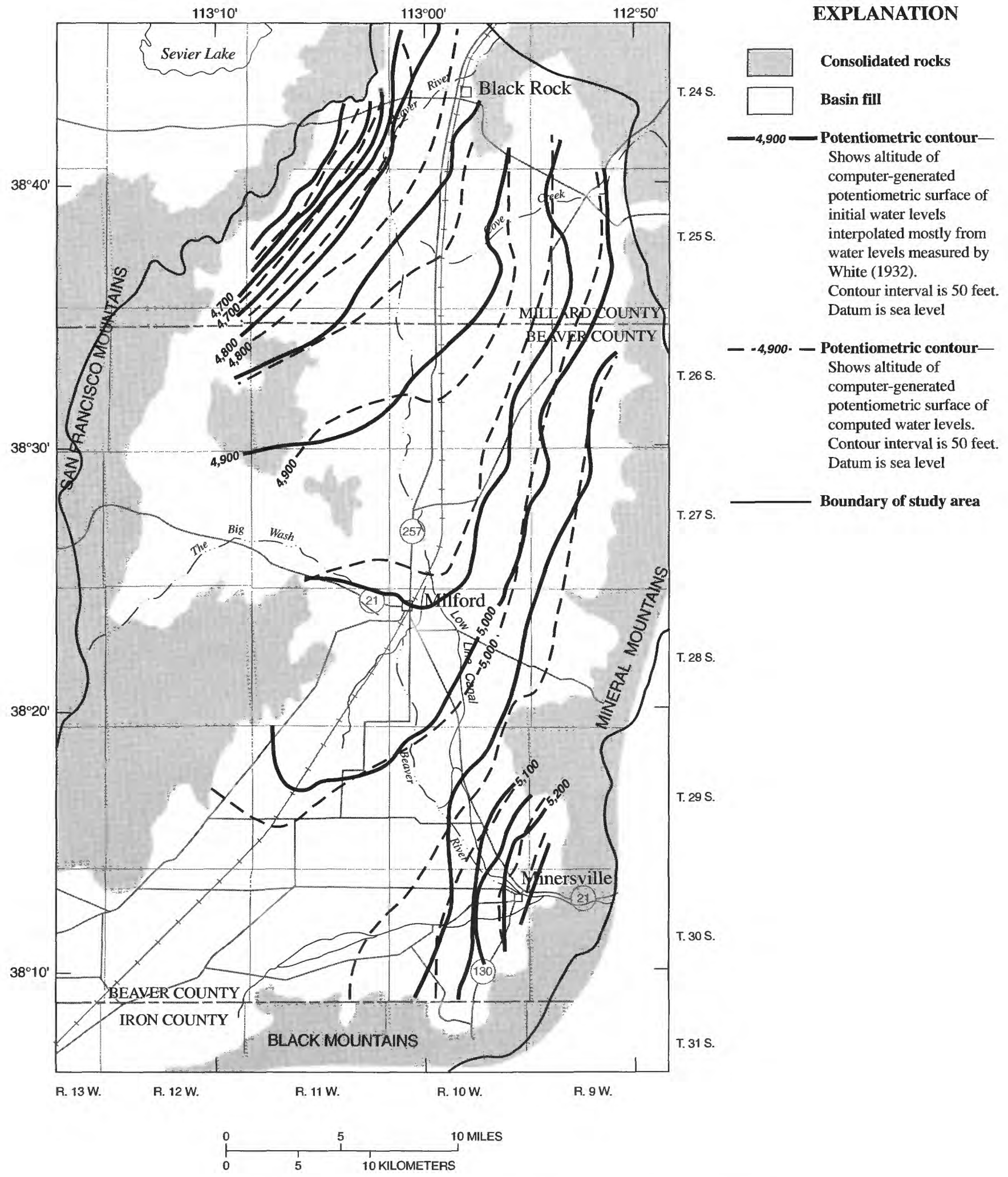

FIGURE 8.-Steady-state contours for initial and computed water levels in layer 1. 


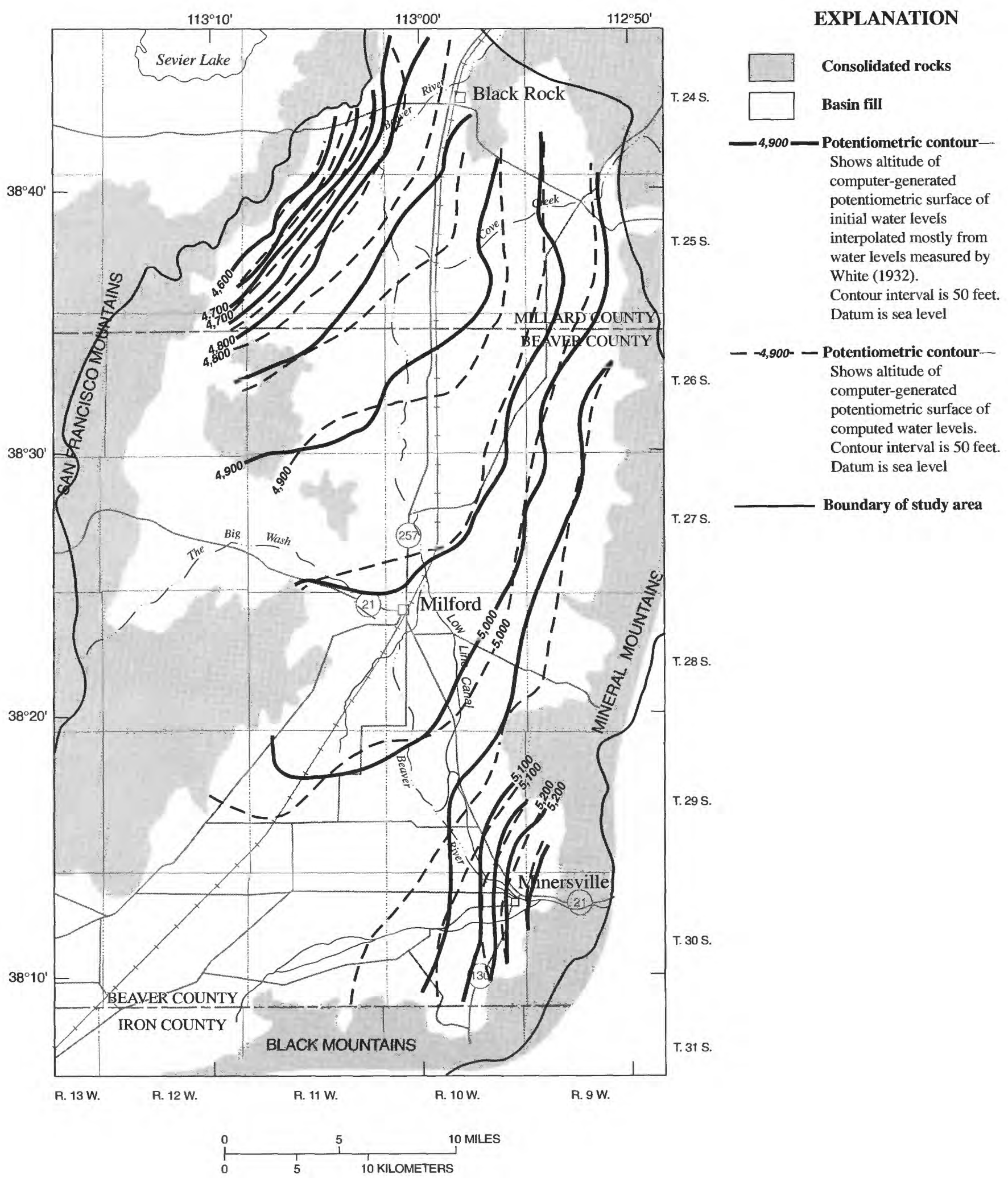

FIGURE 9.-Steady-state contours for initial and computed water levels in layer 2. 
converted to constant-flux cells with all model-calculated fluxes entered into the same recharge array as infiltration from precipitation. As a transition step from steady-state to transient calibration, arrays containing the necessary storage-coefficient values were entered and a 100-year simulation was made using steady-state conditions. This simulation verified that the model-calculated boundary fluxes did not vary with time.

\section{TRANSIENT GALIBRATION}

Transient calibration involved the use of time-dependent data such as storage, known ground-water withdrawals, and varying seepage from the Beaver River channel and irrigated lands. Storage was adjusted in order to match known water-level fluctuations. Steadystate conditions were assumed to have prevailed in the Milford area until 1950 when ground-water withdrawals began to increase rapidly. Withdrawals varied from 15.0 $\mathrm{ft}^{3} / \mathrm{s}(10,900 \mathrm{acre}-\mathrm{ft} / \mathrm{yr})$ to $31.5 \mathrm{ft}^{3} / \mathrm{s}(22,800$ acre-ft/yr) during 1931-49. After 1950, withdrawals did not drop below $44.2 \mathrm{ft}^{3} / \mathrm{s}(32,000$ acre-ft/yr) (fig. 6). Coincident with this increase, water levels in observation wells (C-29-10)6ddc-1 and (C-29-10)6ddc-2 began to decline after 1950 (fig. 7). The model-calculated, steady-state heads were assumed to be representative of the ground-water system prior to 1950 and were used as initial heads for transient calibration.

Seven pumping or stress periods were selected for the transient calibration: 1950-52, 1953-60, 1961-67, 1968-72, 1973, 1974-78, and 1979-82. During these intervals, discharge from wells was relatively constant. The fifth stress period, 1973, was a year of high flows in the Beaver River and decreased pumping. By defining a single-year stress period, the model could be tested for its response to increased recharge and decreased ground-water withdrawals. Water-level changes were computed for the end of each stress period within the 33-year transient-simulation period, starting from the calibrated, steady-state water levels. The computed changes in water levels for each stress period were compared to water-level changes calculated from measurements made in March of the year after each stress period.

Differences between measured and computed waterlevel changes may reflect the response of the aquifer to a large change in the last year of a stress period rather than the overall trend for the entire stress period. Also, in some observation wells, the measured water levels are representative of both the unconfined and confined aquifers, depending on the location of the perforated intervals; whereas computed water levels are representative of either the unconfined or confined aquifers, depending on location and model layer.

The average ground-water withdrawals applied during each stress period are shown in table 1. Annual ground-water withdrawals for each well were averaged over each stress period. If a well penetrated more than one model layer, the average withdrawal was divided proportionally between the layers based on the percent of perforated interval in each layer. Finally, average withdrawals for all wells were combined for each cell in a model layer.

Two simulations were made for the transient calibration, each treating recharge from seepage to the groundwater system differently. In both cases, seepage was based on the mean annual flow in the Beaver River as measured at Rocky Ford Dam. For the first transient simulation, seepage from surface-water irrigation, canal losses, and infiltration from the Beaver River were averaged for each stress period. As mentioned previously, the 13.8 $\mathrm{ft}^{3} / \mathrm{s}(10,000 \mathrm{acre}-\mathrm{ft} / \mathrm{yr})$ of surface water diverted to the area near Minersville remained constant due to prior rights. In 1960, the flow in the Beaver River was slightly below the amount allocated to the Minersville area (fig.

TABLE 1.-Variation in water-budget components during historical transient simulations in the Milford area, Utah

[Data are in cubic feet per second; acre-feet per year shown in parentheses]

\begin{tabular}{|c|c|c|c|}
\hline \multirow{2}{*}{$\begin{array}{c}\text { Stress } \\
\text { period } \\
\text { (years) }\end{array}$} & \multirow{2}{*}{$\begin{array}{l}\text { Ground-water } \\
\text { withdrawals }\end{array}$} & \multicolumn{2}{|c|}{$\begin{array}{l}\text { Recharge from seepage to } \\
\text { ground-water system }\end{array}$} \\
\hline & & Variable $^{2}$ & Constant $^{3}$ \\
\hline $1950-52$ & $\begin{array}{c}42.8 \\
(31,000)\end{array}$ & $\begin{array}{c}30.4 \\
(22,000)\end{array}$ & $\begin{array}{c}26.4 \\
(19,100)\end{array}$ \\
\hline $1953-60$ & $\begin{array}{c}56.5 \\
(40,900)\end{array}$ & $\begin{array}{c}28.6 \\
(20,700)\end{array}$ & $\begin{array}{c}30.5 \\
(22,100)\end{array}$ \\
\hline $1961-67$ & $\begin{array}{c}61.5 \\
(44,500)\end{array}$ & $\begin{array}{c}27.4 \\
(19,800)\end{array}$ & $\begin{array}{c}32.0 \\
(23,200)\end{array}$ \\
\hline $1968-72$ & $\begin{array}{c}74.2 \\
(53,700)\end{array}$ & $\begin{array}{c}39.9 \\
(28,900)\end{array}$ & $\begin{array}{c}35.8 \\
(26,000)\end{array}$ \\
\hline 1973 & $\begin{array}{c}69.0 \\
(50,000)\end{array}$ & $\begin{array}{c}60.6 \\
(43,900)\end{array}$ & $\begin{array}{c}34.2 \\
(24,800)\end{array}$ \\
\hline $1974-78$ & $\begin{array}{c}83.0 \\
(60,100)\end{array}$ & $\begin{array}{c}42.9 \\
(31,100)\end{array}$ & $\begin{array}{c}38.4 \\
(27,800)\end{array}$ \\
\hline $1979-82$ & $\begin{array}{c}63.6 \\
(46,000)\end{array}$ & $\begin{array}{c}51.8 \\
(37,600)\end{array}$ & $\begin{array}{c}32.6 \\
(23,600)\end{array}$ \\
\hline
\end{tabular}

\footnotetext{
${ }^{1}$ Sum of seepage from irrigated lands using surface and ground water, canal losses, and infiltration from the Beaver River.

${ }^{2}$ Based on the mean annual flow in the Beaver River and associated canals during each stress period.

${ }^{3}$ Based on the mean annual flow in the Beaver River and associated canals during the entire simulation period.
} 
3); however, the mean annual flow for any one stress period was never lower than that allocation.

A ratio was calculated by which the seepage in the area near Milford was adjusted for each stress period. The diversion to the area near Minersville was subtracted from the mean annual flow in the Beaver River as measured at Rocky Ford Dam. The remaining flow, up to a maximum of $21.4 \mathrm{ft}^{3} / \mathrm{s}(15,500$ acre- $\mathrm{ft} / \mathrm{yr})$, was divided by the flow that was diverted to the area near Milford in the steady-state calibration. This ratio was then multiplied by the steady-state seepage for each affected cell, thus increasing or decreasing the seepage for each stress period from the steady-state seepage. The same distribution of surface-water irrigated lands was used for each stress period. If the mean annual flow in the Beaver River was in excess of the $35.2 \mathrm{ft}^{3} / \mathrm{s}(25,500$ acre- $\mathrm{ft} / \mathrm{yr})$ diverted for irrigation in any stress period, then the entire amount of excess flow was assumed to recharge the ground-water system and was distributed among the cells along the Beaver River channel.

A second simulation was made in which one set of average values was used for seepage to the ground-water system during the entire simulation period rather than a different set of values for each stress period. In this simulation, seepage to the ground-water system in the area near Minersville remained the same as in the previous simulation.

Seepage from land irrigated with ground water was simulated for each stress period by assuming that 30 percent of the water withdrawn from each cell returned to the ground-water system. Because this type of recharge is independent of the surface-water system, the percentage of seepage remained constant for each transient simulation. Computer-generated contours of computed water levels for 1983, at the end of the transient simulation using constant recharge, are reasonably close to water levels measured in wells for that year (fig. 10).

Differences in simulated water levels for the two transient simulations using constant and varying recharge from seepage for each stress period are considered to be substantial if greater than $2 \mathrm{ft}$. These differences are found in or near areas of recharge from seepage of surface water as shown in figure 11. Measured and computed water-level changes for 13 observation wells that have data for most or all of the stress periods are shown in figure 12. These observation wells are located in the north and west parts of the developed area where the effects of seepage from surface-water irrigation are negligible; therefore, only computed water-level changes using constant recharge are compared to measured water-level changes. Measured and computed water-level changes for seven observation wells in which there are some, but minimal, differences are shown in figure 13. Simulated water-level changes for three observation wells where there are substantial differences between the two types of computed water-level changes are shown in figure 14. These observation wells are located in the southeastern part of the developed area, closest to the area of surfacewater recharge. The computed water levels from the transient simulation using constant seepage from surfacewater irrigation show a steady decline. This decline might be the result of withdrawals in the main pumping center to the north. By varying the recharge for each stress period, recharge becomes the dominant influence on the ground-water system in this area, although the long-term decline still occurs. The computed water-level changes follow the same trends as those shown by the measured water-level changes; however, overall waterlevel declines obtained from constant recharge show a better match to the total measured declines.

When seepage to the ground-water system from surface-water sources was varied, model-calculated, waterbudget components of evapotranspiration and basin outflow were not substantially different than those calculated when seepage for each stress period was constant (table 2). In the last stress period with varying seepage, however, the large increase in seepage from the Beaver River resulted in a net increase of almost $5 \mathrm{ft}^{3} / \mathrm{s}(3,620$ acre-ft/yr) of water going into storage. In addition, the three observation wells that show substantial water-level changes are located near the Beaver River. This would indicate that the greatest effect on computed water levels is the result of excess flow in the Beaver River channel recharging the ground-water system.

Historical transient simulations using both varying and constant recharge from seepage of surface-water irrigation show water-level declines of nearly $22 \mathrm{ft}$ along the eastern constant-flux boundary; however, limited waterlevel data in this area indicate that there have been no actual water-level declines during the 1950-82 simulation period. Adjusting the constant-flux rates based on the variation from average precipitation for each stress period still gave computed water-level declines of nearly $16 \mathrm{ft}$ along the eastern boundary. The simulated boundary effects are therefore probably due to the grid spacing in this narrow basin and large simulated ground-water withdrawals, rather than the flux rates at the boundary.

\section{SENSITIVITY ANALYSIS}

Numerous simulations were made to determine the sensitivity of the calibrated, steady-state model to changes in input data. Each parameter was increased and decreased by 20 percent of its final calibrated value for all layers simultaneously and for each layer separately. 


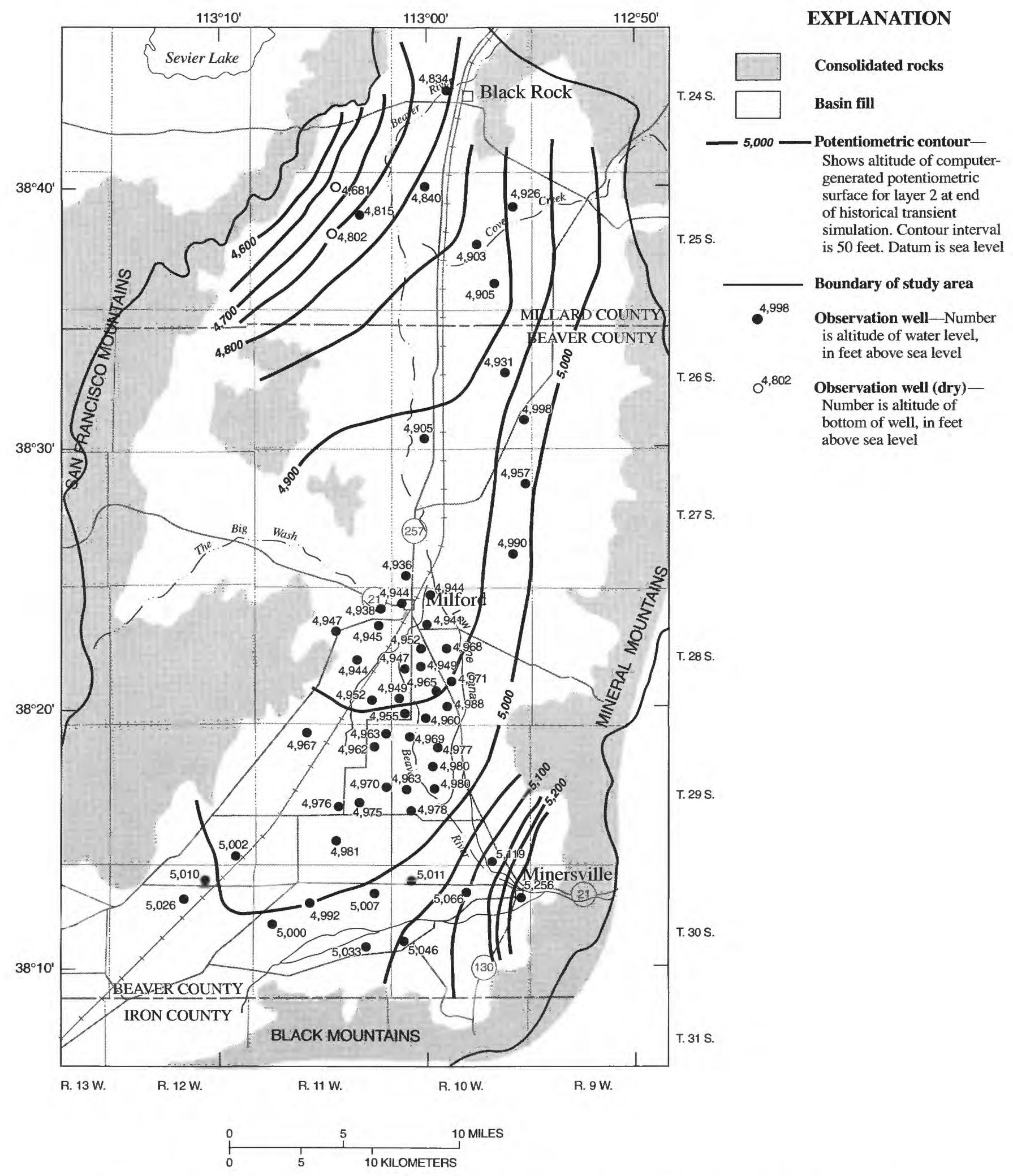

FIGURE 10.-Potentiometric contours for the end of the historical transient simulation for layer 2 using constant recharge from seepage of surface water and measured water levels in wells in March 1983. 


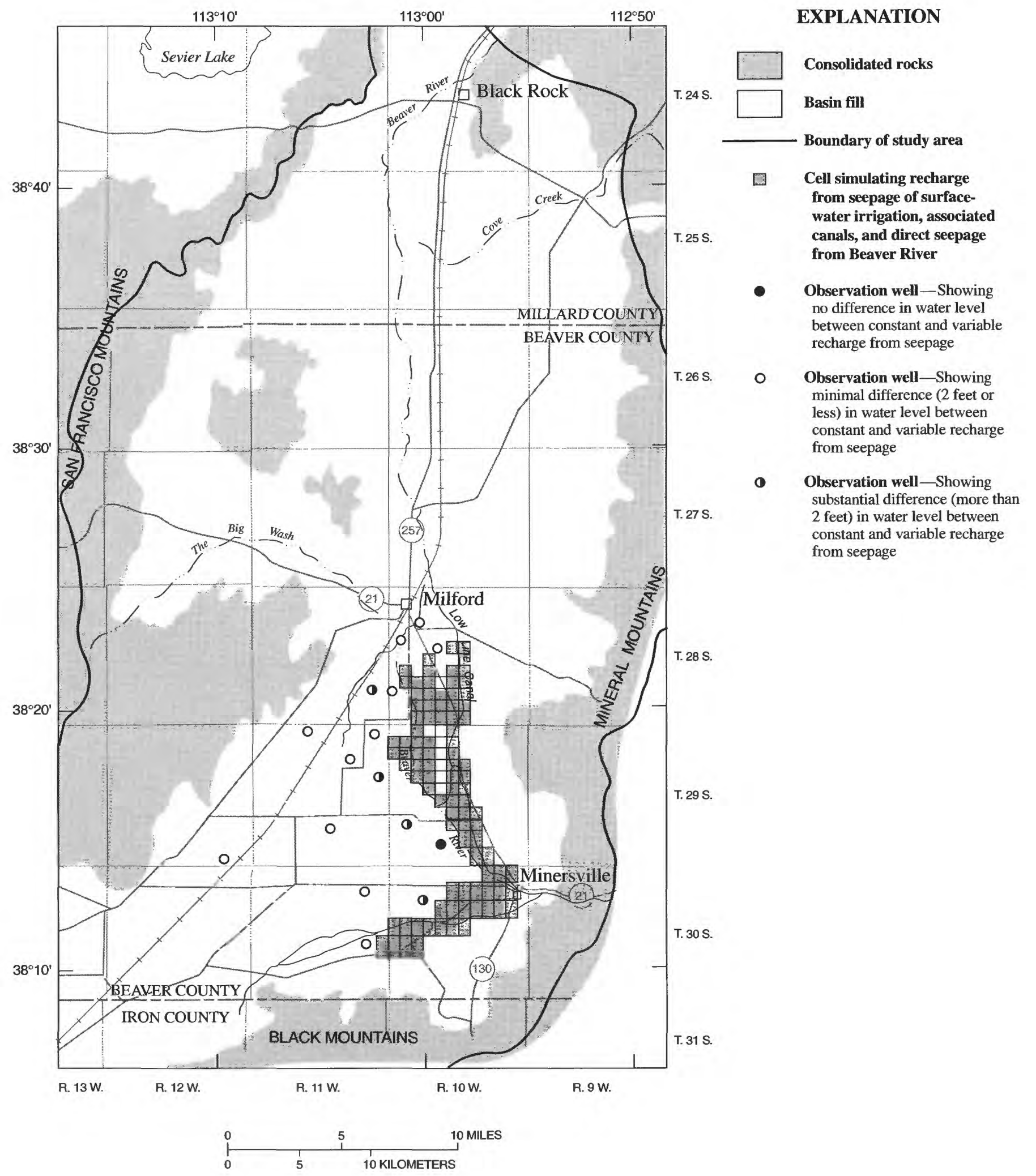

FIGURE 11.-Model cells receiving constant and variable recharge from seepage of surface water during transient simulations and location of observation wells from which measured water levels are compared to computed water levels. 


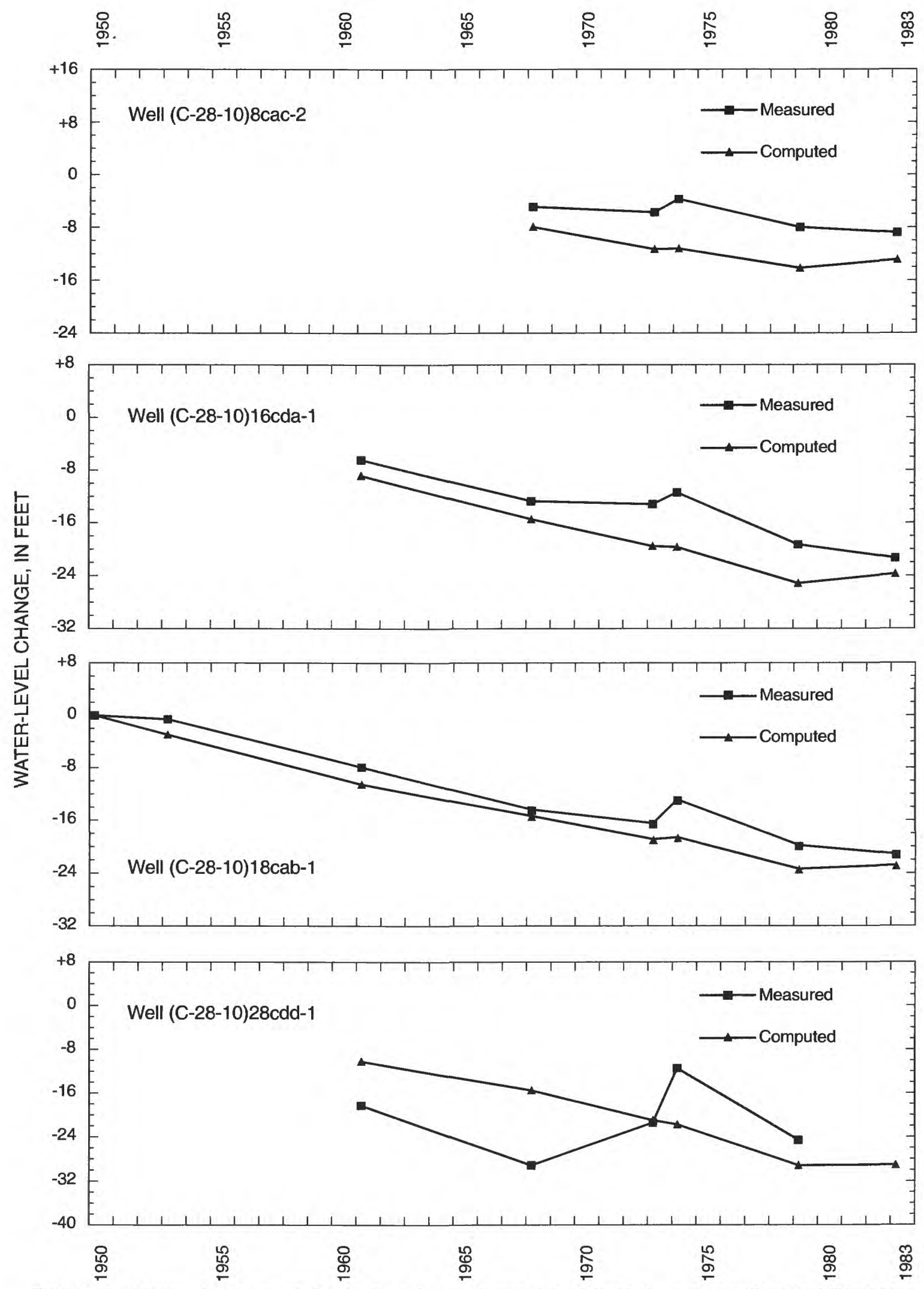

FIGURE 12.-Measured and computed water-level changes during 1950-83 for 13 observation wells in the Milford area. 


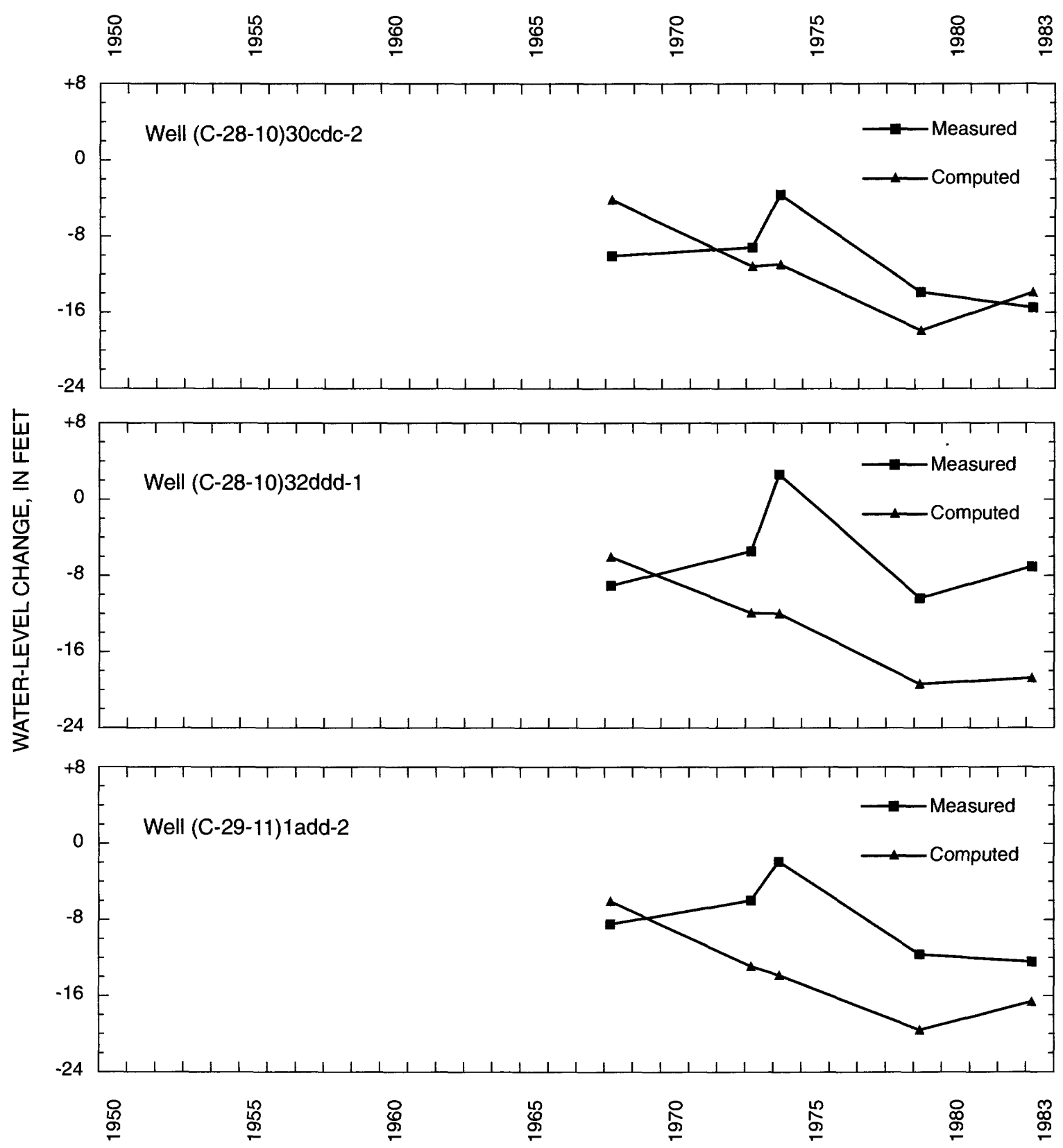

FIGURE 12.-Measured and computed water-level changes during 1950-83 for 13 observation wells in the Milford area-Continued. 


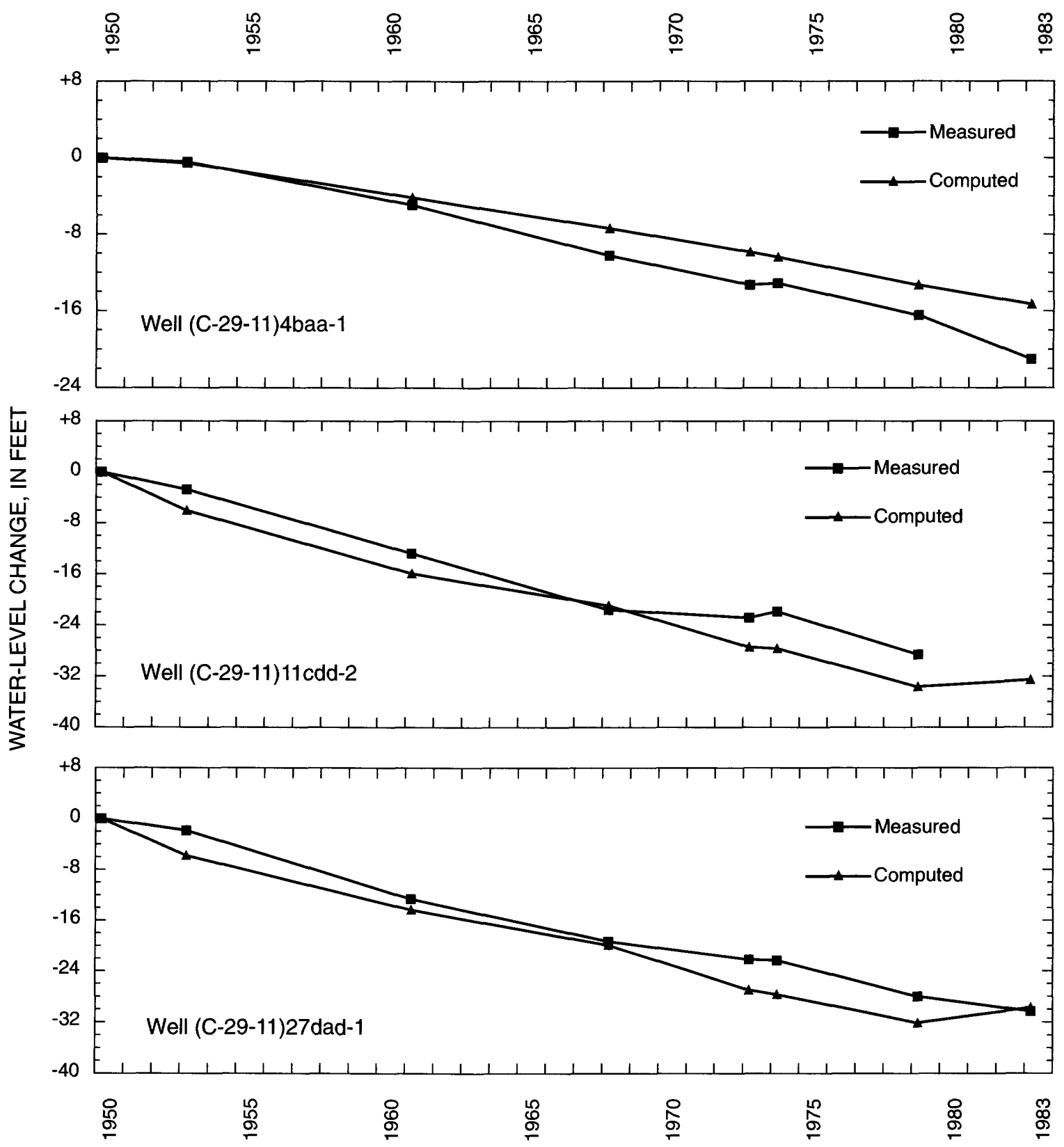

FIGURE 12.-Measured and computed water-level changes during 1950-83 for 13 observation wells in the Milford area-Continued. 


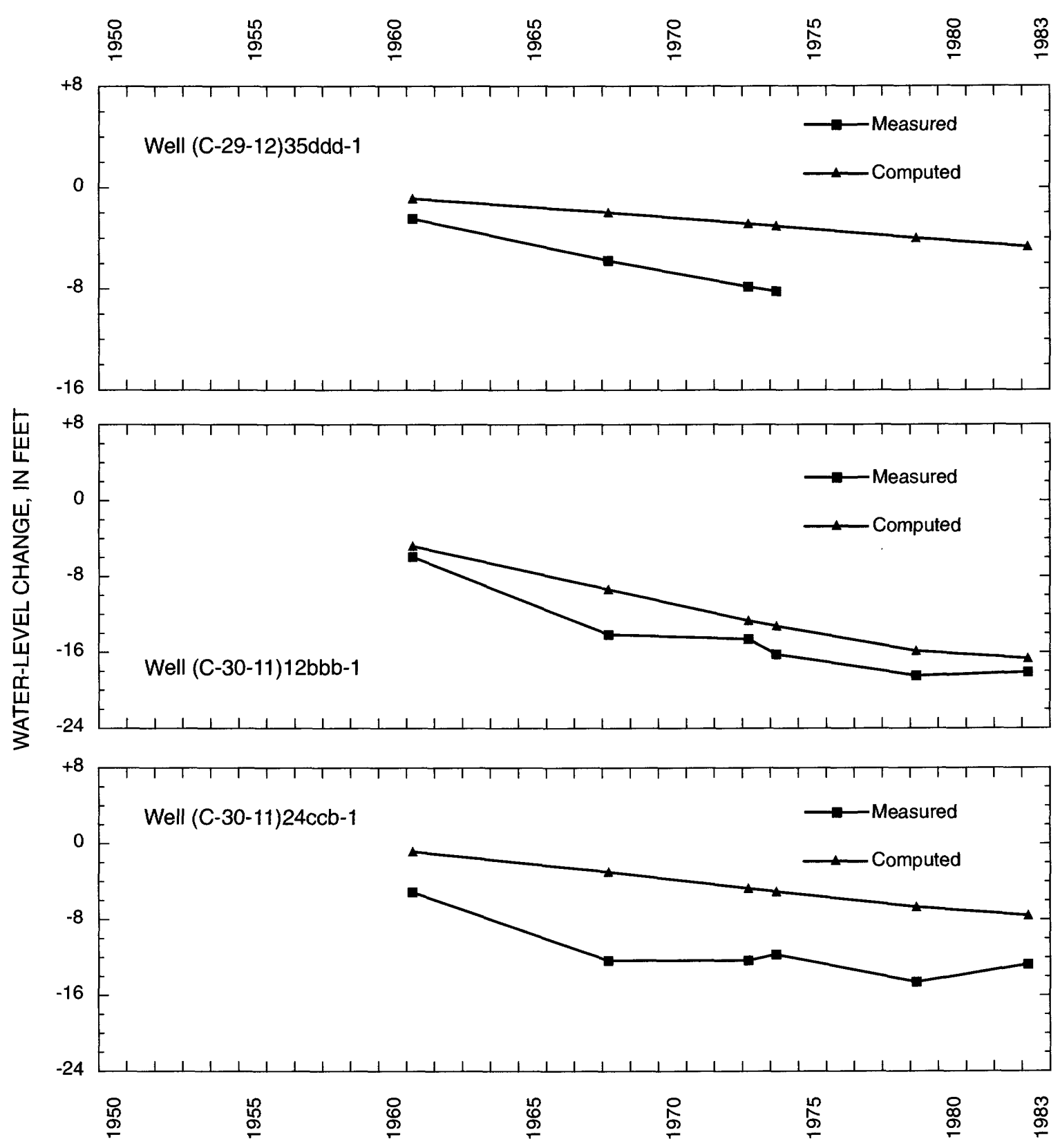

FIGURE 12.-Measured and computed water-level changes during 1950-83 for 13 observation wells in the Milford area-Continued. 


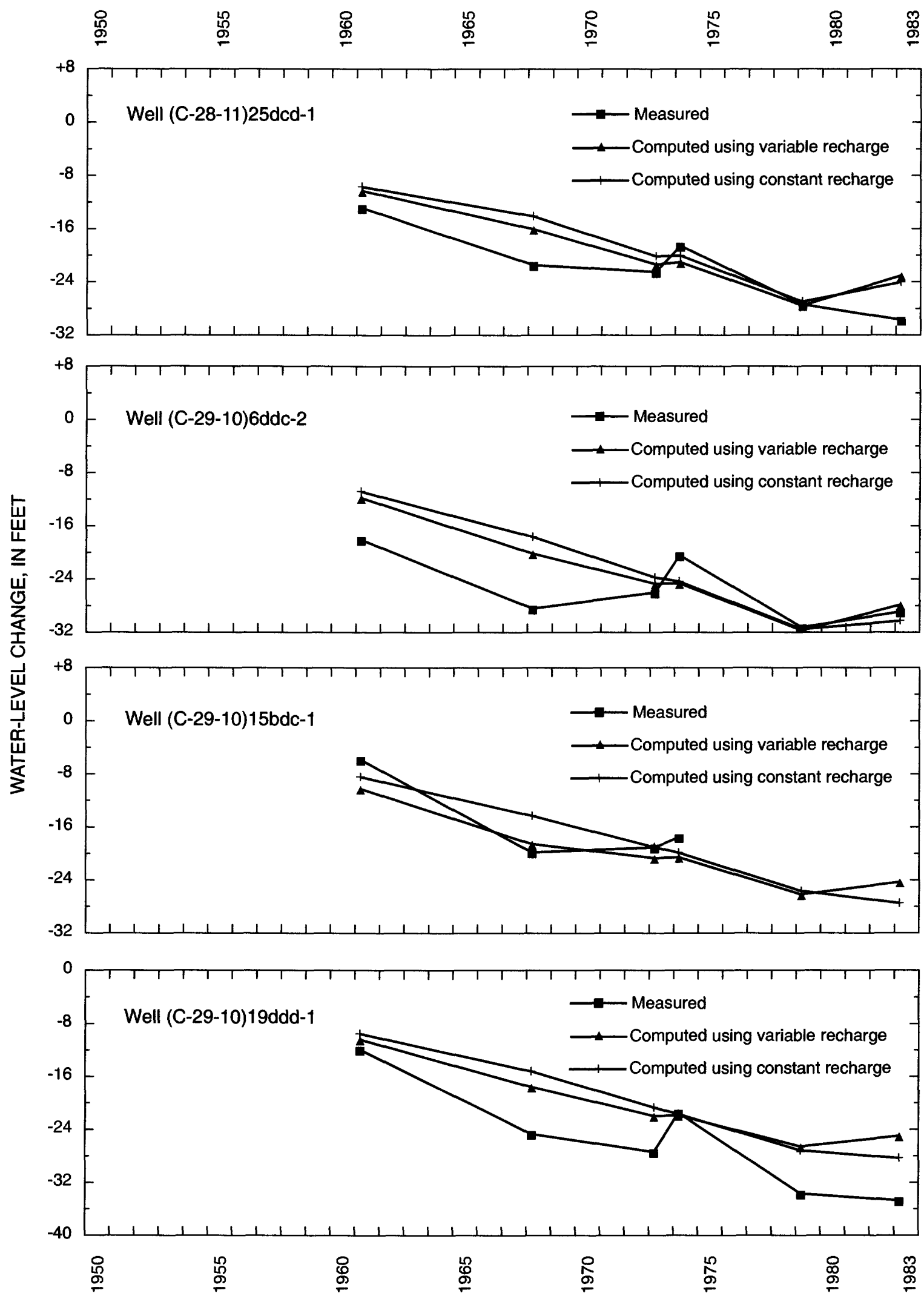

FIGURE 13.-Measured and computed water-level changes during 1950-83 for seven observation wells in the Milford area that show minimal differences ( $2 \mathrm{ft}$ or less) in computed levels between constant and variable recharge from seepage. 


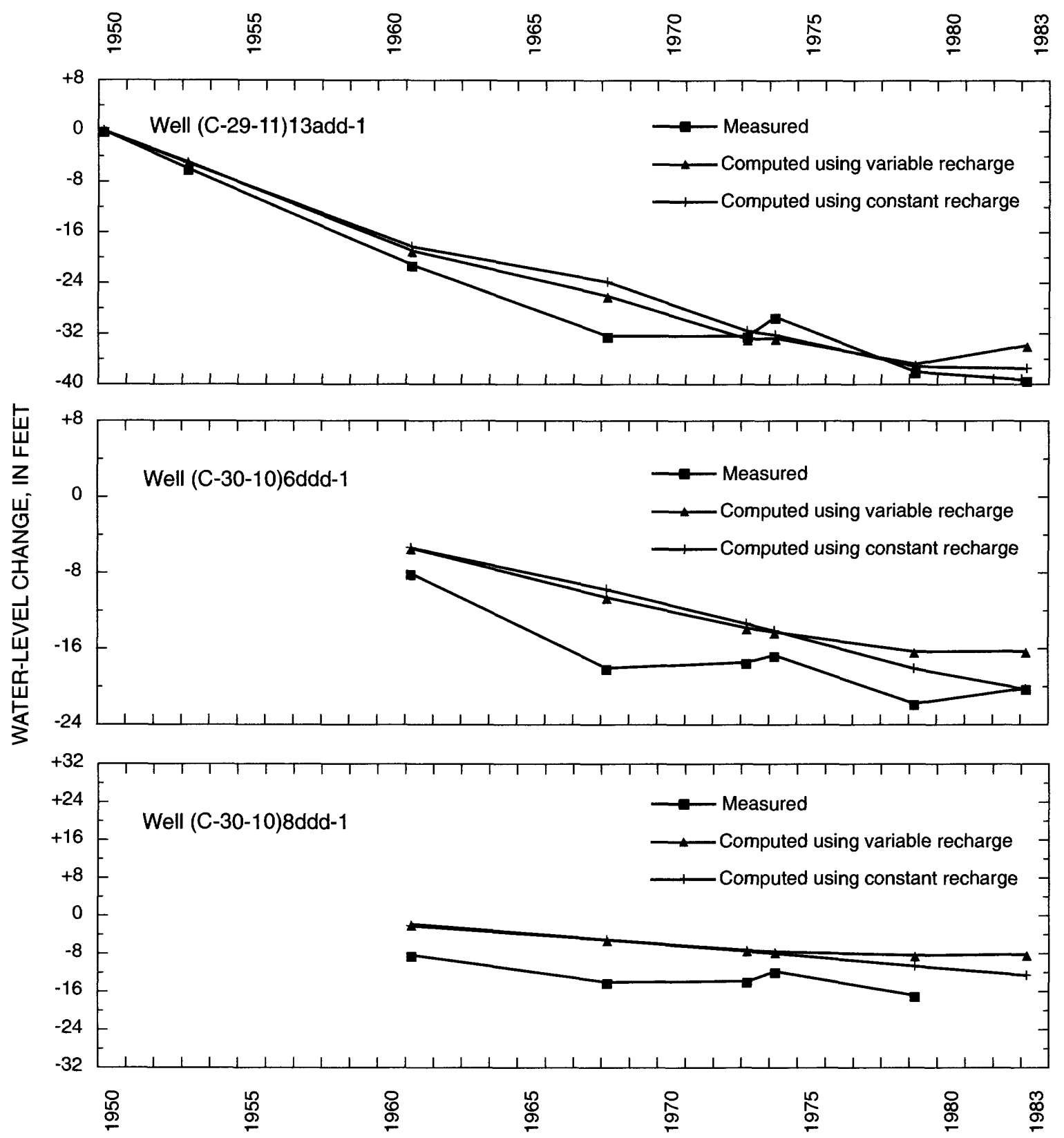

FIGURE 13.-Measured and computed water-level changes during 1950-83 for seven observation wells in the Milford area that show minimal differences ( $2 \mathrm{ft}$ or less) in computed levels between constant and variable recharge from seepage-Continued. 


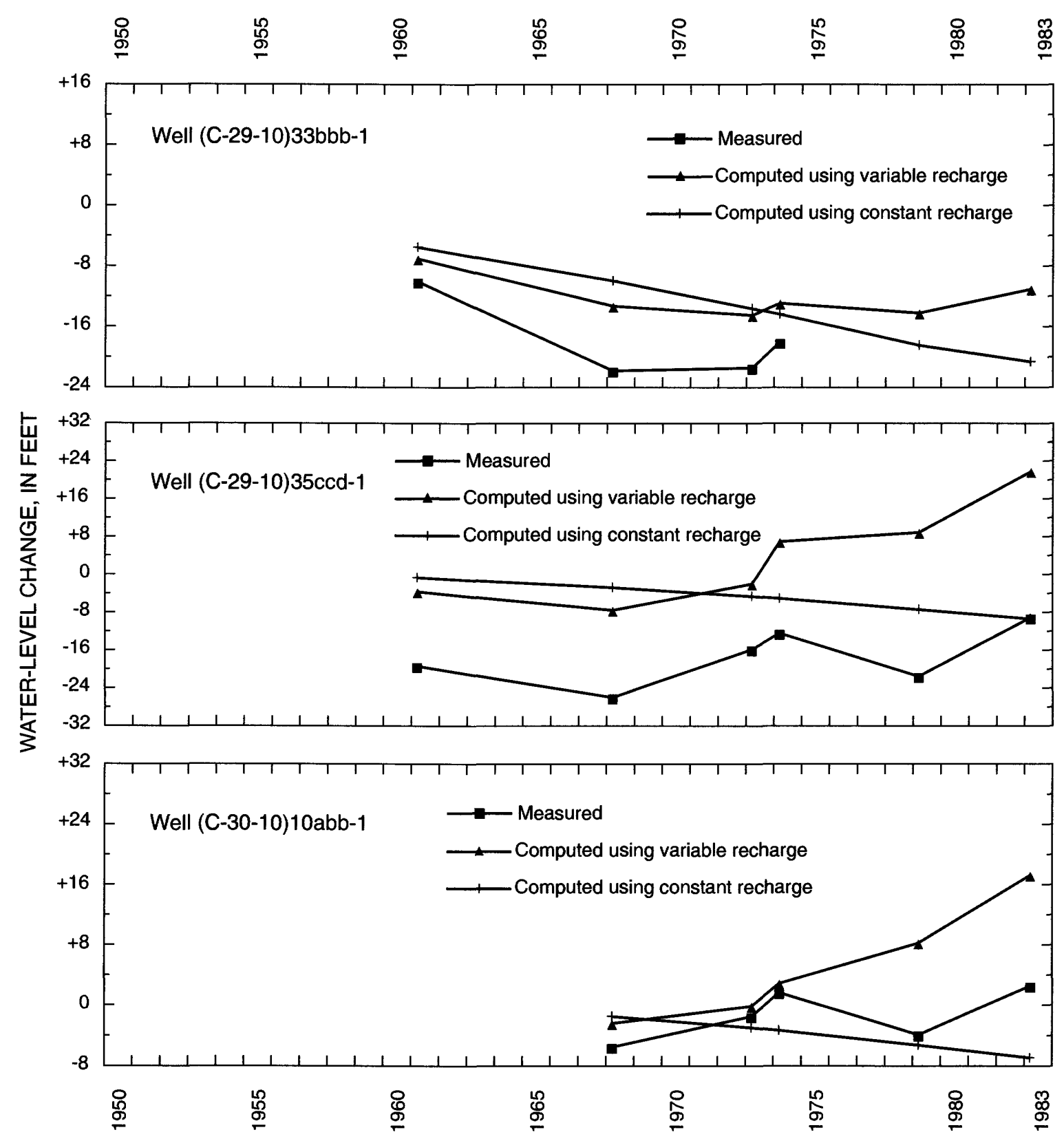

FIGURE 14.-Measured and computed water-level changes during $1950-83$ for three observation wells in the Milford area that show substantial differences (more than $2 \mathrm{ft}$ ) in computed levels between constant and variable recharge from seepage. 
TABLE 2.-Simulated steady-state (1927) and transient-state (1979-82) ground-water budget for the Milford area, Utah [Data are in cubic feet per second; acre-feet per year shown in parentheses. Dashes (-) indicate not applicable]

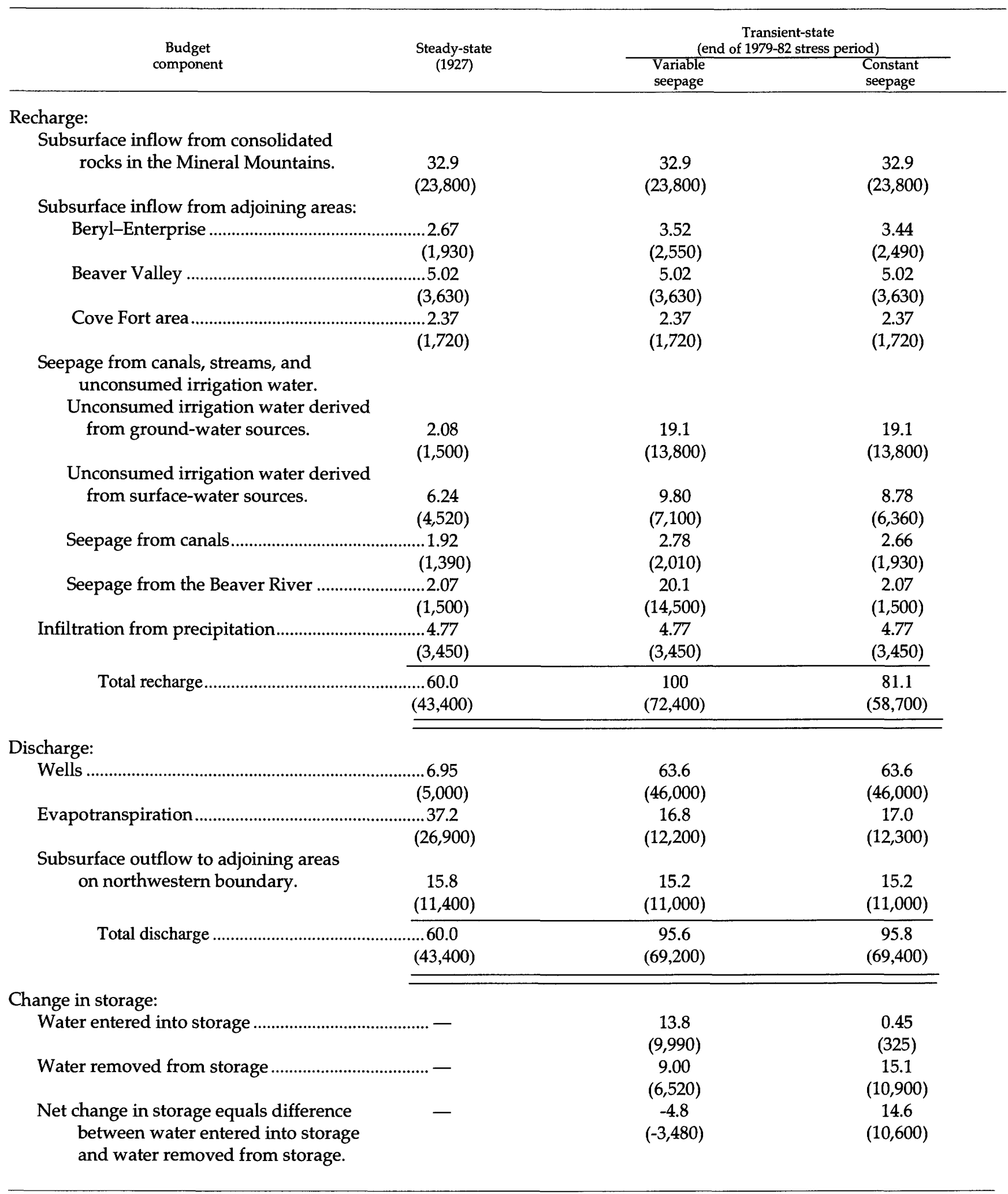


These changes are considered to be a reasonable estimate of error for each parameter, although the estimate of error may be much greater in areas with few data. After each simulation, the average difference between computed and calibrated steady-state heads was determined for each layer in a 309-cell area (fig. 15). The average differences obtained using the adjusted data were compared to the average differences that existed in the calibrated model between the calibrated steady-state heads and the initial heads. In addition, the new head-dependent fluxes were compared to the fluxes computed by the calibrated model. The results of all simulations are summarized in table 3 .

The largest changes in computed-head distributions were due to variations in recharge at the eastern boundary, maximum evapotranspiration rates, and evapotranspiration extinction depths; however, the difference between the newly computed and calibrated steady-state heads within the 309-cell area show relatively minor changes compared to the calibrated-model values. The largest changes in flux at head-dependent boundaries were due to variations in recharge at the eastern boundary, maximum evapotranspiration rates, and extinction depths, in addition to transmissivity. Variations in recharge caused substantial changes in evapotranspiration. Variations in evapotranspiration rates and extinction depths changed the flux at the basin inflow boundary and variations in transmissivity caused changes in flux at both the inflow and outflow boundaries. In conclusion, the flux at head-dependent boundaries seems to be moderately sensitive to variations in some of the data. Consequently, even though the changes in computed head that result from errors in estimation of data are relatively small, the model-calculated water-budget components might change.

\section{LIMITATIONS OF MODEL}

The limitation to the ground-water model of the Milford area is the uncertainty of water levels and values for hydraulic properties in the northern one-half of the basin and along the margins of the basin. Because of the uncertainty in the potentiometric surface and hydraulic properties, our understanding of ground-water flow in these parts of the basin is limited. Constant-head cells were used initially along the eastern recharge boundary to determine the flux entering the system from the consolidated rocks and any uncertainty in the values for head and hydraulic conductivity would lead to uncertainty in the computed flux. By maintaining all parameters within reasonable limits, the computed flux along the recharge boundary was similar to the value estimated previously.
Steep hydraulic gradients and larger cell size in the southeast and the northwest parts of the simulated area cause some differences between initial and computed heads. These values were much larger than the generally accepted calibration limits. Although the computed heads were considerably different from measured heads, the initial and computed hydraulic gradients in these areas are similar. Consequently, during transient simulations, computed head changes between stress periods were similar to actual head changes in the southeast. If future model simulations were to consider the effects of seepage from surface-water irrigation in the southeast part of the simulated area and more data were available, then model cell size in that part of the basin could be made smaller to ensure greater accuracy.

On the basis of canal-loss studies, 30 percent of all surface water and ground water used for irrigation was assumed to seep into the ground-water system. In making this simplistic assumption, variations in seepage due to the use of different methods of irrigation and differences in soil conditions were not taken into account. This assumption probably does not make a substantial difference in the overall accuracy of the calibrated model, but could make a difference in the accuracy of a computed head of a specific cell.

The effects on layer 1 due to increased withdrawals in layer 2 could not be tested accurately without additional water-level and aquifer-test data from wells completed only in deeper zones of the basin-fill aquifer. These data would be necessary to define and calibrate the verticalhead gradient and flux within the area of ground-water development.

\section{SHORT-TERM PREDICTIVE SIMULATIONS}

The model of the Milford area was used to project the effects of ground-water withdrawals from 1983 to 2020. Computed water levels at the end of the 1979-82 stress period, derived from the historical transient simulation, were used as the starting point for the short-term predictive simulations. As in the transient simulation, average values for seepage were used for all stress periods. Because the model was designed principally to simulate relative declines and possible trends in ground-water levels, no attempt was made to simulate future variations of flow in the Beaver River and its associated irrigation-canal system. Also, the extremely high flows in the Beaver River for 1983 and 1984 were not simulated.

The model was used to simulate the response of the ground-water system to three rates of ground-water withdrawal. The areal and vertical distributions of the withdrawals for 1979-82 were used for all simulations. In 

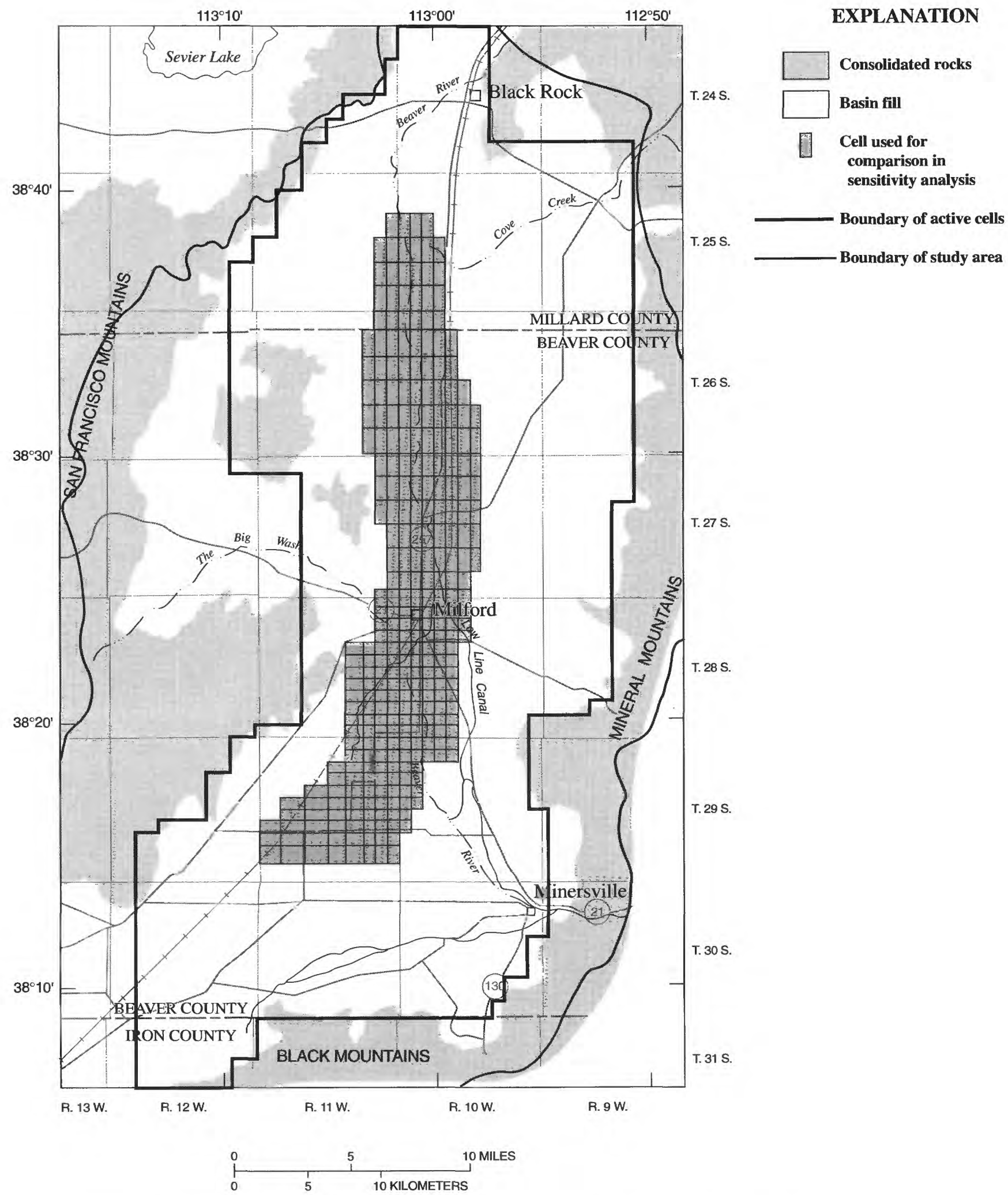

FIGURE 15.-Boundary of active cells during model simulations and areal distribution of cells used for comparison during sensitivity analysis. 
TABLE 3.-Results of sensitivity analysis for ground-water model, Milford area, Utah

[Percent change of new computed value, compared to calibrated model given in parentheses]

\begin{tabular}{|c|c|c|c|c|c|c|c|c|c|c|c|c|c|}
\hline \multirow{3}{*}{$\begin{array}{c}\begin{array}{c}\text { Hydraulic } \\
\text { property }\end{array} \\
\text { Calibrated model }\end{array}$} & \multirow{3}{*}{$\begin{array}{c}\text { Percent } \\
\text { change } \\
0\end{array}$} & \multicolumn{6}{|c|}{$\begin{array}{l}\text { Difference between initial } \\
\text { and computed head } \\
\text { difference }^{1} \text { (feet) }\end{array}$} & \multicolumn{6}{|c|}{$\begin{array}{c}\text { Flux at head-dependent } \\
\text { boundaries } \\
\text { (cubic feet per second) }\end{array}$} \\
\hline & & \multicolumn{2}{|c|}{ Layer 1} & \multicolumn{2}{|c|}{ Layer 2} & \multicolumn{2}{|c|}{ Layer 3} & \multicolumn{2}{|c|}{$\begin{array}{l}\text { Basin } \\
\text { inflow }\end{array}$} & \multicolumn{2}{|c|}{$\begin{array}{c}\text { Basin } \\
\text { outflow }\end{array}$} & \multicolumn{2}{|c|}{$\begin{array}{c}\text { Evapotrans- } \\
\text { piration }\end{array}$} \\
\hline & & 1.63 & $(0.0)$ & 1.76 & $(0.0)$ & 1.53 & $(0.0)$ & 2.67 & $(0.0)$ & 15.82 & $(0.0)$ & 37.25 & $(0.0)$ \\
\hline $\begin{array}{l}\text { Transmissivity } \\
\text { (all layers). }\end{array}$ & $\begin{array}{l}-20 \\
+20\end{array}$ & $\begin{array}{l}0.41 \\
2.61\end{array}$ & $\begin{array}{l}(74.8) \\
(60.1)\end{array}$ & $\begin{array}{l}0.08 \\
3.12\end{array}$ & $\begin{array}{l}(95.5) \\
(77.3)\end{array}$ & $\begin{array}{r}-0.18 \\
2.91\end{array}$ & $\begin{array}{r}(111.0) \\
(90.2)\end{array}$ & $\begin{array}{l}2.48 \\
2.85\end{array}$ & $\begin{array}{l}(7.1) \\
(6.7)\end{array}$ & $\begin{array}{l}13.76 \\
17.60\end{array}$ & $\begin{array}{l}(13.0) \\
(11.3)\end{array}$ & $\begin{array}{l}39.12 \\
35.66\end{array}$ & $\begin{array}{l}(5.0) \\
(4.3)\end{array}$ \\
\hline $\begin{array}{l}\text { Hydraulic conductivity } \\
\text { (layer 1). }\end{array}$ & $\begin{array}{r}-20 \\
+20\end{array}$ & $\begin{array}{l}1.11 \\
2.04\end{array}$ & $\begin{array}{l}(31.9) \\
(25.2)\end{array}$ & $\begin{array}{l}0.77 \\
2.56\end{array}$ & $\begin{array}{l}(56.3) \\
(45.5)\end{array}$ & $\begin{array}{l}0.52 \\
2.35\end{array}$ & $\begin{array}{l}(66.0) \\
(53.6)\end{array}$ & $\begin{array}{l}2.57 \\
2.77\end{array}$ & $\begin{array}{l}(3.7) \\
(3.7)\end{array}$ & $\begin{array}{l}15.33 \\
16.32\end{array}$ & $\begin{array}{l}(3.1) \\
(3.2)\end{array}$ & $\begin{array}{l}37.65 \\
36.86\end{array}$ & $\begin{array}{l}(1.1) \\
(1.0)\end{array}$ \\
\hline $\begin{array}{l}\text { Transmissivity } \\
\text { (layer 2). }\end{array}$ & $\begin{array}{r}-20 \\
+20\end{array}$ & $\begin{array}{l}1.09 \\
2.11\end{array}$ & $\begin{array}{l}(33.1) \\
(29.4)\end{array}$ & $\begin{array}{l}1.25 \\
2.24\end{array}$ & $\begin{array}{l}(29.0) \\
(27.3)\end{array}$ & $\begin{array}{l}0.99 \\
2.05\end{array}$ & $\begin{array}{l}(35.3) \\
(34.0)\end{array}$ & $\begin{array}{l}2.61 \\
2.75\end{array}$ & $\begin{array}{l}(2.2) \\
(3.0)\end{array}$ & $\begin{array}{l}14.63 \\
16.89\end{array}$ & $\begin{array}{l}(7.5) \\
(6.8)\end{array}$ & $\begin{array}{l}38.37 \\
36.26\end{array}$ & $\begin{array}{l}(3.0) \\
(2.7)\end{array}$ \\
\hline $\begin{array}{l}\text { Transmissivity } \\
\text { (layer 3). }\end{array}$ & $\begin{array}{r}-20 \\
+20\end{array}$ & $\begin{array}{l}1.50 \\
1.75\end{array}$ & $\begin{array}{l}(8.0) \\
(7.4)\end{array}$ & $\begin{array}{l}1.63 \\
1.89\end{array}$ & $\begin{array}{l}(7.4) \\
(7.4)\end{array}$ & $\begin{array}{l}1.43 \\
1.63\end{array}$ & $\begin{array}{l}(6.5) \\
(6.5)\end{array}$ & $\begin{array}{l}2.65 \\
2.69\end{array}$ & $\begin{array}{l}(0.7) \\
(0.7)\end{array}$ & $\begin{array}{l}15.54 \\
16.10\end{array}$ & $\begin{array}{l}(1.8) \\
(1.8)\end{array}$ & $\begin{array}{l}37.52 \\
36.99\end{array}$ & $\begin{array}{l}(0.7) \\
(0.7)\end{array}$ \\
\hline $\begin{array}{l}\text { Vertical conductivity } \\
\text { (all layers). }\end{array}$ & $\begin{array}{r}-20 \\
+20\end{array}$ & $\begin{array}{l}1.60 \\
1.65\end{array}$ & $\begin{array}{l}(1.8) \\
(1.2)\end{array}$ & $\begin{array}{l}1.28 \\
2.13\end{array}$ & $\begin{array}{l}(41.3) \\
(21.0)\end{array}$ & $\begin{array}{l}1.02 \\
1.92\end{array}$ & $\begin{array}{l}(33.3) \\
(25.5)\end{array}$ & $\begin{array}{l}2.67 \\
2.68\end{array}$ & $\begin{array}{l}(0.0) \\
(0.4)\end{array}$ & $\begin{array}{l}15.87 \\
15.78\end{array}$ & $\begin{array}{l}(0.3) \\
(0.3)\end{array}$ & $\begin{array}{l}37.20 \\
37.30\end{array}$ & $\begin{array}{l}(0.1) \\
(0.1)\end{array}$ \\
\hline $\begin{array}{l}\text { Vertical conductivity } \\
\text { (layers 1-2). }\end{array}$ & $\begin{array}{l}-20 \\
+20\end{array}$ & $\begin{array}{l}1.60 \\
1.65\end{array}$ & $\begin{array}{l}(1.8) \\
(1.2)\end{array}$ & $\begin{array}{l}1.27 \\
2.13\end{array}$ & $\begin{array}{l}(27.8) \\
(21.0)\end{array}$ & $\begin{array}{l}1.07 \\
1.89\end{array}$ & $\begin{array}{l}(30.1) \\
(23.5)\end{array}$ & $\begin{array}{l}2.67 \\
2.68\end{array}$ & $\begin{array}{l}(0.0) \\
(0.4)\end{array}$ & $\begin{array}{l}15.87 \\
15.78\end{array}$ & $\begin{array}{l}(0.3) \\
(0.3)\end{array}$ & $\begin{array}{l}37.20 \\
37.29\end{array}$ & $\begin{array}{l}(0.1) \\
(0.1)\end{array}$ \\
\hline $\begin{array}{l}\text { Vertical conductivity } \\
\text { (layers 2-3). }\end{array}$ & $\begin{array}{r}-20 \\
+20\end{array}$ & $\begin{array}{l}1.63 \\
1.63\end{array}$ & $\begin{array}{l}(0.0) \\
(0.0)\end{array}$ & $\begin{array}{l}1.76 \\
1.76\end{array}$ & $\begin{array}{l}(0.0) \\
(0.0)\end{array}$ & $\begin{array}{l}1.49 \\
1.56\end{array}$ & $\begin{array}{l}(2.0) \\
(2.0)\end{array}$ & $\begin{array}{l}2.67 \\
2.67\end{array}$ & $\begin{array}{l}(0.0) \\
(0.0)\end{array}$ & $\begin{array}{l}15.82 \\
15.82\end{array}$ & $\begin{array}{l}(0.0) \\
(0.0)\end{array}$ & $\begin{array}{l}37.25 \\
37.25\end{array}$ & $\begin{array}{l}(0.0) \\
(0.0)\end{array}$ \\
\hline Recharge & $\begin{array}{r}-20 \\
+20\end{array}$ & $\begin{array}{r}4.67 \\
-1.40\end{array}$ & $\begin{array}{l}(186) \\
(186)\end{array}$ & $\begin{array}{r}5.26 \\
-1.70\end{array}$ & $\begin{array}{l}(199) \\
(197)\end{array}$ & $\begin{array}{r}5.06 \\
-1.95\end{array}$ & $\begin{array}{l}(231) \\
(228)\end{array}$ & $\begin{array}{l}2.76 \\
2.64\end{array}$ & $\begin{array}{l}(3.4) \\
(1.1)\end{array}$ & $\begin{array}{l}15.04 \\
16.57\end{array}$ & $\begin{array}{l}(4.9) \\
(4.7)\end{array}$ & $\begin{array}{l}30.60 \\
43.98\end{array}$ & $\begin{array}{l}(17.9) \\
(18.1)\end{array}$ \\
\hline $\begin{array}{l}\text { Maximum } \\
\text { evapotranspiration. }\end{array}$ & $\begin{array}{r}-20 \\
+20\end{array}$ & $\begin{array}{r}-1.65 \\
3.82\end{array}$ & $\begin{array}{l}(201) \\
(134)\end{array}$ & $\begin{array}{r}-1.34 \\
3.83\end{array}$ & $\begin{array}{l}(176) \\
(118)\end{array}$ & $\begin{array}{r}-1.56 \\
3.59\end{array}$ & $\begin{array}{l}(202) \\
(135)\end{array}$ & $\begin{array}{l}2.51 \\
2.82\end{array}$ & $\begin{array}{l}(6.0) \\
(5.6)\end{array}$ & $\begin{array}{l}16.38 \\
15.48\end{array}$ & $\begin{array}{l}(3.5) \\
(2.1)\end{array}$ & $\begin{array}{l}36.54 \\
37.75\end{array}$ & $\begin{array}{l}(1.9) \\
(1.3)\end{array}$ \\
\hline $\begin{array}{l}\text { Evapotranspiration } \\
\text { extinction depth. }\end{array}$ & $\begin{array}{r}-20 \\
+20\end{array}$ & $\begin{array}{r}-1.19 \\
4.39\end{array}$ & $\begin{array}{l}(173) \\
(169)\end{array}$ & $\begin{array}{r}-1.07 \\
4.53\end{array}$ & $\begin{array}{l}(161) \\
(157)\end{array}$ & $\begin{array}{r}-1.29 \\
4.30\end{array}$ & $\begin{array}{l}(184) \\
(181)\end{array}$ & $\begin{array}{l}2.41 \\
2.96\end{array}$ & $\begin{array}{r}(9.7) \\
(10.9)\end{array}$ & $\begin{array}{l}16.37 \\
15.33\end{array}$ & $\begin{array}{l}(3.5) \\
(3.1)\end{array}$ & $\begin{array}{l}36.43 \\
38.04\end{array}$ & $\begin{array}{l}(2.2) \\
(2.1)\end{array}$ \\
\hline
\end{tabular}

\footnotetext{
${ }^{1}$ Average of the absolute difference between the initial-head distribution and the computed-head distribution in the 309-cell area where enough data were available to make a reasonable estimate of steady-state water levels or where the estimated hydraulic gradient was small (fig. 15). Negative values for difference in head indicate computed head is above initial head.
}

the first simulation, withdrawals equal to the 1979-82 average rate caused water-level declines of more than 12 $\mathrm{ft}$ near the south end of the Mineral Mountains and declines of 6 to $10 \mathrm{ft}$ in the area of pumping (fig. 16). The smaller water-level declines in the area of pumping can be attributed to decreased evapotranspiration and to decreased storage depletions (table 4), indicating that the ground-water system could conceivably be approaching a new equilibrium condition. The projected water-level declines along the eastern margin of the simulated area are a continuation of the boundary effects that were simulated at the end of the historical transient simulation.

In the second simulation, ground-water withdrawals were increased to 1.5 times the $1979-82$ average rate. This rate of ground-water withdrawal is about 15 percent larger than the maximum average rate applied in the historical, transient simulation for 1974-78 (table 1) and it is equal to the largest annual rate of withdrawal reported for 1974 (fig. 6). Although long-term ground-water withdrawals probably would not remain this large, it could approach this level for short periods as it has in recent years. This simulation resulted in projected water-level declines of more than $35 \mathrm{ft}$ at the center of a well-defined cone of depression that covered the entire southern one- half of the basin (fig. 17). As would be expected with the extent of projected water-level declines, evapotranspiration decreased and storage depletion and basin inflow at the southwest boundary increased (table 4). Minor water-level rises of less than $1 \mathrm{ft}$ were projected for the extreme north end of the basin. These rises probably are due to minor flux imbalances at the northern boundary.

The third simulation used ground-water withdrawals at double the 1979-82 rate. This simulation projected water-level declines of more than $70 \mathrm{ft}$ at the center of a well-defined cone of depression (fig. 18). Water-level declines of more than $40 \mathrm{ft}$ were projected at the eastern and western boundaries of the basin. Storage depletion becomes a large component in the water budget at this rate of withdrawal (table 4). Pumping at this rate with the current (1984) distribution of wells would be a worst-case possibility. Pumping could not approach this rate without considerable development in the north part of the basin. If substantial development did occur in the north part of the basin, the overall water-level declines would be less because withdrawals would be distributed throughout the basin rather than being restricted to the southern one-half. 

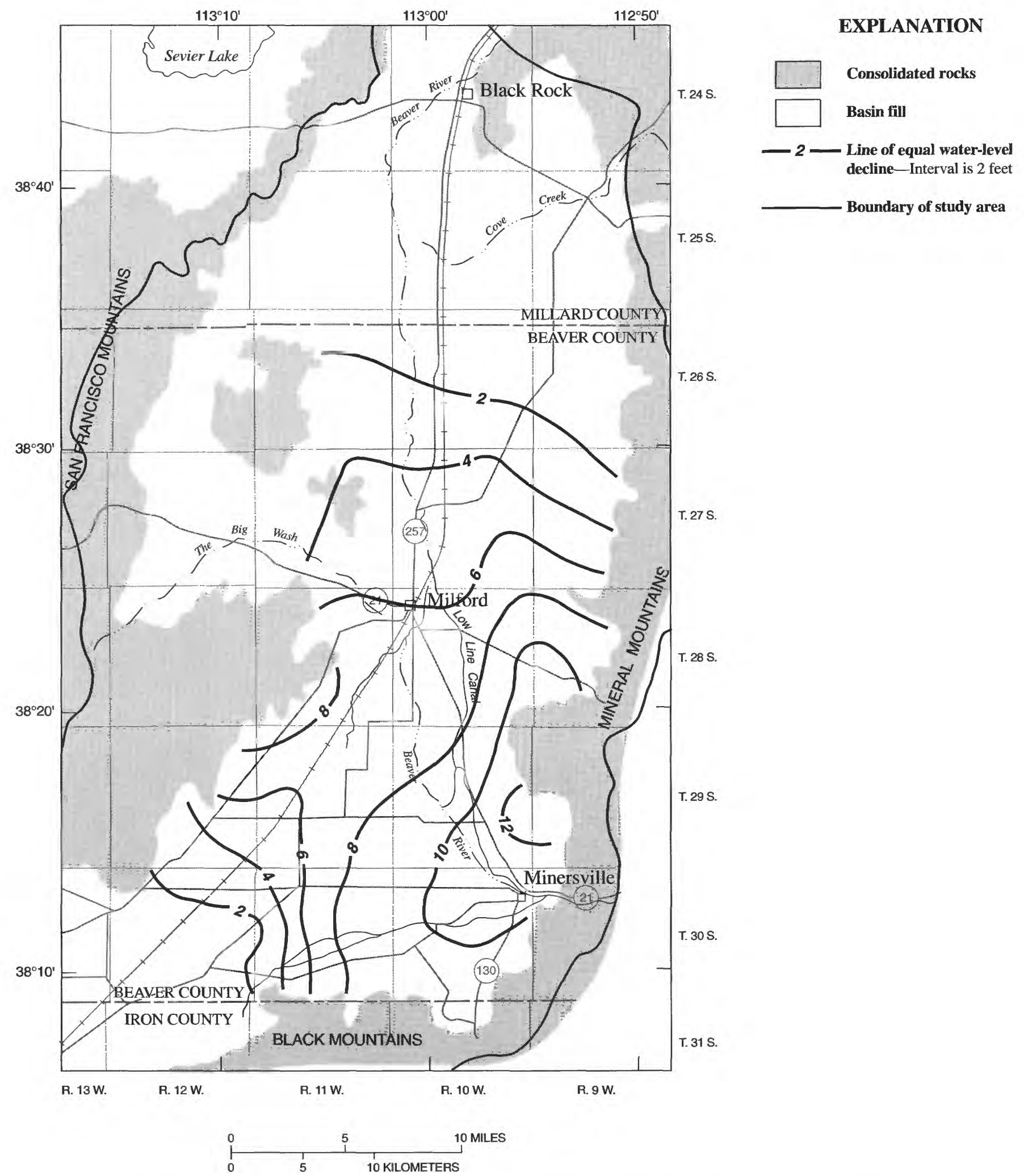

FIGURE 16.-Projected water-level declines in the basin-fill aquifer for 1983-2020, assuming ground-water withdrawals equal to the 1979-82 average rate. 


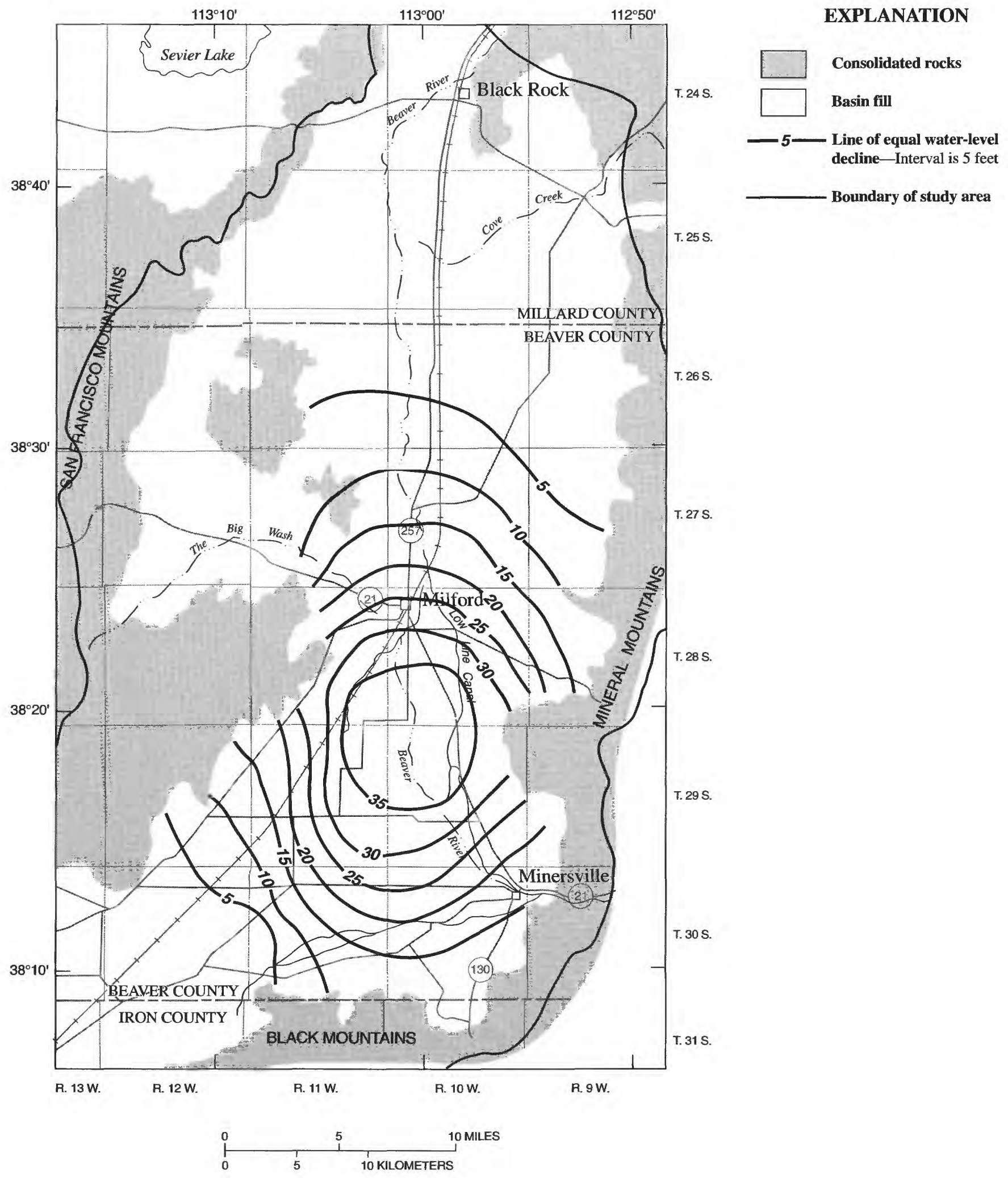

FIGURE 17.-Projected water-level declines in the basin-fill aquifer for 1983-2020, assuming ground-water withdrawals equal to 1.5 times the 1979-82 average rate. 


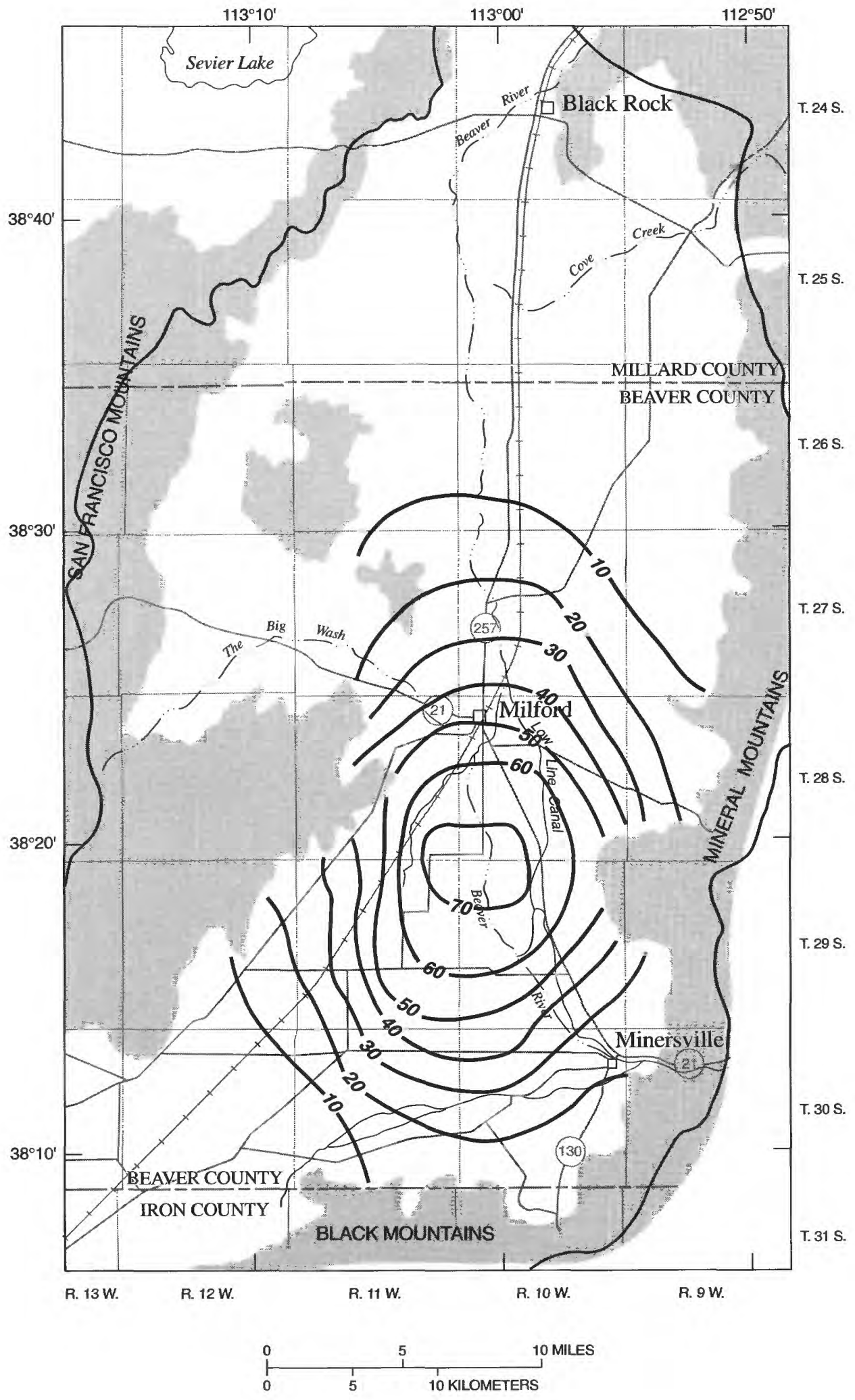

FIGURE 18.-Projected water-level declines in the basin-fill aquifer for 1983-2020, assuming ground-water withdrawals double the 1979-82 average rate. 
TABLE 4.-Projected changes in ground-water budget components due to increased ground-water withdrawals, Milford area, Utah

[Data are in cubic feet per second; acre-feet per year shown in parentheses]

\begin{tabular}{|c|c|c|c|c|}
\hline \multirow[t]{2}{*}{ Budget component } & \multirow{2}{*}{$\begin{array}{c}\text { Transient-state } \\
\text { (end of 1979-82 } \\
\text { stress period) } \\
\text { average } \\
\text { seepage }\end{array}$} & \multicolumn{3}{|c|}{$\begin{array}{l}\text { Projected water-budget rates at } \\
\text { year } 2020 \text { using } 1979-82 \text { average } \\
\text { ground-water withdrawal times }\end{array}$} \\
\hline & & 1.0 & 1.5 & 2.0 \\
\hline \multicolumn{5}{|l|}{ Recharge: } \\
\hline $\begin{array}{l}\text { Subsurface inflow from consolidated } \\
\text { rocks in the Mineral Mountains. } \\
\text { Subsurface inflow from adioining areas: }\end{array}$ & $\begin{array}{c}32.9 \\
(23,800)\end{array}$ & $\begin{array}{c}32.9 \\
(23,800)\end{array}$ & $\begin{array}{c}32.9 \\
(23,800)\end{array}$ & $\begin{array}{c}32.9 \\
(23,800)\end{array}$ \\
\hline 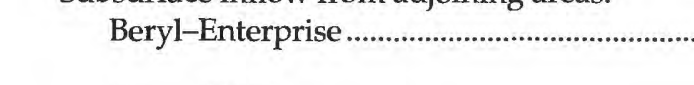 & $\begin{array}{l}3.44 \\
(2,490)\end{array}$ & $\begin{array}{c}4.41 \\
(3,190)\end{array}$ & $\begin{array}{c}5.85 \\
(4,240)\end{array}$ & $\begin{array}{c}7.34 \\
(5,310)\end{array}$ \\
\hline 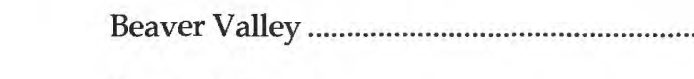 & $\begin{array}{c}5.02 \\
(3,630)\end{array}$ & $\begin{array}{c}5.02 \\
(3,630)\end{array}$ & $\begin{array}{c}5.02 \\
(3,630)\end{array}$ & $\begin{array}{c}5.02 \\
(3,630)\end{array}$ \\
\hline Cove Fort area. & $(1,720)$ & $\begin{array}{c}2.37 \\
(1,720)\end{array}$ & $\begin{array}{c}2.37 \\
(1,720)\end{array}$ & $\begin{array}{c}2.37 \\
(1,720)\end{array}$ \\
\hline \multicolumn{5}{|l|}{$\begin{array}{l}\text { Seepage from streams, canals, and } \\
\text { unconsumed irrigation water. }\end{array}$} \\
\hline Seepage from the Beaver River ...................... & $(1,500)$ & $\begin{array}{c}2.07 \\
(1,500)\end{array}$ & $\begin{array}{c}2.07 \\
(1,500)\end{array}$ & $\begin{array}{c}2.07 \\
(1,500)\end{array}$ \\
\hline 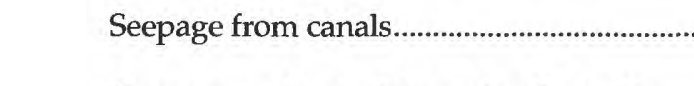 & $(1,930)$ & $\begin{array}{c}2.66 \\
(1,930)\end{array}$ & $\begin{array}{c}2.66 \\
(1,930)\end{array}$ & $\begin{array}{c}2.66 \\
(1,930)\end{array}$ \\
\hline $\begin{array}{l}\text { Unconsumed irrigation water derived } \\
\text { from ground-water sources. }\end{array}$ & $\begin{array}{c}19.1 \\
(13,800)\end{array}$ & $\begin{array}{c}19.1 \\
(13,800)\end{array}$ & $\begin{array}{c}28.6 \\
(20,700)\end{array}$ & $\begin{array}{c}38.1 \\
(27,600)\end{array}$ \\
\hline $\begin{array}{l}\text { Unconsumed irrigation water derived } \\
\text { from surface-water sources. }\end{array}$ & $\begin{array}{c}8.78 \\
(6,360)\end{array}$ & $\begin{array}{c}8.78 \\
(6,360)\end{array}$ & $\begin{array}{c}8.78 \\
(6,360)\end{array}$ & $\begin{array}{c}8.78 \\
(6,360)\end{array}$ \\
\hline 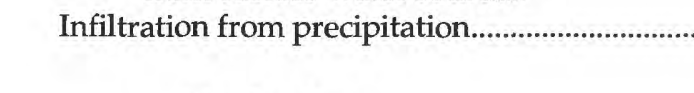 & $\begin{array}{l}\ldots .4 .77 \\
(3,450)\end{array}$ & $\begin{array}{c}4.77 \\
(3,450)\end{array}$ & $\begin{array}{r}4.77 \\
(3,450)\end{array}$ & $\begin{array}{c}4.77 \\
(3,450)\end{array}$ \\
\hline 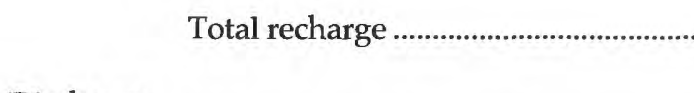 & $\begin{array}{l}0.81 .1 \\
(58,700)\end{array}$ & $\begin{array}{c}82.1 \\
(59,400)\end{array}$ & $\begin{array}{c}93.0 \\
(67,300)\end{array}$ & $\begin{array}{c}104 \\
(75,300)\end{array}$ \\
\hline $\begin{array}{l}\text { Discharge: } \\
\text { Subsurface outflow to adjoining areas } \\
\text { on northwestern boundary. }\end{array}$ & $\begin{array}{c}15.2 \\
(11,000)\end{array}$ & $\begin{array}{c}15.1 \\
(10,900)\end{array}$ & $\begin{array}{c}15.1 \\
(10,900)\end{array}$ & $\begin{array}{c}15.1 \\
(10,900)\end{array}$ \\
\hline 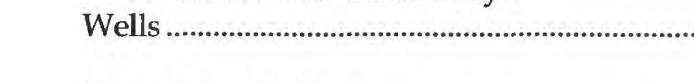 & $(46,000)$ & $\begin{array}{c}63.6 \\
(46,000)\end{array}$ & $\begin{array}{c}95.4 \\
(69,100)\end{array}$ & $\begin{array}{c}127 \\
(92,000)\end{array}$ \\
\hline 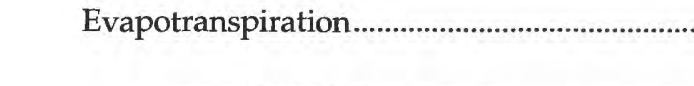 & $\begin{array}{l}(12,300) \\
(17.0\end{array}$ & $\begin{array}{c}13.3 \\
(9,630)\end{array}$ & $\begin{array}{c}10.4 \\
(7,530)\end{array}$ & $\begin{array}{c}8.88 \\
(5,950)\end{array}$ \\
\hline Total discharge & $\begin{array}{l}\ldots . . .95 .8 \\
\ldots \ldots . . .(69,400)\end{array}$ & $\begin{array}{c}92.0 \\
(66,600)\end{array}$ & $\begin{array}{c}121 \\
(87,600)\end{array}$ & $\begin{array}{c}151 \\
(109,000)\end{array}$ \\
\hline \multicolumn{5}{|l|}{ Change in storage: } \\
\hline Water entered into storage ............................ & (325) & 0.0 & 0.0 & 0.0 \\
\hline Water removed from storage & $(10,900)$ & $\begin{array}{c}9.93 \\
(7,200)\end{array}$ & $\begin{array}{c}27.8 \\
(20,100)\end{array}$ & $\begin{array}{c}47.0 \\
(34,000)\end{array}$ \\
\hline $\begin{array}{l}\text { Net change in storage equals difference } \\
\text { between water entered into storage and } \\
\text { water removed from storage. }\end{array}$ & $\begin{array}{c}14.6 \\
(10,600)\end{array}$ & $\begin{array}{c}9.93 \\
(7,200)\end{array}$ & $\begin{array}{c}27.8 \\
(20,100)\end{array}$ & $\begin{array}{c}47.0 \\
(34,000)\end{array}$ \\
\hline
\end{tabular}




\section{SIMULATION OF HYPOTHETICAL DEVELOPMENT ALTERNATIVES}

\section{CRITERIA}

The calibrated flow model for the Milford area was used to project the long-term effects of ground-water withdrawals under different applied stresses. Alternatives were designed to test the effects of withdrawals at a rate equal to the "sustained" yield of the ground-water system and to simulate development necessary for the capture of natural discharge. In most cases, the pumping distributions do not have practical applications. The concept of "sustained" yield is used by the States of Nevada and Utah, by which water rights generally are allocated on the basis of the estimated, average annual recharge to the basin in order to prevent long-term "mining" of ground water. Model-simulated responses of water-level declines and recovery and changes in discharge and storage were used to compare the effect of different applied stresses on the ground-water system.

Each development alternative was simulated for an arbitrary period of 600 years. The first 300 years simulated pumping, followed by 300 years of recovery. The long simulation period allowed the system to respond to the new stress and to approach a new equilibrium.

Each hypothetical development alternative was constrained by the following arbitrary requirements: Pumping wells were not located (1) where the depth to water exceeds $200 \mathrm{ft}$, (2) where land-surface slopes are larger than $200 \mathrm{ft} / \mathrm{mi}$, (3) where the saturated thickness in any model cell is less than $200 \mathrm{ft}$, and (4) where cells are bounded on two sides by consolidated rocks. Within the simulated area, no cells had transmissivity values that were considered to be too small for pumping (less than $1.2 \times 10^{-2} \mathrm{ft}^{2} / \mathrm{s}$ ). Pumping requirements included (1) one well per 160 acres, (2) a maximum average rate of 0.552 $\mathrm{ft}^{3} / \mathrm{s}$ (400 acre-ft/yr) for each well, and (3) withdrawals equally divided between the upper two model layers. All simulations assumed net ground-water withdrawal, so it was not necessary to simulate the recirculation of pumped water to the aquifer.

Hypothetical development alternatives simulated for the basin were as follows:

A. Concentrated pumping centers, withdrawing ground water at a rate equal to the estimated average annual recharge-Alternative $\mathrm{A} 1$ concentrated pumping in the southern one-half of the simulated area; alternative A2 concentrated pumping in the northern one-half of the simulated area; and alternative $\mathrm{A} 3$ concentrated pumping in two equal centers, one in the south and one in the north.
B. Strategically placed distribution of withdrawals that efficiently captured natural discharge, which includes evapotranspiration and basin outflow-Alternative $B 1$ maintained pumping at a rate equal to the estimated average annual recharge; alternative B2 maintained pumping at 1.25 times the estimated average annual recharge; and alternative B3 maintained pumping at 1.75 times the estimated average annual recharge for the first 50 years and then at a rate equal to the estimated annual recharge for the remaining 250 years.

Specific economic considerations were not addressed, but were indirectly considered when placing constraints on the model simulations. Possible degradation of water quality due to recirculation of pumped water was not considered in the simulations.

For each development alternative, a set of four plots was made to graphically portray the response of the ground-water system to the applied stress. The first plot shows the average water-level decline within all pumped cells at the end of each stress period. The second plot shows the change in basin inflow and outflow through the two general-head boundaries. In the other two plots, the net change in storage and natural discharge at the end of each stress period are divided by total recharge. Total recharge was calculated at the end of each stress period by adding any increase in basin inflow entering through the southwest general-head boundary to the other sources of recharge that remain constant throughout the simulation. Natural discharge includes evapotranspiration and basin outflow. If the ground-water gradient was reversed due to declining water levels in the northern onehalf of the basin, the computed basin inflow from the northwest general-head boundary was subtracted from the basin outflow to get the net basin outflow that was then used to determine natural discharge. The simulated inflow at the north end of the basin was not added to the total recharge because it was accounted for by reducing outflow. During the recovery phase of each simulation, steady-state ground-water withdrawal, which was defined as part of the steady-state conditions, was included with natural discharge; otherwise, the potentiometric surface at the end of each simulation would be higher than the original steady-state potentiometric surface.

Plots of storage versus recharge and natural discharge versus recharge can be used to evaluate the effectiveness of each development alternative to approach a new equilibrium condition, to capture natural discharge, and to let ground-water levels recover. Ideally, if a new equilibrium condition is achieved during the 300 years of pumping, then the ratio of water removed from storage to recharge and the ratios of natural discharge to recharge would stabilize. If all natural discharge was captured during pumping, then the ratios would equal zero. If full 
recovery was achieved at the end of the 600-year simulation, then the ratio of water entered into storage to recharge would equal zero and the ratio of natural discharge to recharge would equal one.

All hypothetical simulations used calibrated, steadystate conditions for the initial conditions. The simulations were designed to test the effects of hypothetical groundwater development patterns and did not incorporate the present pattern.

\section{DEVELOPMENT ALTERNATIVE A1}

In this simulation, net ground-water withdrawals were held equal to the estimated annual recharge. Ground water was withdrawn from a concentrated pumping center covering 105 cells that was located in the southern one-half of the simulated area (fig. 19). Withdrawals were divided evenly between the upper two model layers. The withdrawal for each cell depended on its size and ranged from $0.552 \mathrm{ft}^{3} / \mathrm{s}(400 \mathrm{acre}-\mathrm{ft} / \mathrm{yr})$ to $0.828 \mathrm{ft}^{3} / \mathrm{s}$ (599 acre-ft/yr).

After 300 years of pumping, a distinct cone of depression had developed covering the entire southern one-half of the simulated area and extending into the northern one-half (fig. 19). Computed water-level declines at the basin boundaries were locally more than $100 \mathrm{ft}$. The average water-level decline within the pumped area was about $160 \mathrm{ft}$ (fig. 20). Boundary effects at both generalhead boundaries began to occur after 25 years of pumping (fig. 21). Basin inflow from the Beryl-Enterprise area increased from $2.65 \mathrm{ft}^{3} / \mathrm{s}(1,920 \mathrm{acre}-\mathrm{ft} / \mathrm{yr})$ as pumping began, to about $4.65 \mathrm{ft}^{3} / \mathrm{s}(3,370$ acre-ft/ $\mathrm{yr})$ by 300 years. Although the computed basin outflow did not decrease substantially, the net basin outflow at the northwest general-head boundary decreased $7.60 \mathrm{ft}^{3} / \mathrm{s}(5,500$ acre-ft / yr $)$ because of the reversal of the hydraulic gradient at the southern end of this boundary.

After pumping ended at 300 years, water levels initially recovered rapidly with most of the water recharging the basin going into storage (figs. 20, 22). After the full 300 years of recovery, water levels had returned to within $3 \mathrm{ft}$ of the original level throughout most of the basin. Only in the extreme southeast part were residual waterlevel declines more than $5 \mathrm{ft}$; in this area, only a small quantity of water was entering the basin fill from the consolidated rocks (fig. 23).

This development alternative is not the most efficient for capturing natural discharge-only 80 percent was eliminated (fig. 24). With water-level declines of less than $25 \mathrm{ft}$ for most of the northern one-half of the basin, evapotranspiration was not completely eliminated. Although net basin outflow through the general-head boundary was reduced, the computed basin outflow was reduced only slightly. A new equilibrium condition was not reached as shown in figures $20,21,22$, and 24 ; therefore, water was removed from storage throughout the 300 years of pumping. As a result, almost 25 years of recovery were required to replenish the ground-water system before natural discharge began to increase.

\section{DEVELOPMENT ALTERNATIVE A2}

The net ground-water withdrawals for development alternative $\mathrm{A} 2$, like development alternative $\mathrm{A} 1$, were held equal to the estimated annual recharge. Ground water was withdrawn from a concentrated pumping center in the northern one-half of the simulated area. As shown in figure 25, 55 cells were pumped at a rate of $1.104 \mathrm{ft}^{3} / \mathrm{s}$ (799 acre-ft/yr) per cell, evenly divided between the upper two layers.

As with development alternative A1, 300 years of pumping produced a cone of depression that enveloped the entire northern one-half of the basin (fig. 25). Because of smaller transmissivity values in this part of the basin, the water-level declines were much larger, averaging nearly $220 \mathrm{ft}$ in the pumped area (figs. 25, 26). After 25 years, large boundary effects began to occur along the northwest general-head boundary (fig. 27). After 300 years of pumping, the hydraulic gradient had been reversed along part of this boundary so that basin inflow was approaching basin outflow, thus making net basin outflow small.

In the initial stages of recovery, water levels began to rise rapidly with most of the water going into storage (figs. 26, 28). In this development alternative, more water than usual went into storage due to the increased basin inflow along the northern general-head boundary. At the end of the full recovery period, water levels had returned to within $5 \mathrm{ft}$ of the starting level throughout most of the pumped area (fig. 29); however, residual water-level declines were larger than $30 \mathrm{ft}$ in the northeast corner where the Cove Creek drainage enters the basin. The eastern model boundary in this area has a fixed flow rate while the northern boundary has no flow entering the groundwater system. The boundary conditions as defined might be unrealistic; but the lack of data prevents the use of any other type of boundary. The residual water-level declines for this simulation probably represent a worst-case situation.

Like development alternative A1, this development alternative is not efficient at capturing natural discharge, eliminating only 80 percent (fig. 30). Although basin outflow through the general-head boundary was reduced and evapotranspiration eliminated in the northern one- 


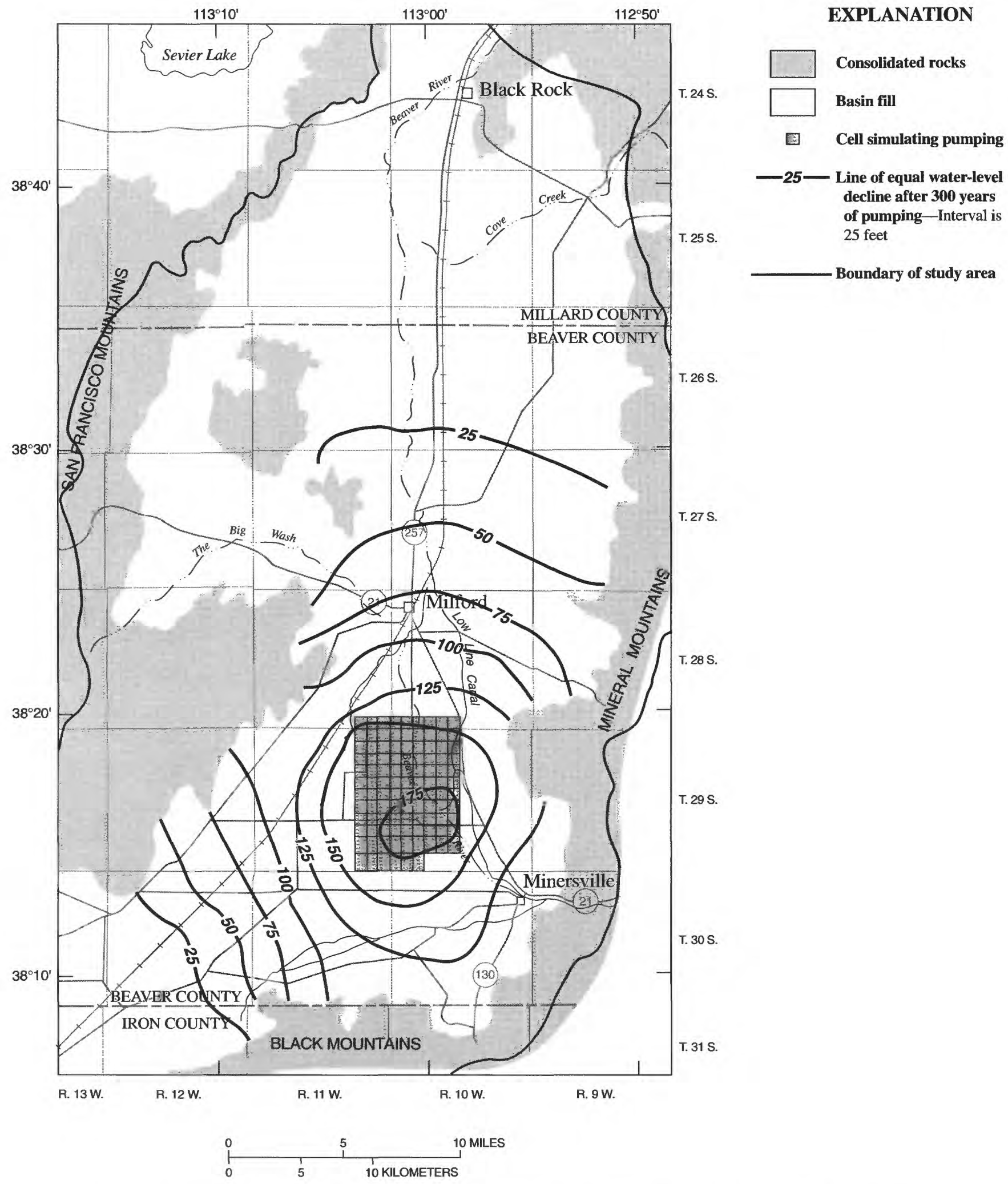

FIGURE 19.-Simulated water-level declines after 300 years of pumping and areal distribution of cells simulating pumping for development alternative $\mathrm{A} 1$. 


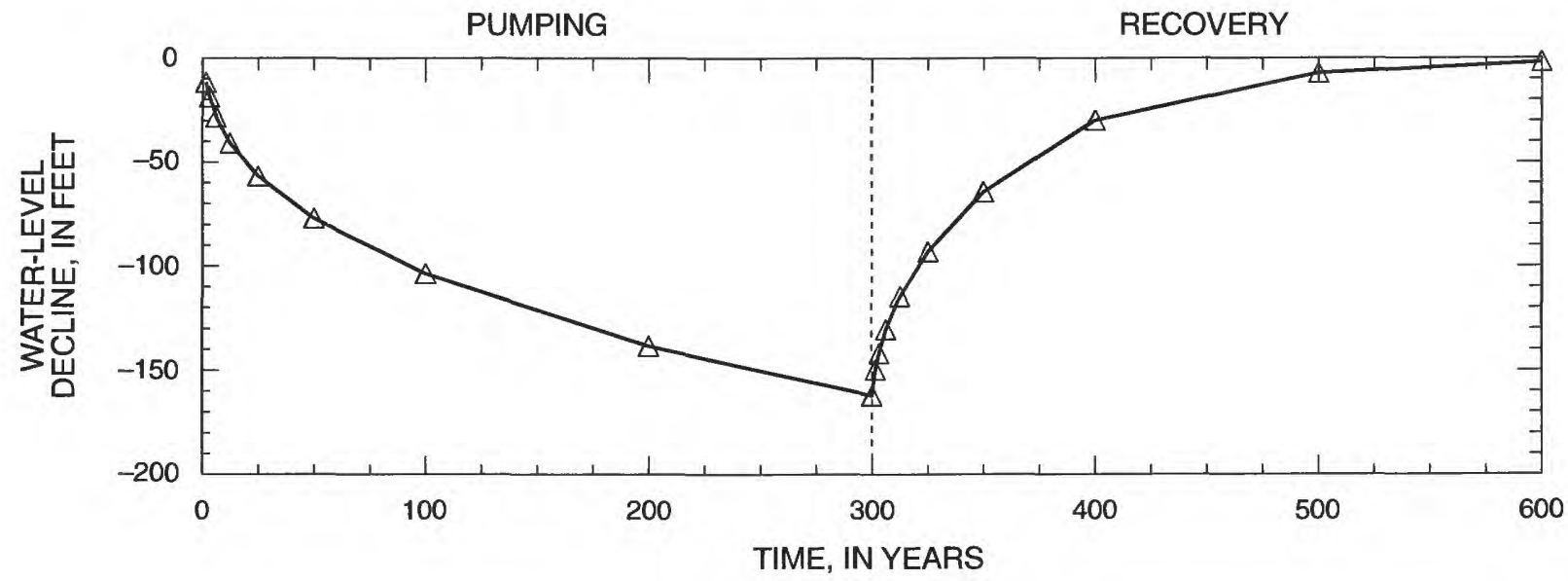

FIGURE 20,- Simulated average water-level decline and recovery in model cells containing pumped wells for development alternative $\mathrm{A} 1$.

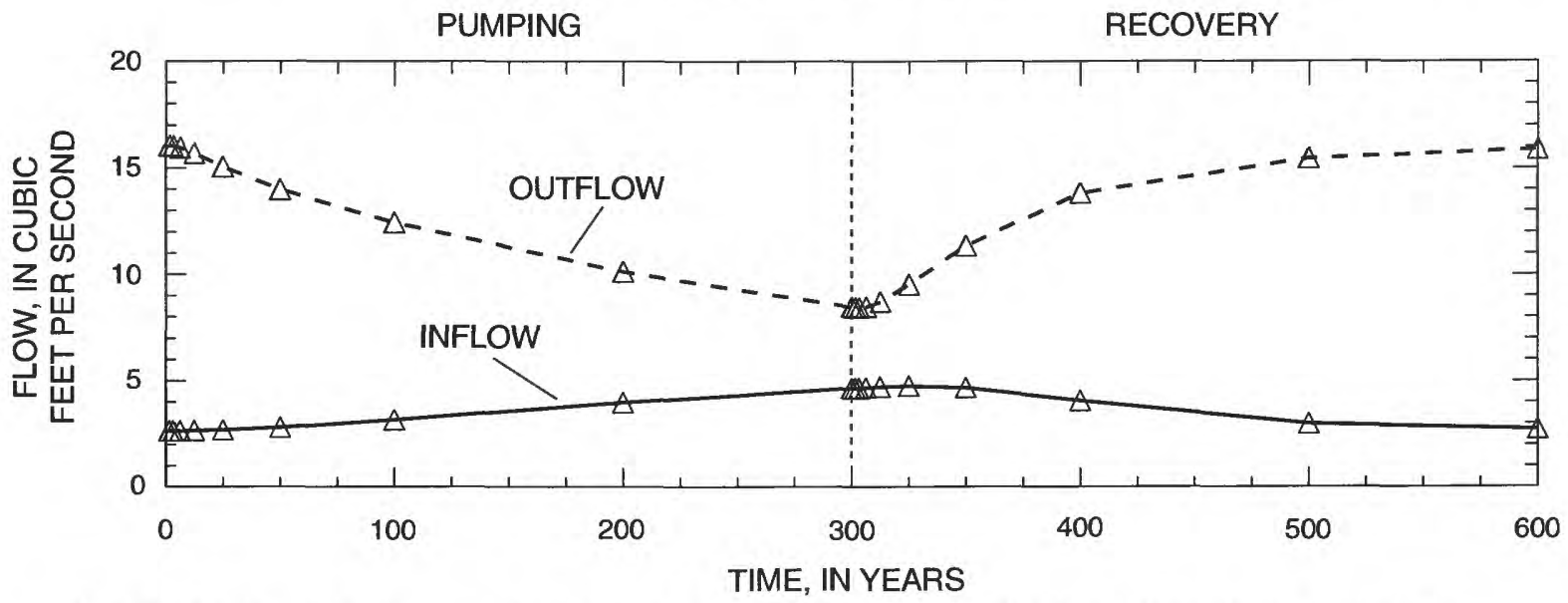

FIGURE 21.-Simulated changes in basin inflow and net outflow at general-head boundaries during pumping and recovery for development alternate $\mathrm{A} 1$.

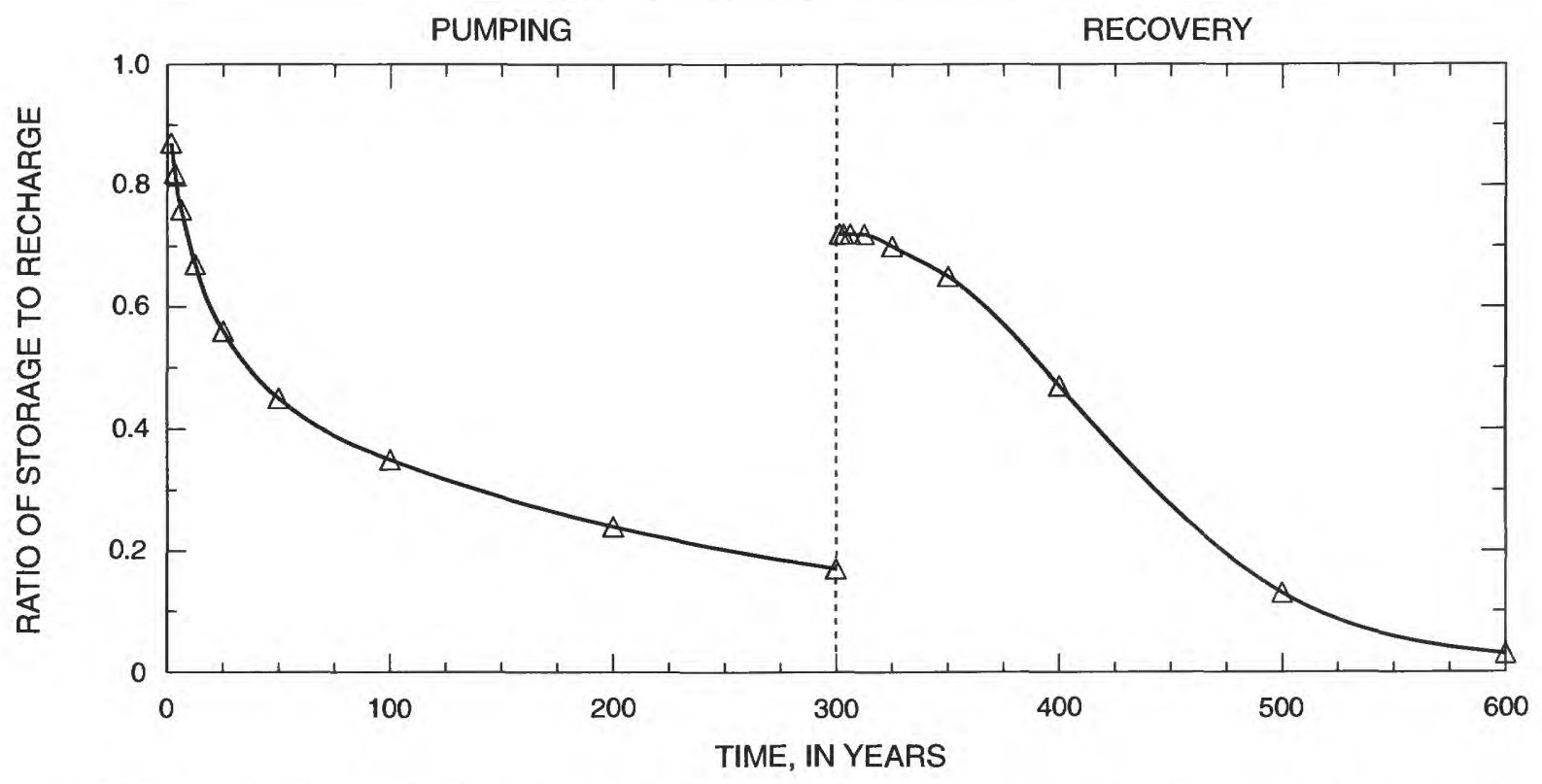

FIGURE 22.-Simulated changes in the ratios of water removed from storage during pumping to recharge and water added to storage during recovery to recharge for development alternative A1. 


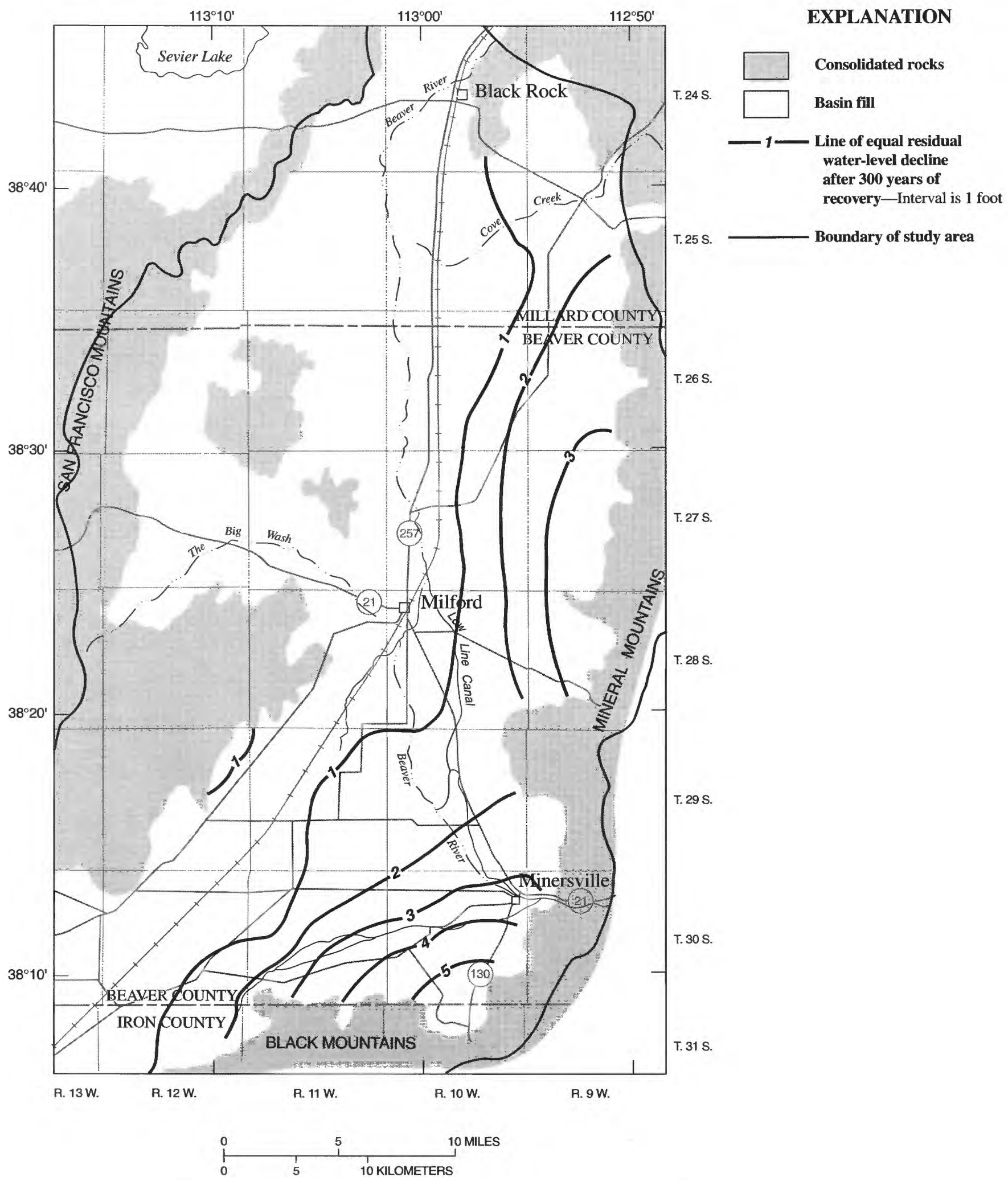

FIGURE 23.-Simulated residual water-level declines after 300 years of recovery for development alternate A1. 


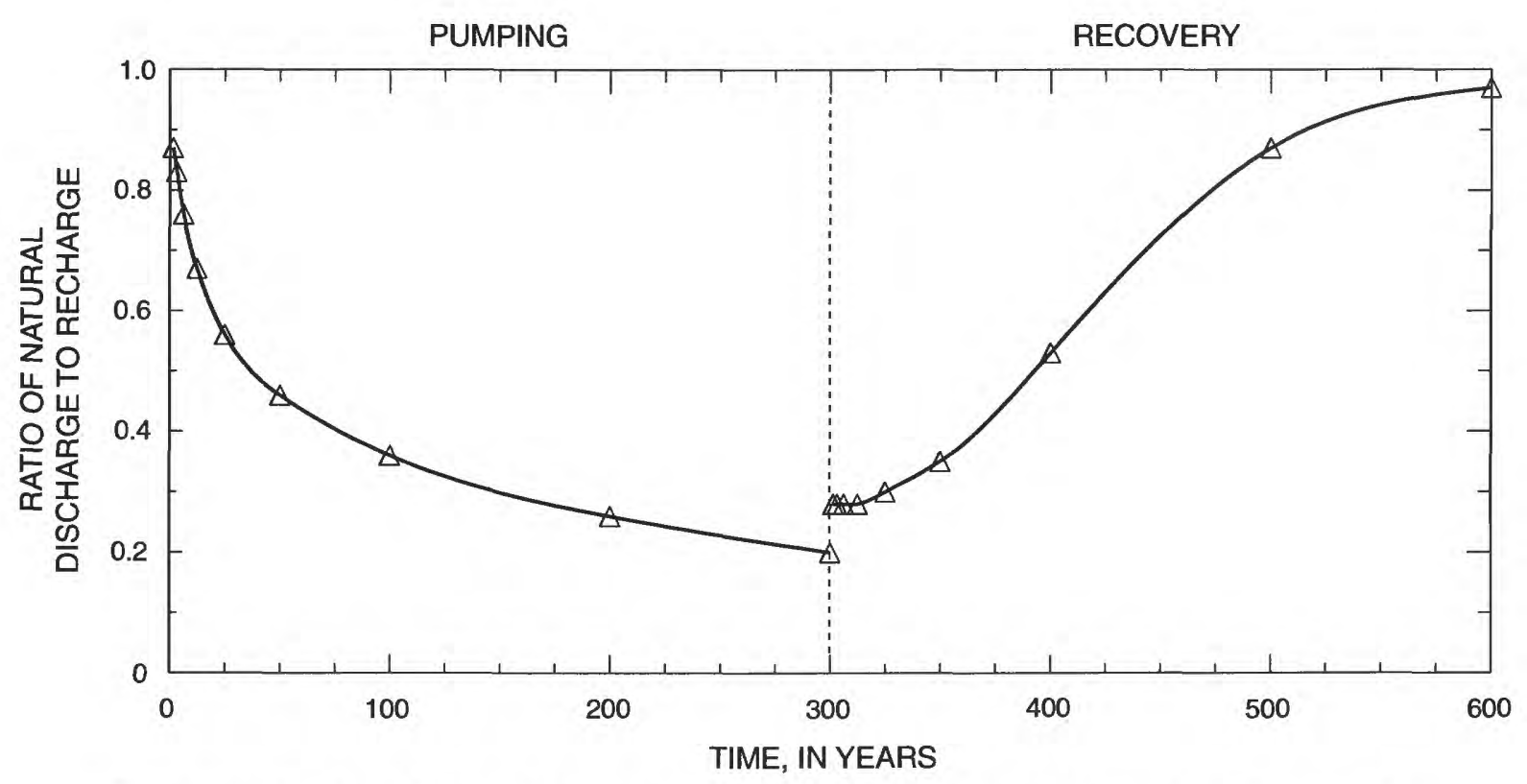

FIGURE 24.-Simulated change in the ratio of natural discharge to recharge during pumping and recovery for development alternative A1.

half of the basin, evapotranspiration remained substantial in the southern one-half. A new equilibrium was not reached, with changes in storage and natural discharge still occurring (figs. 26, 27, 28, 30). Because large quantities of water were removed from storage, over 25 years of recovery were required before substantial increases in natural discharge began to appear.

\section{DEVELOPMENT ALTERNATTVE A3}

In this simulation, there were two centers of concentrated pumping, one in the north and one in south as shown in figure 31 . Ground-water withdrawals were split evenly between the two areas and held equal to the estimated annual recharge. A total of 84 cells have simulated withdrawals with $0.552 \mathrm{ft}^{3} / \mathrm{s}(400$ acre- $\mathrm{ft} / \mathrm{yr})$ withdrawn from each cell in the south and $1.104 \mathrm{ft}^{3} / \mathrm{s}(799$ acre-ft/yr) withdrawn from each cell in the north. The large withdrawals in each cell were evenly divided between the upper two layers.

When ground-water withdrawals were concentrated in two areas, two cones of depression developed during the pumping period (fig. 31). The cone of depression in the north is well defined; whereas the cone of depression in the south is shallower and less well defined. This is the result of much smaller transmissivity values in the north. The maximum water-level decline in the north was more than $160 \mathrm{ft}$; in the south it was about $60 \mathrm{ft}$. The average water-level decline at the end of pumping for both areas was almost $76 \mathrm{ft}$ (fig. 32). Unlike the two previous development alternatives, substantial water-level declines were present along the entire eastern boundary (fig. 31). By dividing the withdrawals into two centers, effects at the general-head boundaries were moderated. Basin inflow increased slightly, whereas net basin outflow decreased substantially, but not as much as in development alternative A2 (fig. 33).

Because of the smaller water-level declines, which were distributed over a larger area, water levels recovered more rapidly than in the previous development alternatives. More water initially went into storage (figs. 32 and 34). Like development alternative A2, residual water-level declines after the full recovery period were large-more than $12 \mathrm{ft}$-in the extreme northeast corner (fig. 35). The entire southern one-half and the central part of the northern one-half of the basin recovered to within $2 \mathrm{ft}$ of the original potentiometric surface. As shown in figure 33, water levels had recovered sufficiently so that the general-head boundaries had essentially returned to near steady-state conditions after 100 years.

This development alternative shows the benefits of distributing rather than concentrating ground-water withdrawals. This development alternative was 86 percent effective in eliminating natural discharge, substantially better than development alternatives $\mathrm{A} 1$ and $\mathrm{A} 2$. As shown in figures 34 and 36 , the rate of change in water removed from storage and natural discharge became small after 100 years as a new equilibrium was approached. 


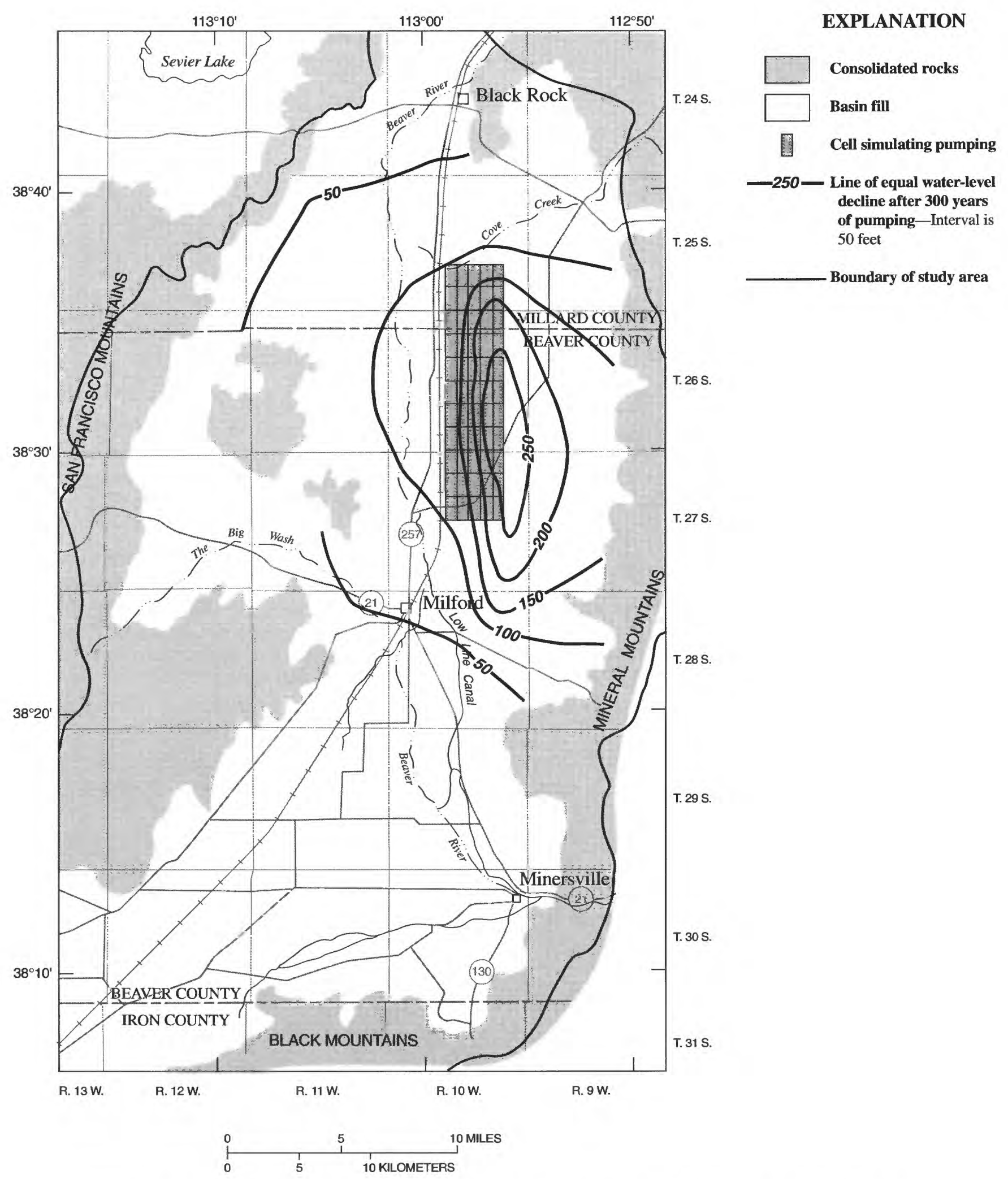

FIGURE 25.-Simulated water-level declines after 300 years of pumping and areal distribution of cells simulating pumping for development alternative A2. 


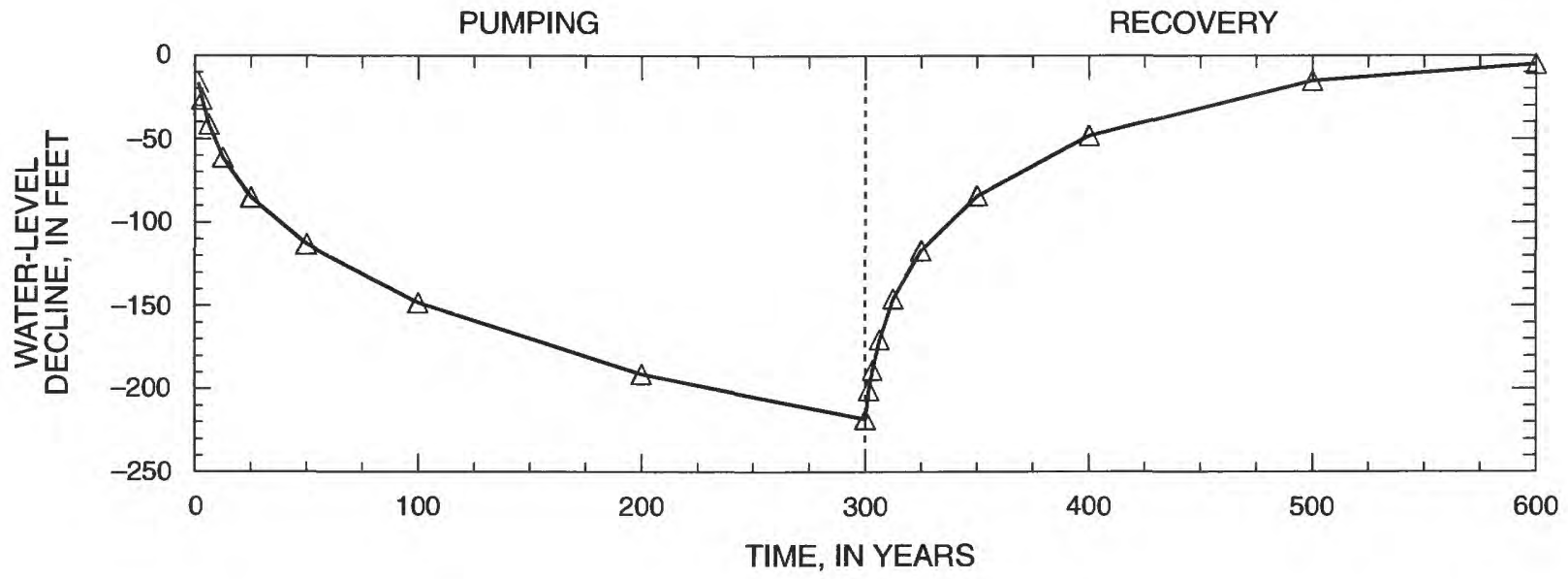

FigURE 26.- Simulated average water-level decline and recovery in model cells containing pumped wells for development alternative $\mathrm{A} 2$.

PUMPING RECOVERY

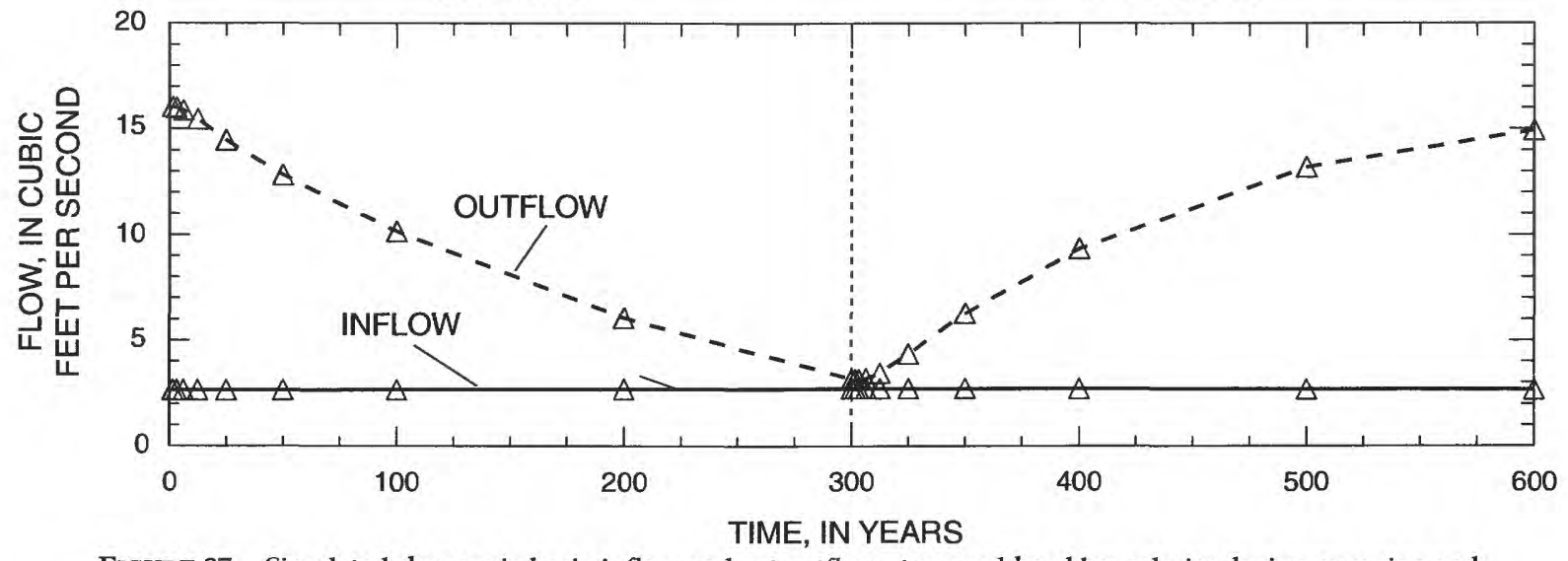

FIGURE 27.-Simulated changes in basin inflow and net outflow at general-head boundaries during pumping and recovery for development alternative $\mathrm{A} 2$.

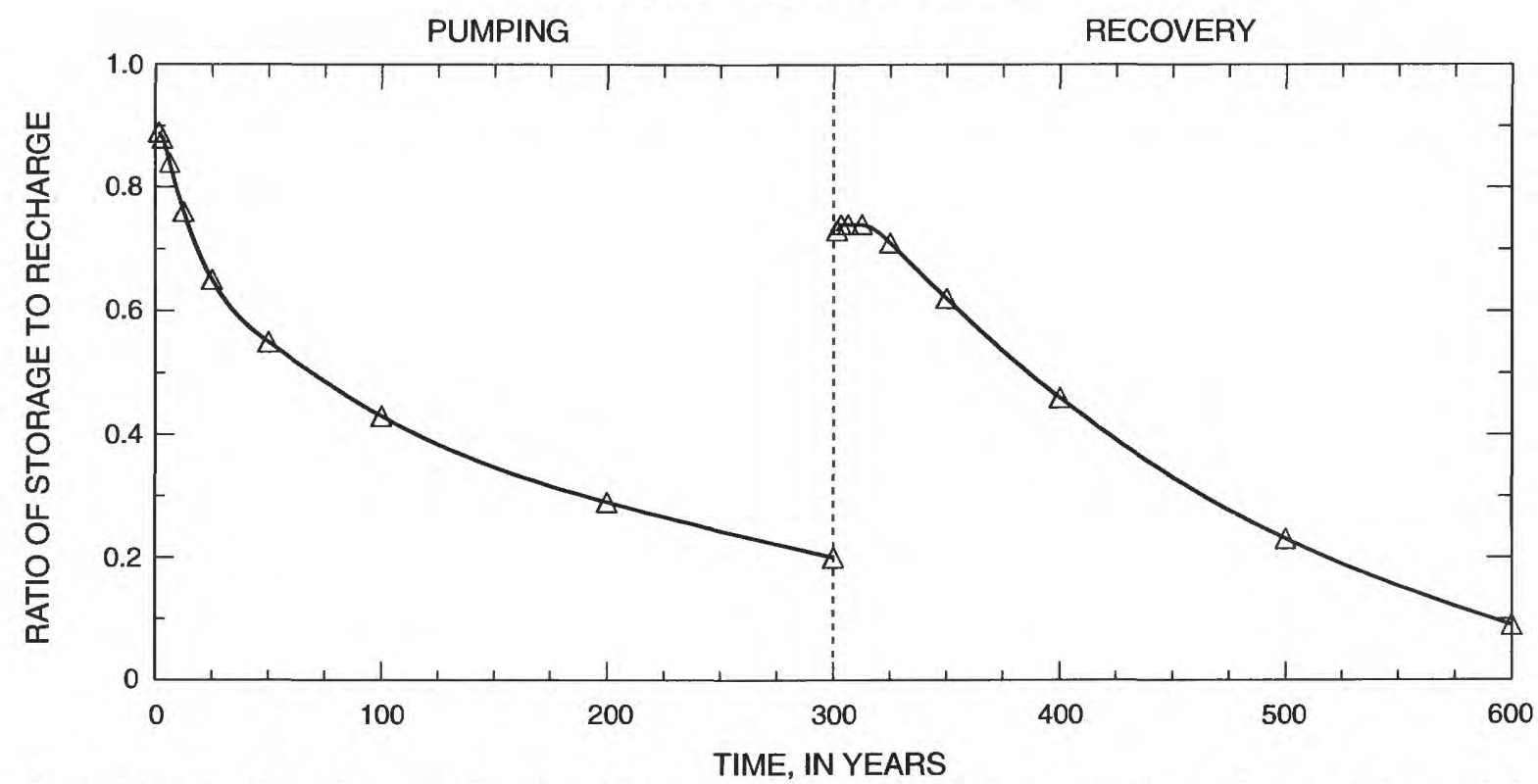

FIGURE 28.-Simulated changes in the ratios of water removed from storage during pumping to recharge and water added to storage during recovery to recharge for development alternative A2. 


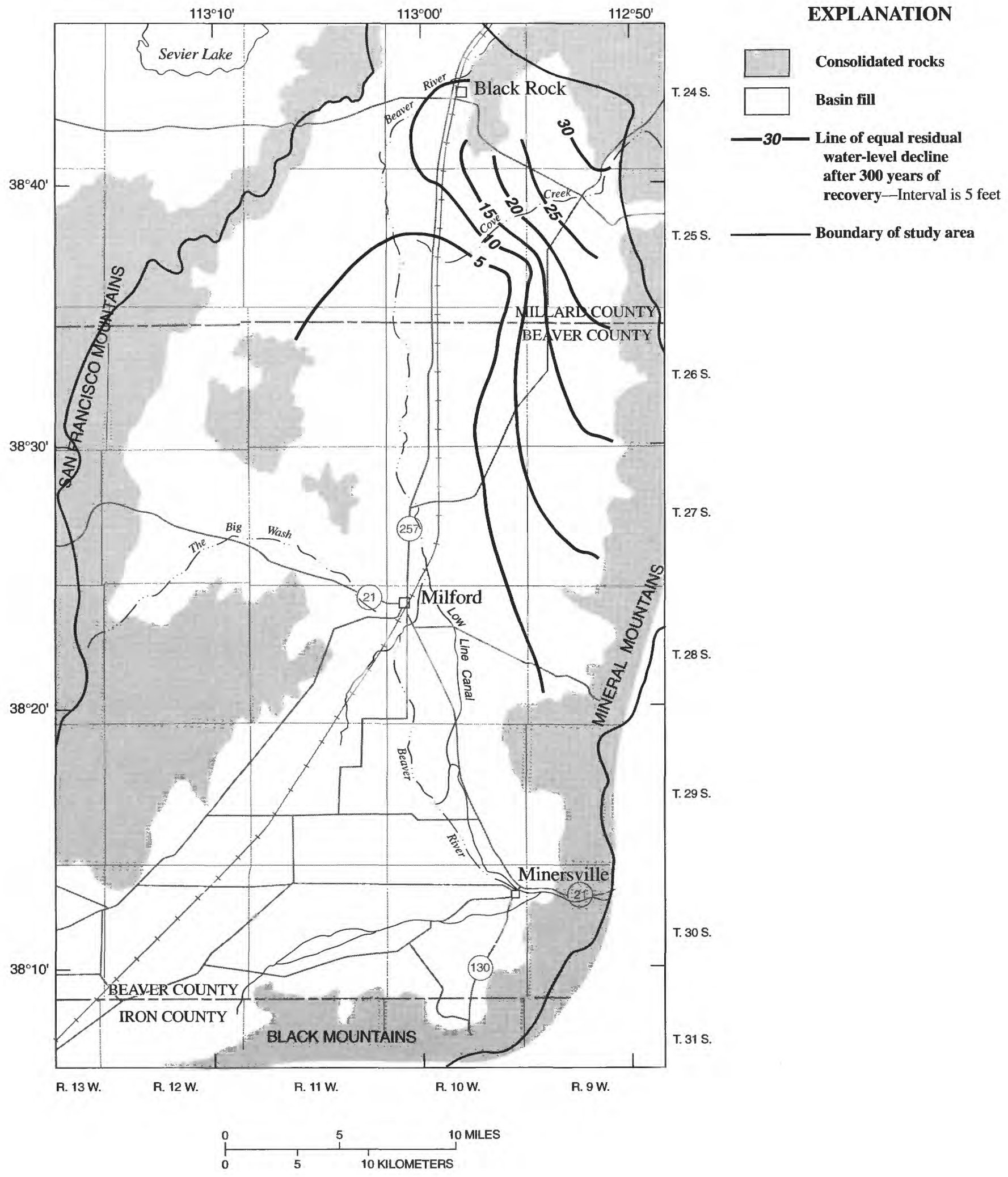

FIGURE 29.- Simulated residual water-level declines after 300 years of recovery for development alternative A2. 


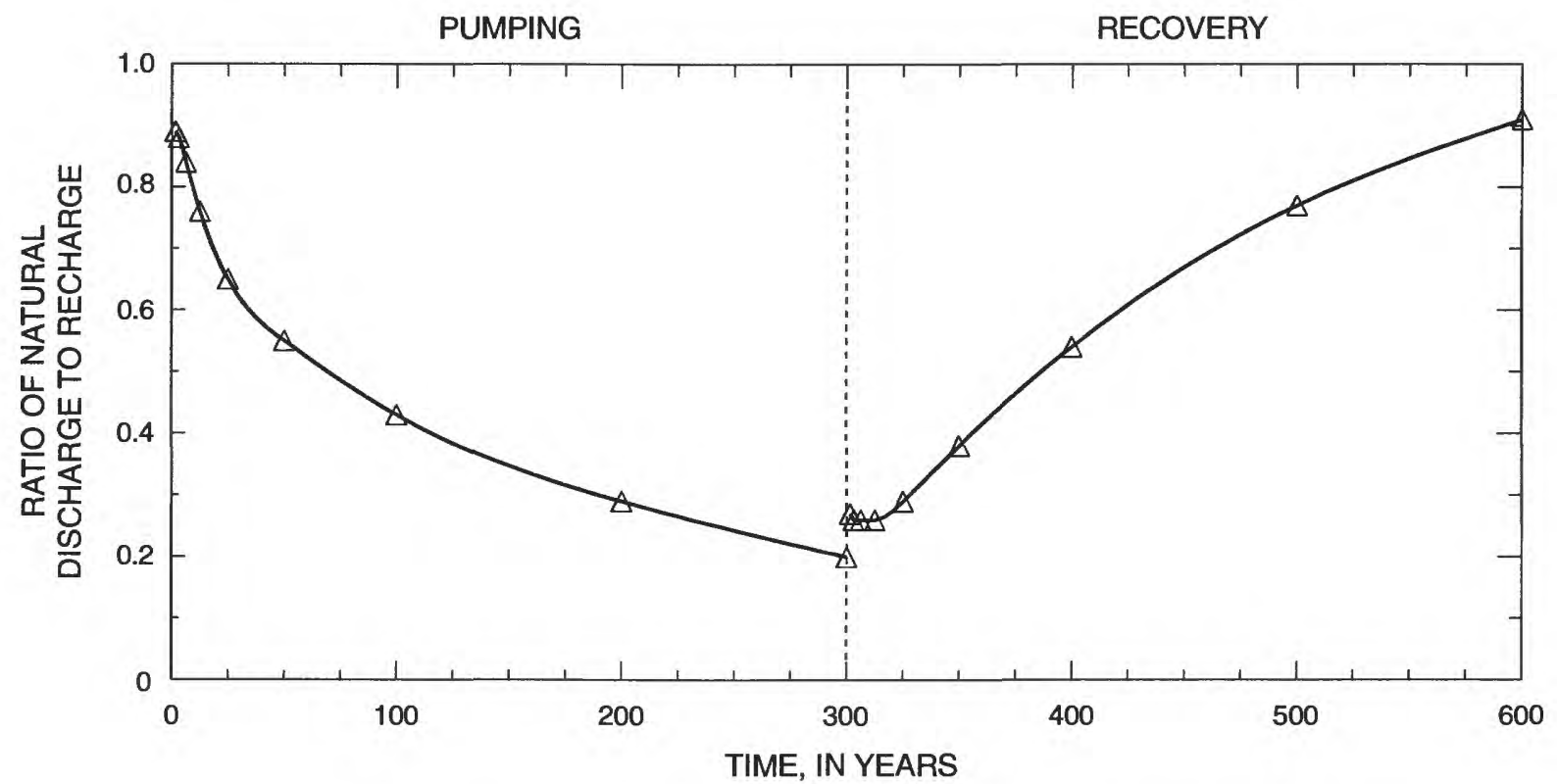

FIGURE 30.-Simulated change in the ratio of natural discharge to recharge during pumping and recovery for development alternative $\mathrm{A} 2$.

\section{DEVELOPMENT ALTERNATIVE B1}

In this development alternative, an entirely different approach was taken for distributing ground-water withdrawals. A trial-and-error method was used to find the pumping distribution most efficient at eliminating natural discharge. Knowledge gained from the previous development alternatives and the fact that evapotranspiration occurs throughout the length of the simulated area provided the basis for the initial distribution of groundwater withdrawals. After each simulation, the distribution of ground-water withdrawals was modified in order to eliminate evapotranspiration and to balance basin outflow with basin inflow at the northwest general-head boundary. The original constraints on ground-water withdrawals were maintained during the process.

The final distribution of ground-water withdrawals, which is one of many possible, used 96 cells distributed along the axis of the basin (fig. 37). This distribution coincides with the area of evapotranspiration as shown on plate 2. As in previous development alternatives, the net ground-water withdrawals equaled the estimated annual recharge. The cells had ground-water withdrawals ranging from $0.552 \mathrm{ft}^{3} / \mathrm{s}(400$ acre- $\mathrm{ft} / \mathrm{yr})$ to $1.104 \mathrm{ft}^{3} / \mathrm{s}(799$ acre-ft/yr). Ground-water withdrawals from cells near the southwest corner were necessary to eliminate evapotranspiration; and in all simulations using this distribution, the adjacent general-head boundary was affected immediately, thus increasing basin inflow. Ground-water withdrawals were simulated in cells near the northwest general-head boundary for the purpose of balancing basin outflow with inflow.

After 300 years of pumping, cones of depression had developed in the north and the southwest corners of the basin with a discernible trough along the axis of the basin (fig. 38). The maximum water-level decline was more than $60 \mathrm{ft}$ and the average water-level decline was almost $45 \mathrm{ft}$ (fig. 39). The general-head boundaries were affected immediately because of the strategically placed groundwater withdrawals (fig. 40).

Unlike previous development alternatives, strategically placed ground-water withdrawals resulted in distributed water-level declines throughout the basin, thus maximizing the area for potential recharge when pumping ceased. During recovery, more water initially went into storage (fig. 41), thus allowing water levels to rise rapidly and recovery to be more complete; however, like the development alternatives $\mathrm{A} 2$ and $\mathrm{A} 3$, which have ground-water withdrawals in the north, residual waterlevel declines are present only in the northern one-half of the basin with maximum residual water-level declines of more than $5 \mathrm{ft}$ in the extreme northeast corner (fig. 42).

This development alternative was efficient at capturing natural discharge with most of the decrease occurring in the first 50 years of pumping (fig. 43). By the end of 300 years of pumping, 89 percent of the natural discharge had 


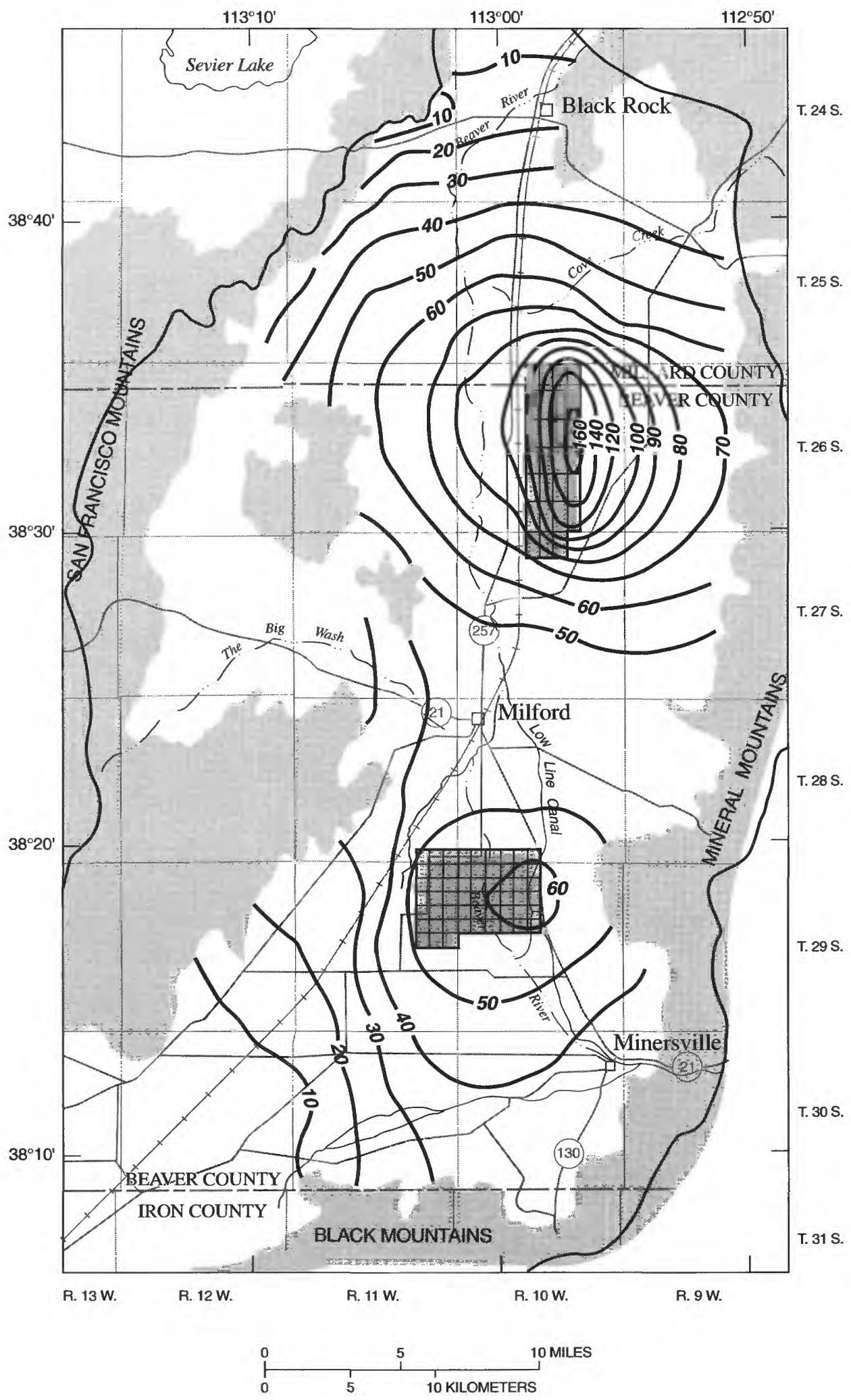

EXPLANATION

Consolidated rocks

Basin fill

Cell simulating pumping

- 70 - Line of equal water-level decline after 300 years of pumping - Interval is 10 and 20 feet

Boundary of study area

$26 \mathrm{~S}$.

$27 \mathrm{~S}$.

$28 \mathrm{~S}$.

$29 \mathrm{~S}$.

$30 \mathrm{~S}$.

$31 \mathrm{~S}$.

FIGURE 31.-Simulated water-level declines after 300 years of pumping and areal distribution of cells simulating pumping for development alternative $\mathrm{A} 3$. 


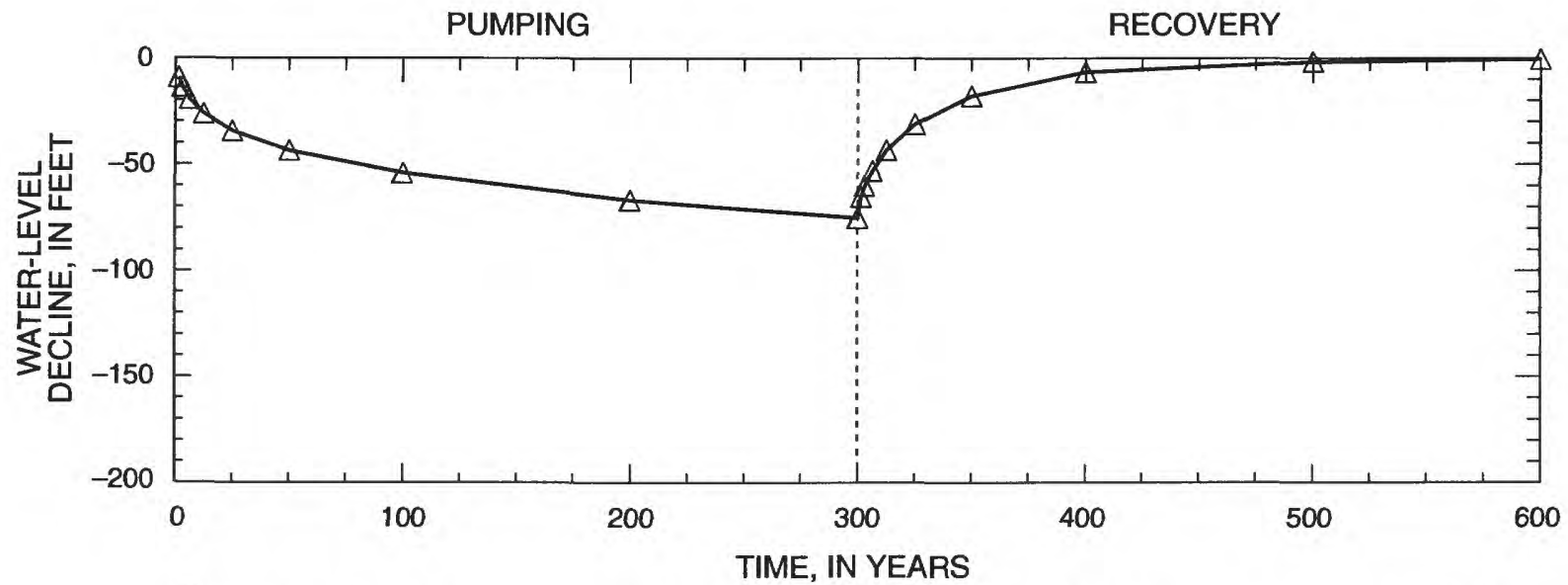

FIGURE 32.-Simulated average water-level decline and recovery in model cells containing pumped wells for development alternative $\mathrm{A} 3$.

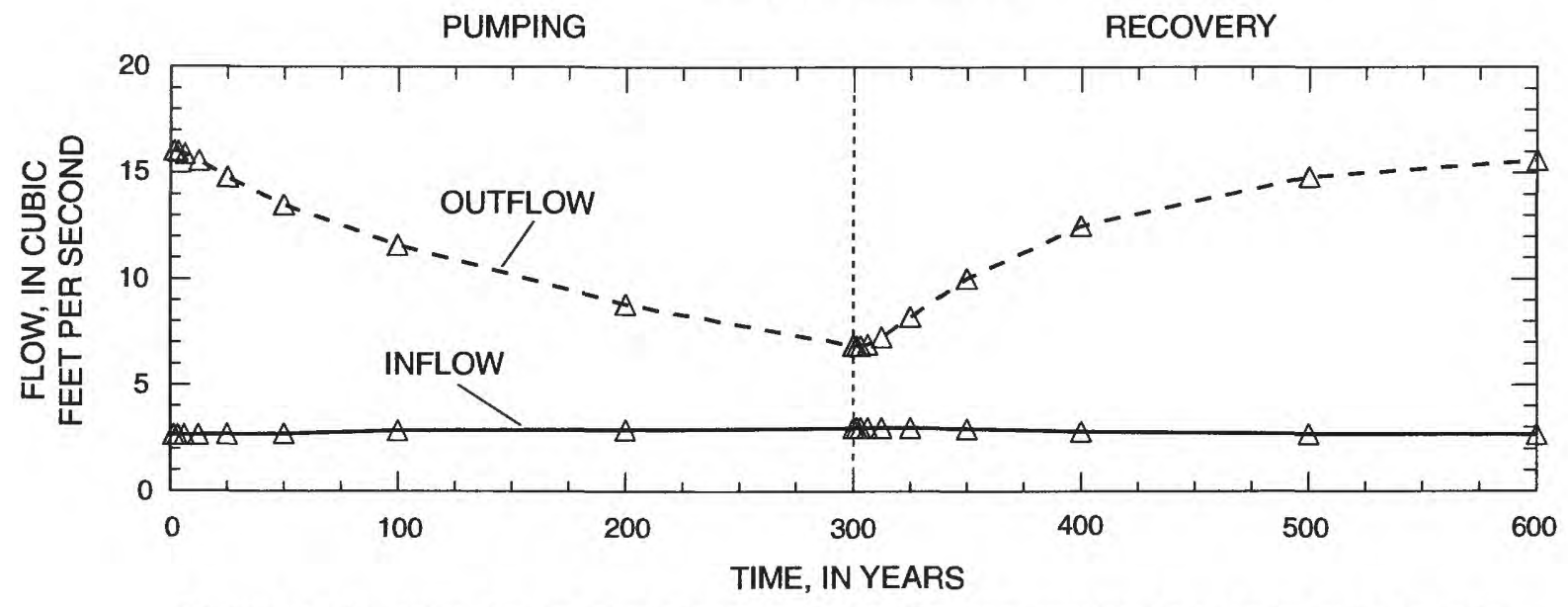

FIGURE 33.- Simulated changes in basin inflow and net outflow at general-head boundaries during pumping and recovery for development alternative $\mathrm{A} 3$.

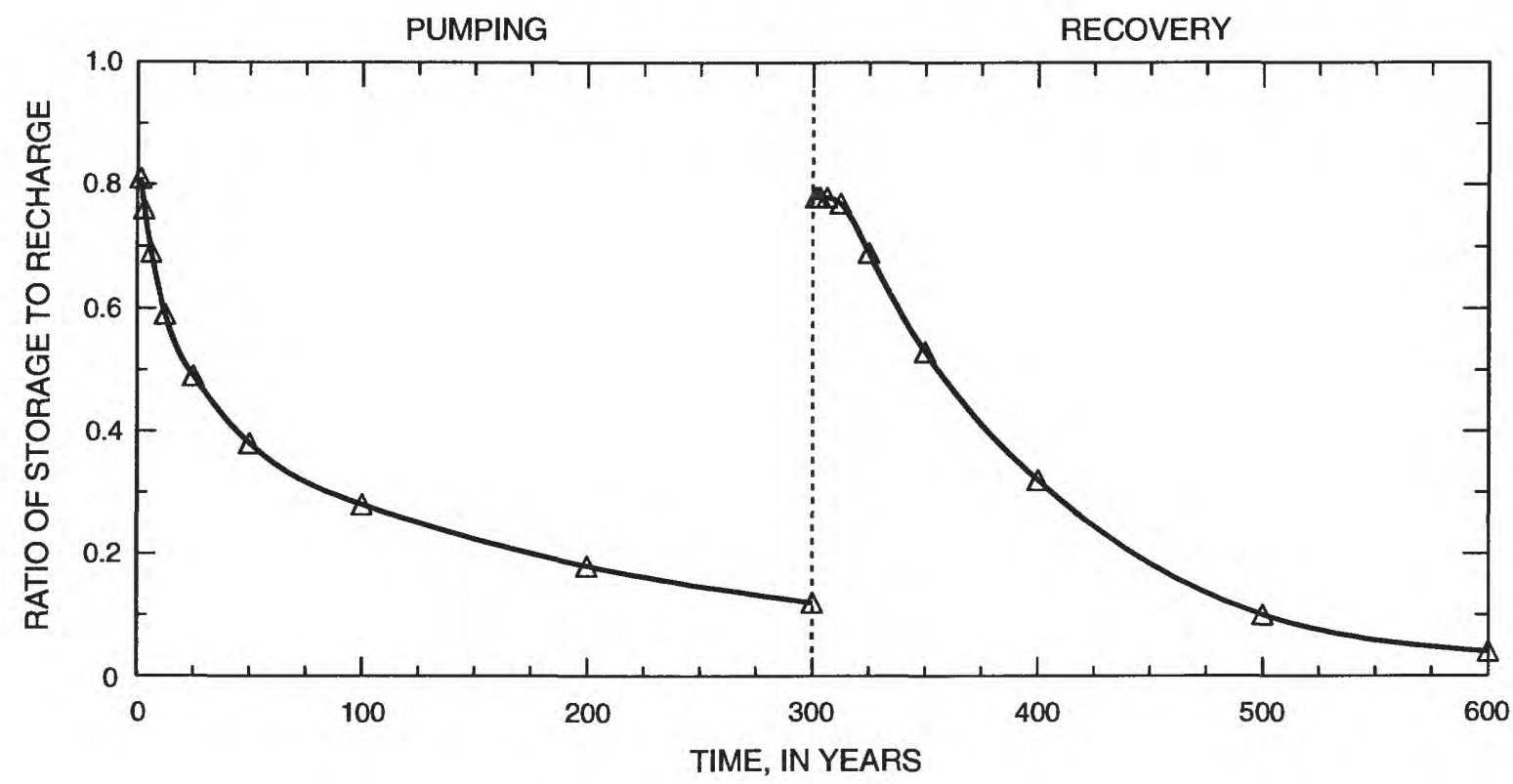

FIGURE 34.-Simulated changes in the ratios of water removed from storage during pumping to recharge and water added to storage during recovery to recharge for development alternative $\mathrm{A} 3$. 


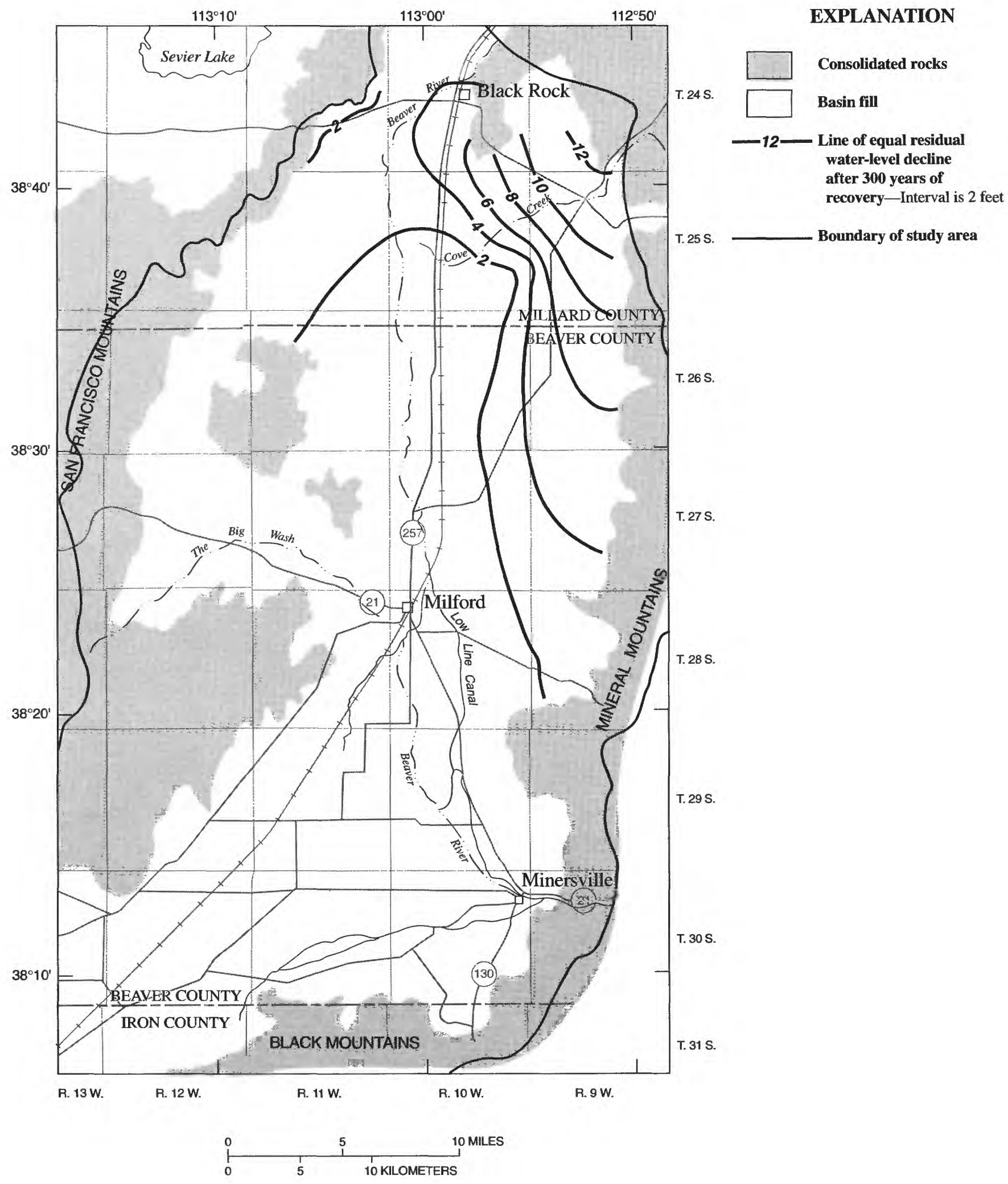

FIGURE 35.-Simulated residual water-level declines after 300 years of recovery for development alternative A3. 


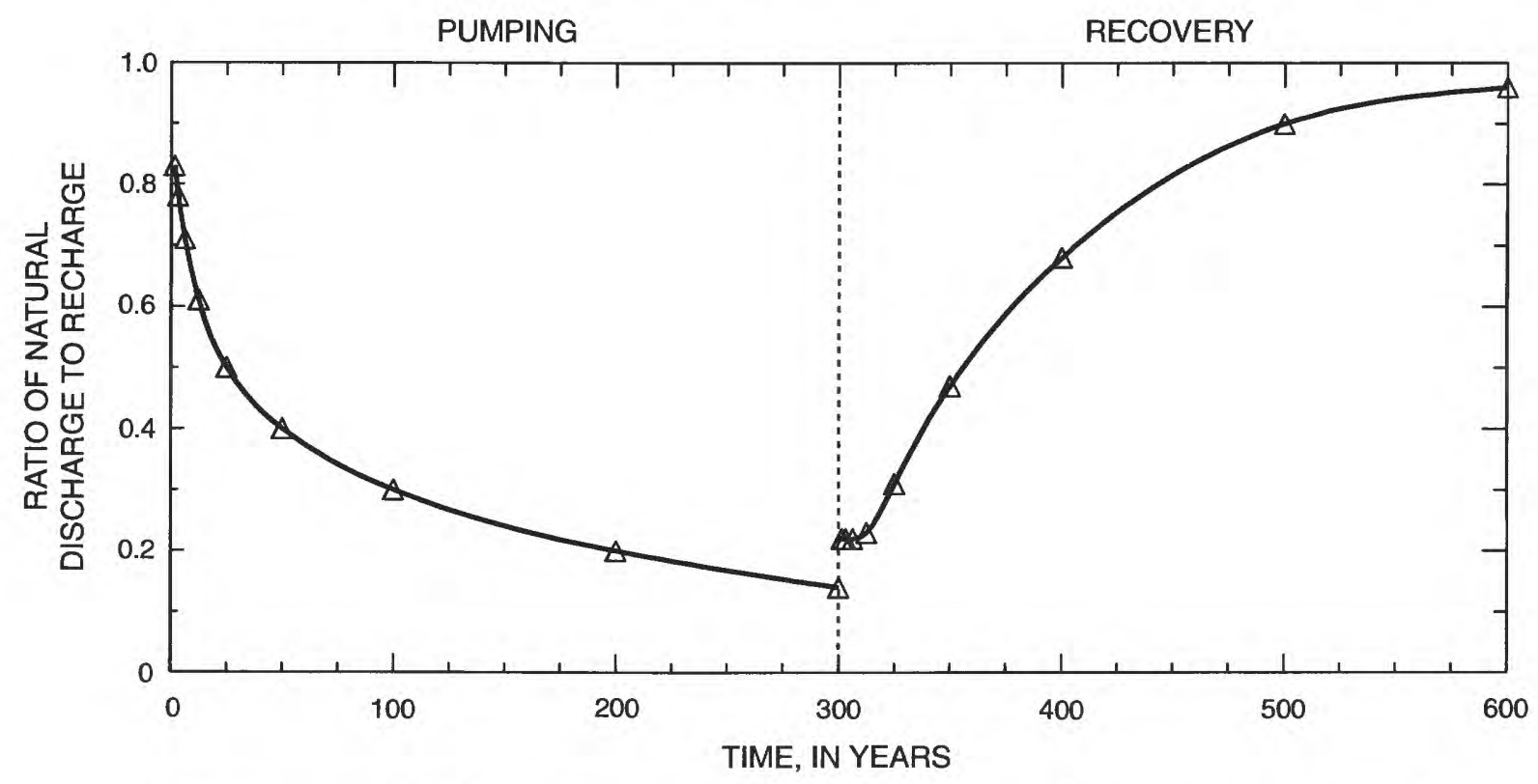

FIGURE 36.-Simulated change in the ratio of natural discharge to recharge during pumping and recovery for development alternative A3.

been eliminated. Evapotranspiration had ceased, thereby leaving net basin outflow as the only form of natural discharge. The ground-water system approached a new equilibrium after 200 years. For the remaining 100 years of pumping, there was no substantial change in the quantity of water removed from storage. Similarly, recovery was rapid with most of it occurring in the first 100 years.

\section{DEVELOPMENT ALTERNATIVE B2}

This development alternative uses the same distribution of withdrawals as development alternative B1 but increases the net ground-water withdrawals by a factor of 1.25. Originally, this simulation used a factor of 1.5 ; but cells in the upper layer near the northwest general-head boundary began to go dry after 100 years of pumping. After several cells had gone dry, they became inactive for the remainder of the simulation, including the recovery period; therefore, the simulation could not approximate the response of the ground-water system to the hypothetical stress. By using the smaller increase, this problem was not encountered.

As in development alternative B1, a well-defined cone of depression developed in the southwest corner of the basin, with water-level declines of more than $70 \mathrm{ft}$ after 300 years of pumping (fig. 44). A broad trough developed through the center of the area with maximum declines of more than $90 \mathrm{ft}$ in the north and $80 \mathrm{ft}$ in the south. The average water-level decline was more than $80 \mathrm{ft}$ within the entire pumped area (fig. 45). Substantial water-level declines were present at all boundaries. The general-head boundaries were affected immediately and changes in the rate of basin inflow and outflow continued throughout the pumping period (fig. 46).

Due to the broad area of water-level declines and large quantities of water removed from storage, almost 50 years of recovery were necessary before substantial quantities of water went into storage (fig. 47). After 300 years of recovery, residual water-level declines were less than 2 $\mathrm{ft}$ throughout most of the area (fig. 48). As in previous development alternatives that pumped from the north part of the basin, substantial residual water-level declines were present in the northeast corner.

The ratio of storage versus recharge declined drastically during the first 50 years of pumping (fig. 47). During the remaining 250 years, this ratio continued to decline, but at a much slower rate. Eighty-six percent of the natural discharge was eliminated after 100 years with most of the remaining 14 percent eliminated in the last 200 years of pumping (fig. 49). By comparing the ratios of storage and natural discharge to recharge, it is apparent that as natural discharge was eliminated, less water was removed from storage.

\section{DEVELOPMENT ALTERNATIVE B3}

In the final development alternative, ground-water withdrawals were varied during the pumping phase. For the first 50 years, the applied stress was 1.75 times the estimated annual recharge, and was held equal to re- 


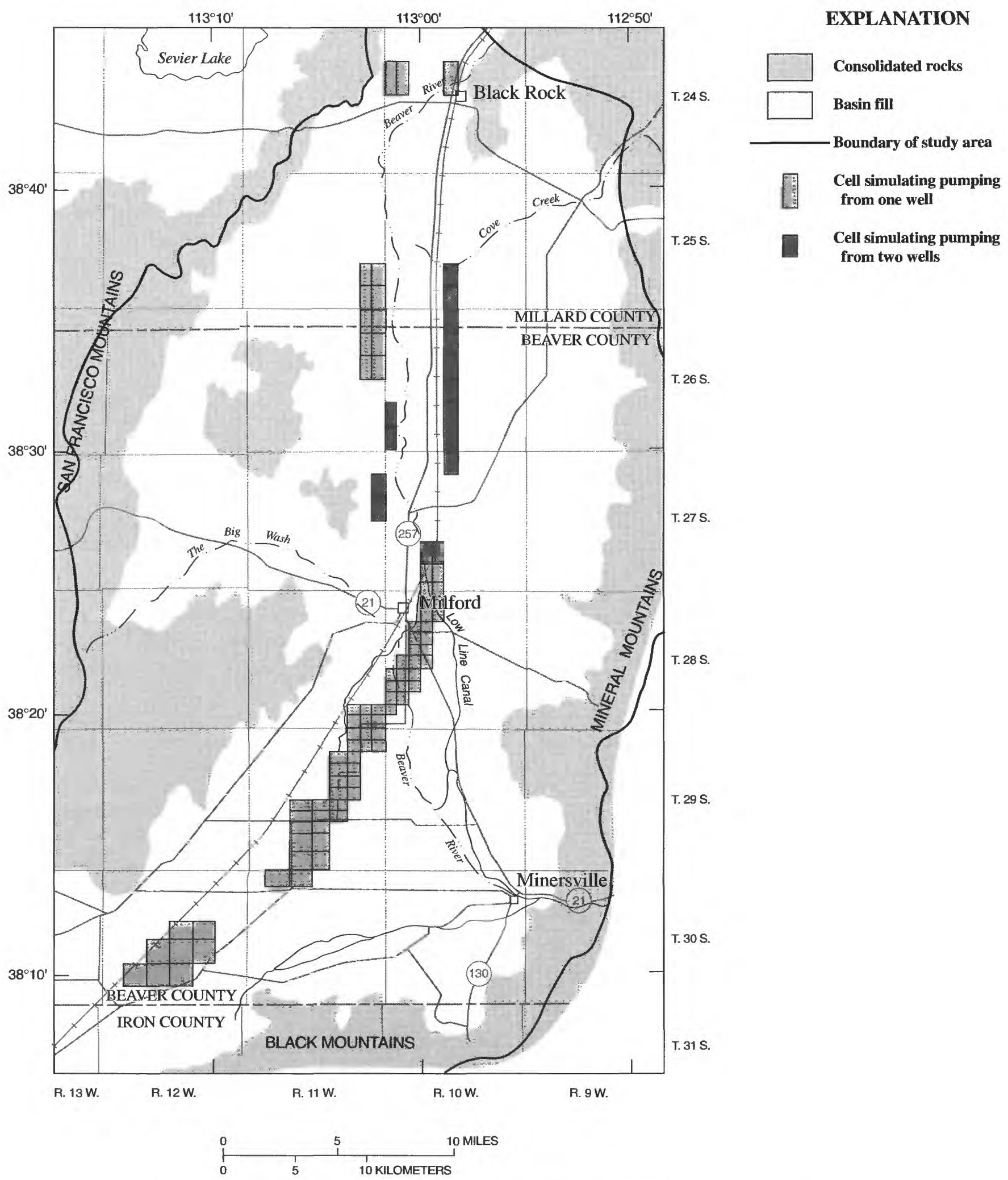

FIGURE 37.-Areal distribution of cells simulating pumping for development alternatives B1, B2, and B3. 


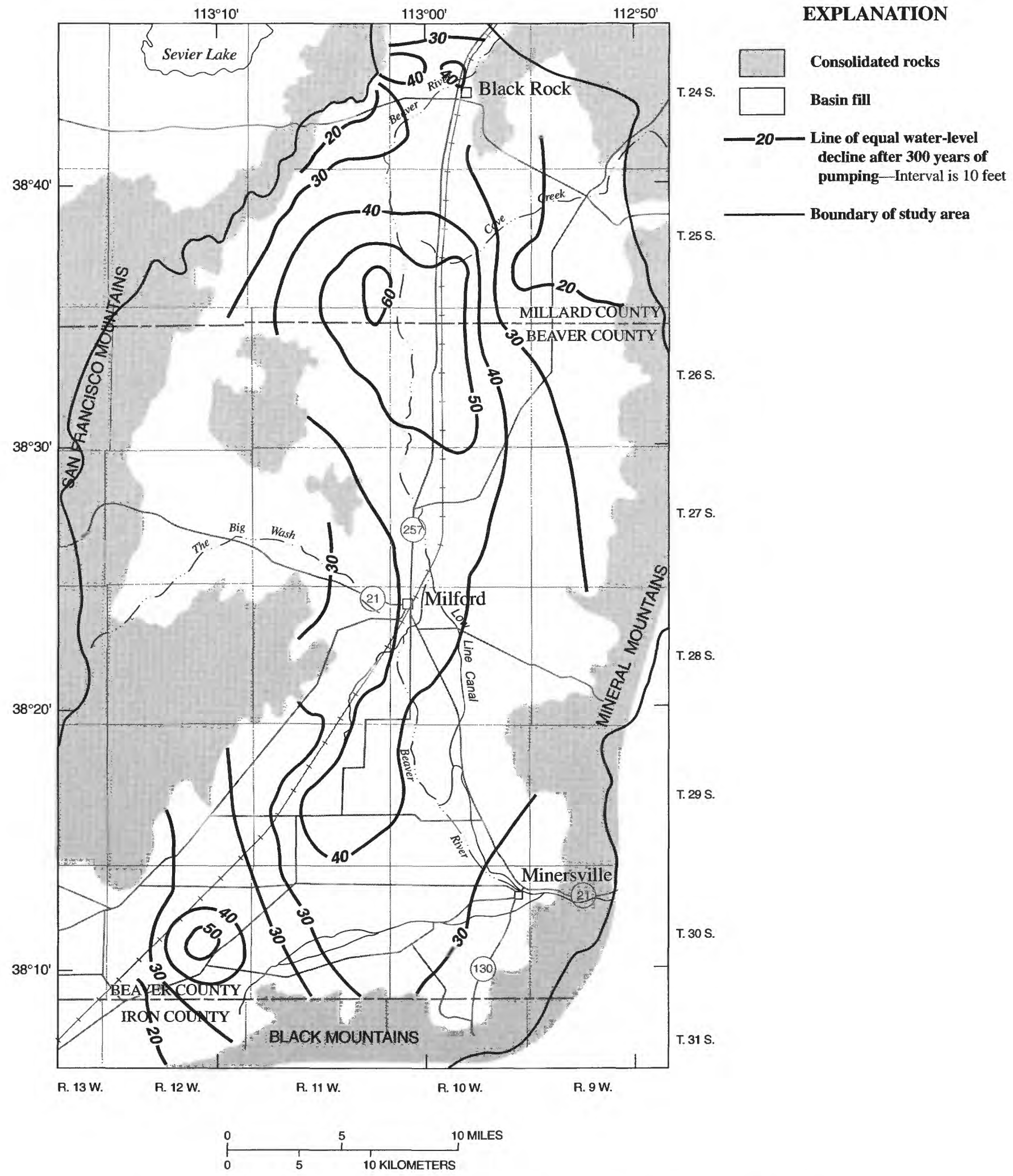

FIGURE 38.-Simulated water-level declines after 300 years of pumping for development alternative B1. 


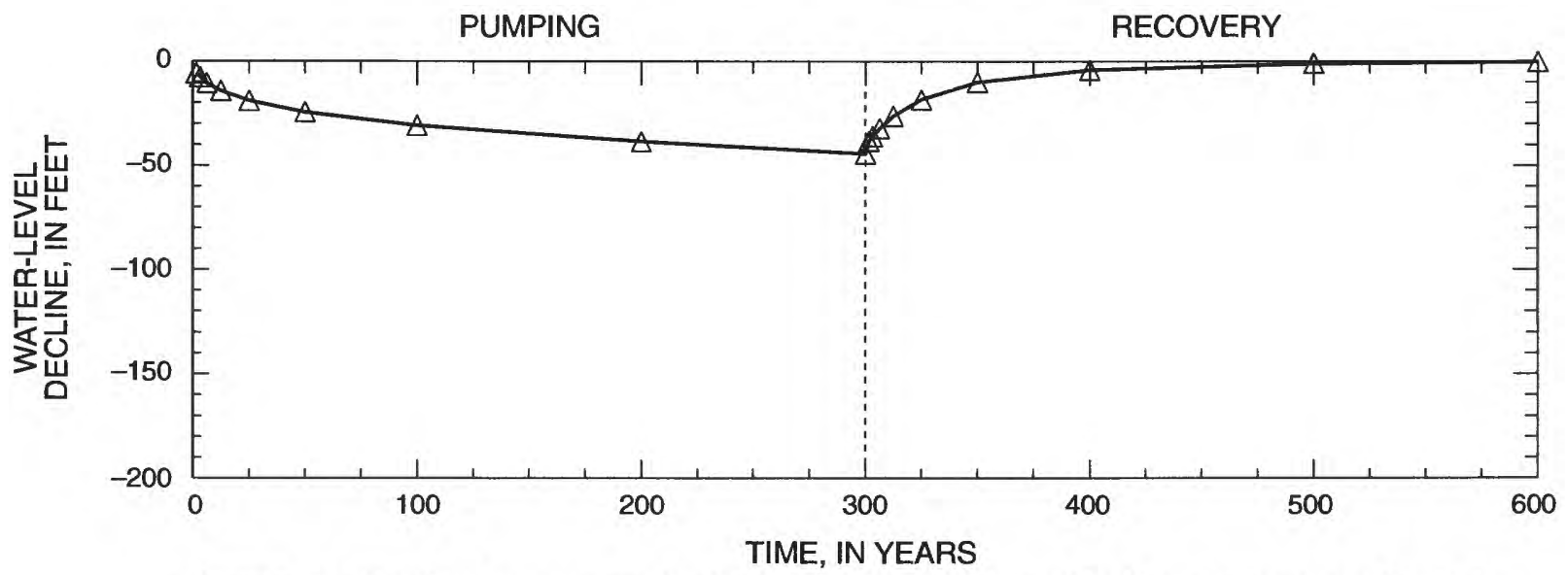

FIGURE 39.- Simulated average water-level decline and recovery in model cells containing pumped wells for development alternative B1.

PUMPING

RECOVERY

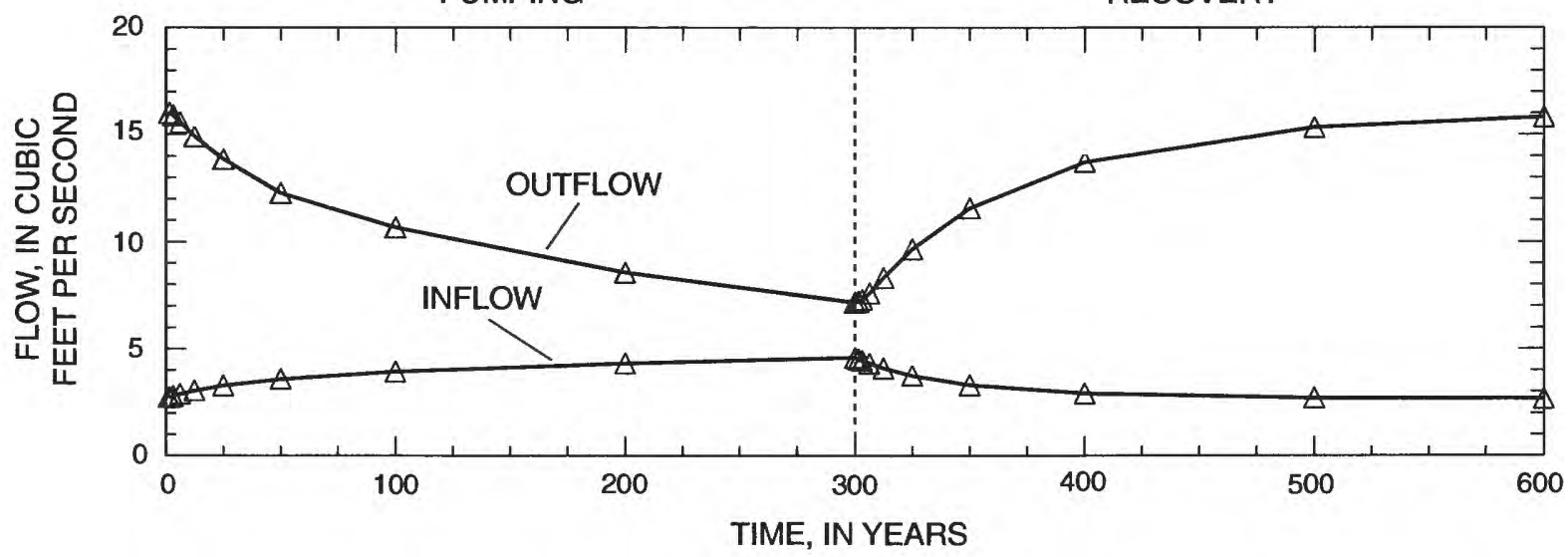

FIGURE 40.-Simulated changes in basin inflow and net outflow at general-head boundaries during pumping and recovery for development alternative $\mathrm{B} 1$.

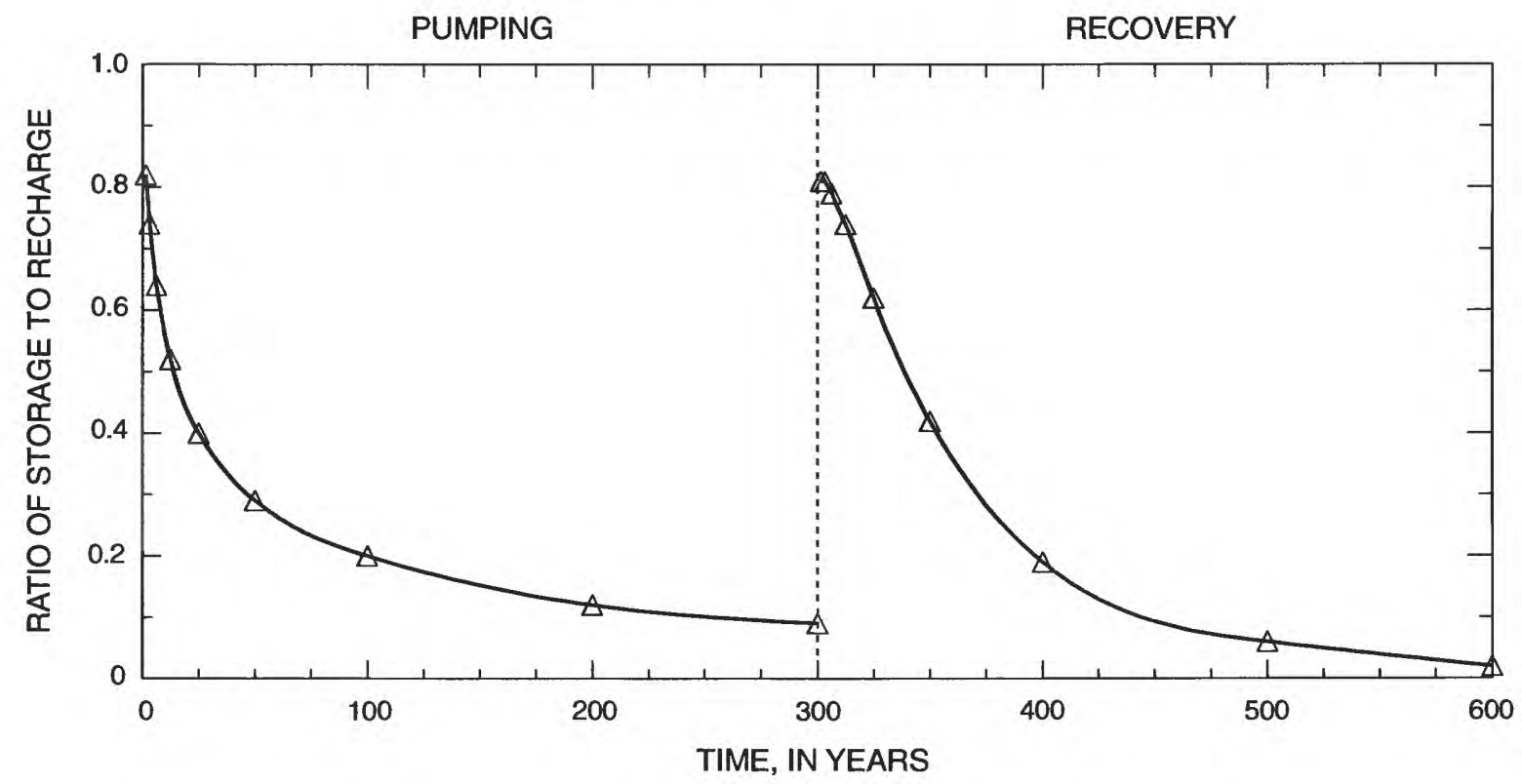

FIGURE 41.-Simulated changes in the ratios of water removed from storage during pumping to recharge and water added to storage during recovery to recharge for development alternative B1. 


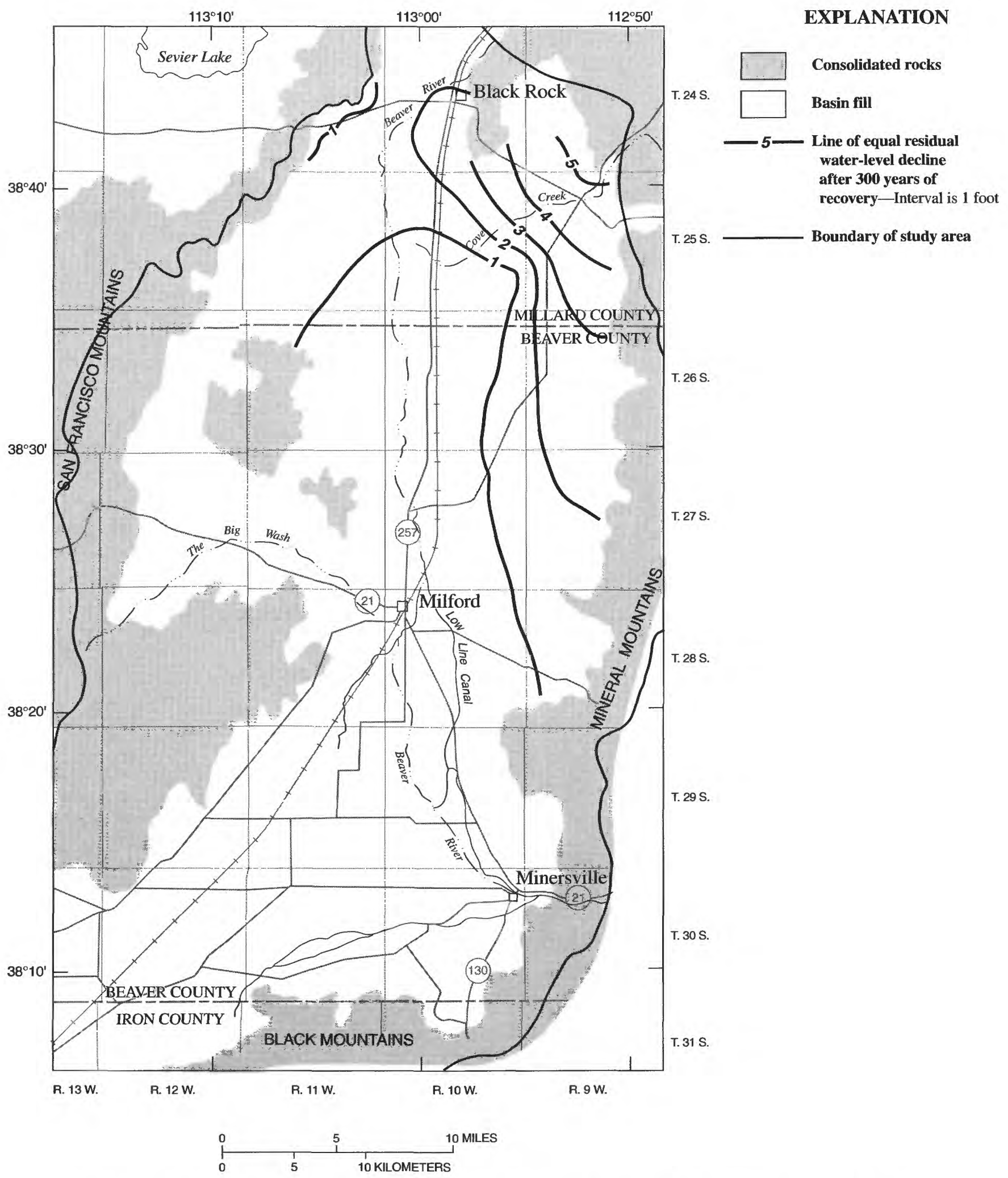

FIGURE 42.-Simulated residual water-level declines after 300 years of recovery for development alternative B1. 


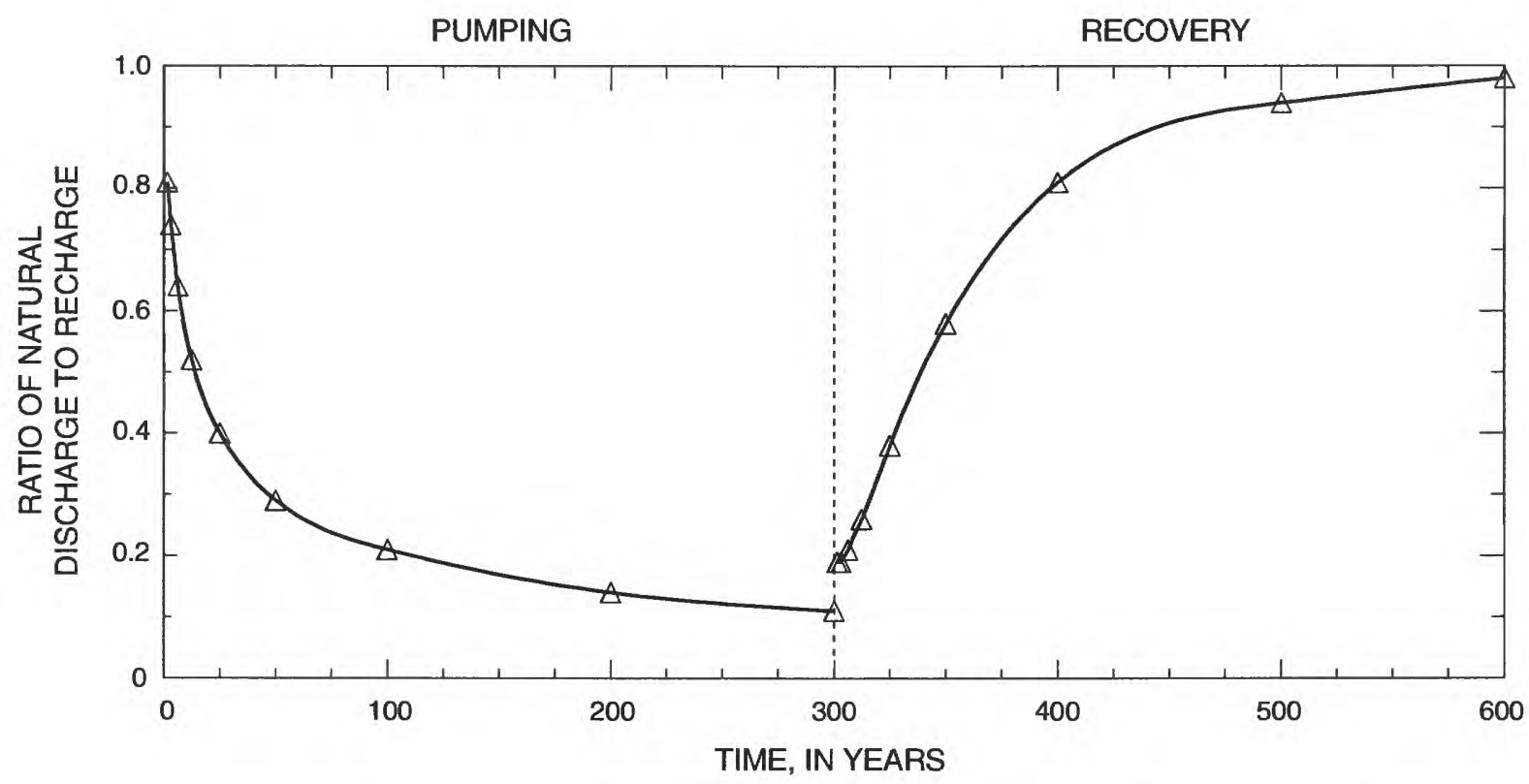

FIGURE 43.-Simulated change in the ratio of natural discharge to recharge during pumping and recovery for development alternative B1.

charge for the remaining 250 years. The same distribution of ground-water withdrawals derived for development alternative B1 was used. The response of the groundwater system to this hypothetical stress was quite different compared to the previous development alternatives.

As in development alternatives B1 and B2, a welldefined cone of depression, with water-level declines of more than $50 \mathrm{ft}$, developed in the southwest corner of the area. In this case, however, the cone of depression developed after only 50 years of pumping (fig. 50). An elongate trough of water-level declines developed along the axis of the basin with maximum declines of more than $60 \mathrm{ft}$ in three separate areas. Water-level declines developed along all basin boundaries. A small trough of water-level declines developed in the extreme north end of the basin near Black Rock. Under actual conditions, water-level declines in that area probably would be less because the basalt near Black Rock could provide more water than the constant flux allowed in these simulations.

When the net ground-water withdrawals were reduced, the average water level rose in the pumped cells for the next 50 years and then stabilized for the remaining 200 years (fig. 51). Similarly, effects at both general-head boundaries stabilized after the first 50 years (fig. 52). After the full 300 years of pumping, the computed waterlevel declines (fig. 53) are different from the computed water-level declines after 50 years of pumping. Although water levels rose in the southern one-half of the basin, the cone of depression in the southwest corner remained well defined. Similarly, water-level declines at the southern boundaries were reduced. In contrast, water levels continued to decline throughout the northern one-half of the basin. Although the maximum water-level decline did not decrease substantially, the effects of continued pumping at the reduced rate can be seen by the increased waterlevel declines at the northern basin boundaries. The continued water-level declines are due to smaller transmissivity values and less recharge compared to the southern one-half of the basin.

Initially, the quantity of water removed from storage was large; but, after 25 years, it began to stabilize. When the net ground-water withdrawals were reduced for the remaining 250 years, the quantity of water removed from storage decreased drastically with the net change in storage approaching zero (fig. 54). With partial recovery in the last 250 years of pumping, water levels were able to recover more rapidly after pumping ceased. As shown in figure 55, most of the area recovered to within $1 \mathrm{ft}$ of the original water levels. Residual water-level declines of more than $6 \mathrm{ft}$ are found in the extreme northeast corner of the basin.

In the first 50 years of the simulation, natural discharge was captured efficiently, eliminating 86 percent. For the remainder of the pumping period, only another 5 percent of the natural discharge was eliminated (fig. 56). After 200 years, all evapotranspiration had ceased, thus natural discharge for the remaining 100 years was composed entirely of net basin outflow. After 50 years, with natural discharge mostly captured and ground-water withdrawals reduced to a quantity equal to recharge, 


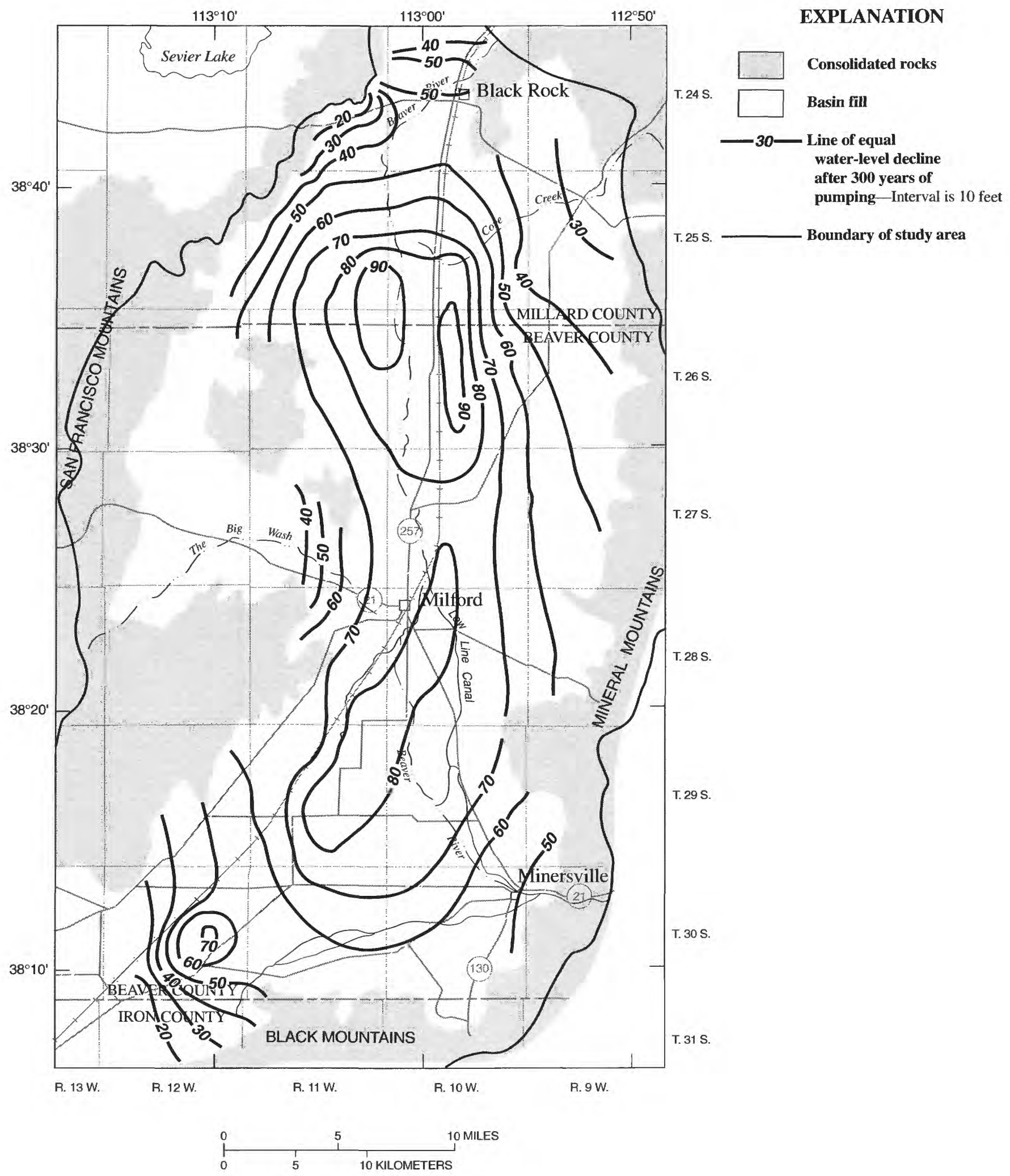

FIGURE 44.-Simulated water-level declines after 300 years of pumping for development alternative B2. 


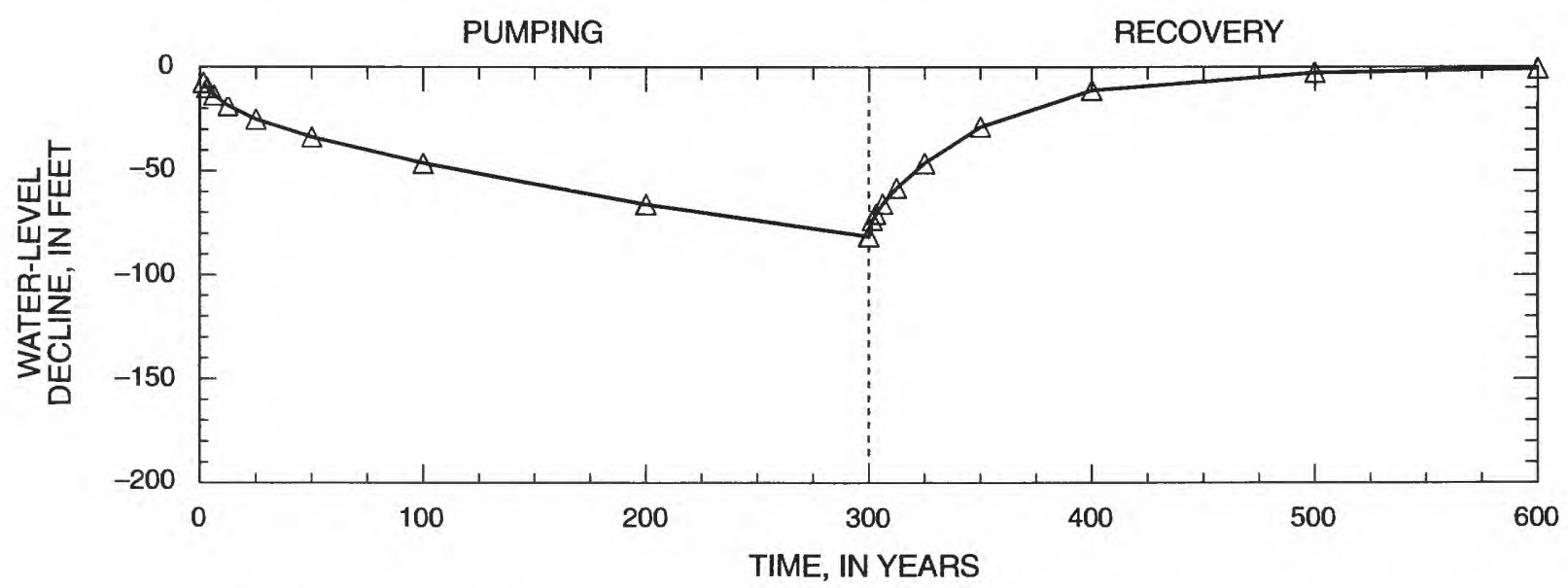

FIGURE 45.-Simulated average water-level decline and recovery in model cells containing pumped wells for development alternative $\mathrm{B} 2$.

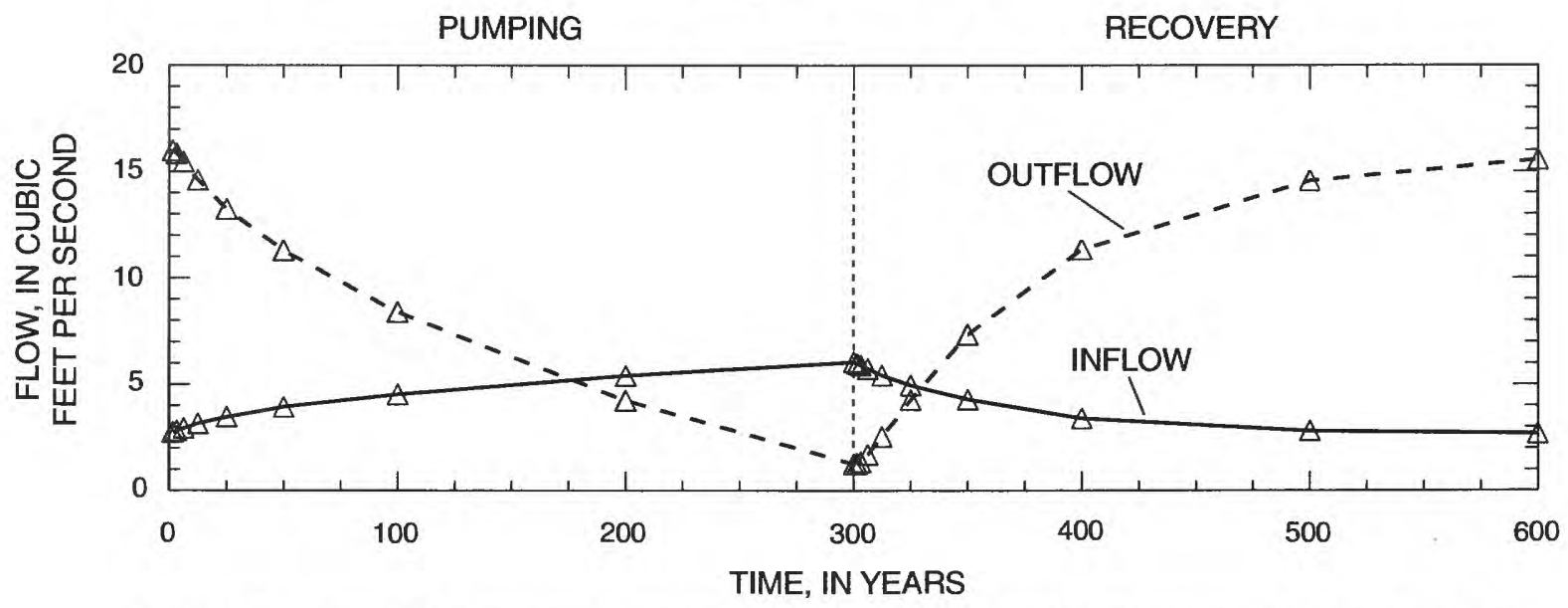

FIGURE 46.-Simulated changes in basin inflow and net outflow at general-head boundaries during pumping and recovery for development alternative $\mathrm{B} 2$.

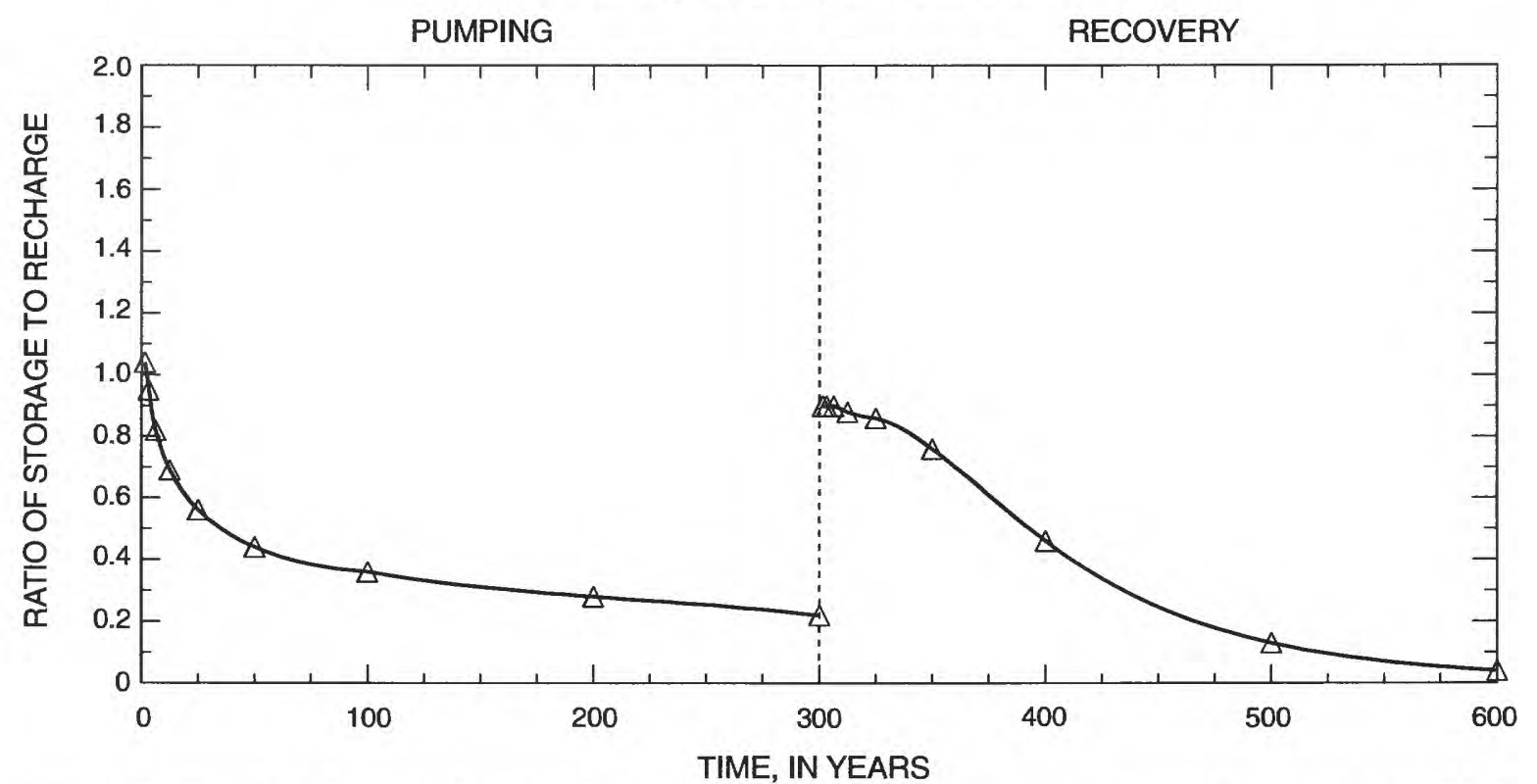

FIGURE 47.-Simulated changes in the ratios of water removed from storage during pumping to recharge and water added to storage during recovery to recharge for development alternative B2. 


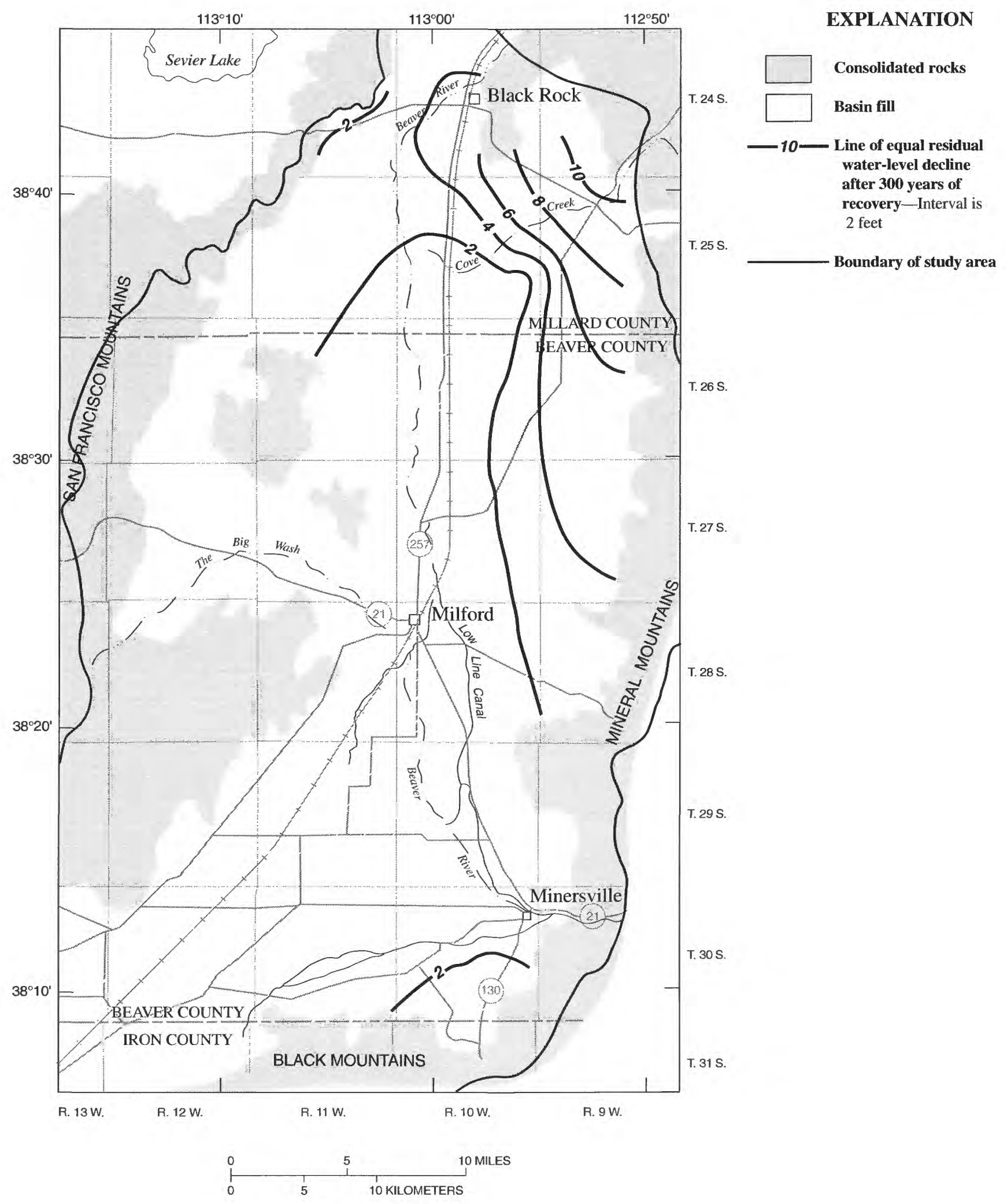

FIGURE 48.-Simulated residual water-level declines after 300 years of recovery for development alternative B2. 


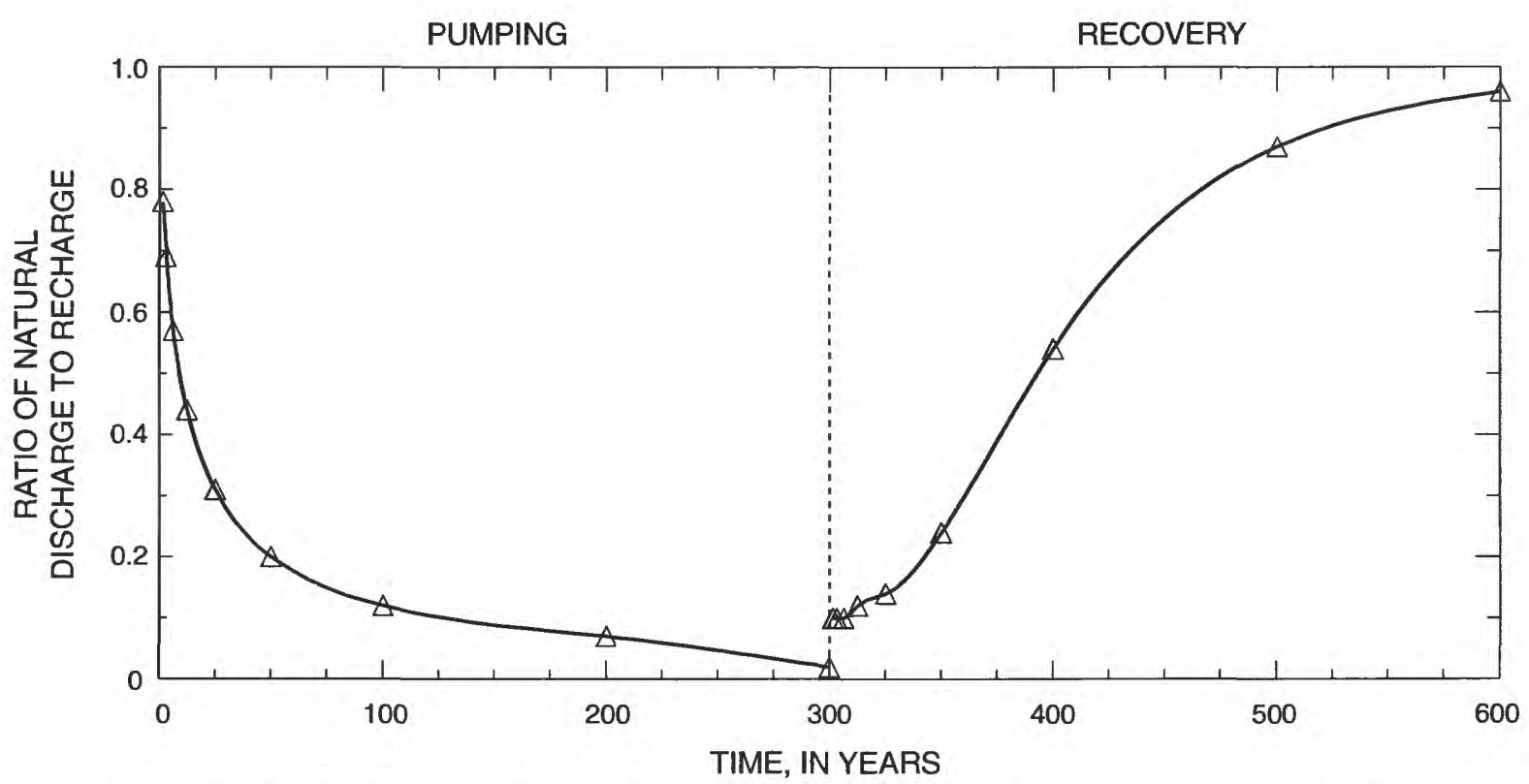

FIGURE 49.-Simulated change in the ratio of natural discharge to recharge during pumping and recovery for development alternative $B 2$.

water removed from storage was about equal to the quantity of water exiting the basin through the general-head boundary.

\section{EVALUATION OF DEVELOPMENT ALTERNATIVES}

Four different distributions of ground-water withdrawals were used in "sustained"-yield simulations to determine (1) their efficiency in reducing or eliminating natural discharge, (2) their effect on water-level declines, and (3) their residual effects on water-level recoveries and resumption of natural discharge after pumping ceased. Two additional simulations tested the effects of groundwater withdrawals greater than the average annual recharge.

All development alternatives resulted in declining water levels and reduced natural discharge during pumping; but in most cases, water levels and natural discharge recovered to near pre-pumping conditions after pumping had ceased. The extent of water-level declines and the rate of reduction of natural discharge was most dependent on the areal distribution of withdrawals. Because increased pumping above average annual recharge goes beyond the concept of "sustained" yield, variations in the rate of pumping were not tested for development alternatives that have concentrated pumping centers. Increasing the rate of pumping for these development alternatives would have formed deeper cones of depression and would not have decreased natural discharge substantially.
During the 300-year recovery phase, the rates at which water levels recovered and natural discharge increased were dependent on (1) the areal distribution of ground-water withdrawals relative to recharge boundaries, (2) the areal distribution of transmissivity, and (3) the quantity of water removed from storage.

"Sustained"-yield simulations involving concentrated pumping centers (development alternatives A1, A2, and $\mathrm{A} 3$ ) were least effective in reducing natural discharge, and formed well-defined cones of depression with large water-level declines. Development alternatives $\mathrm{A} 1$ and $\mathrm{A} 2$ had the largest water-level declines and the largest amount of water removed from storage (table 5). Development alternative A1, with its concentrated pumping center in the southern one-half of the basin area, had the advantage of larger transmissivity values in the pumped area and closer proximity to the main sources of recharge than alternative $\mathrm{A} 2$ with its pumping center in the north; therefore, water-level declines were less and recovery was faster for development alternative A1. Because natural discharge occurs throughout the basin area, neither development alternative $\mathrm{A} 1$ or $\mathrm{A} 2$ were completely effective in reducing natural discharge. Development alternative $\mathrm{A} 3$, which equally divided pumping between two centers, began to approach the optimum development pattern by more effectively reducing natural discharge, coupled with smaller water-level declines and less water removed from storage. These conditions allowed for faster recovery after pumping ceased. 


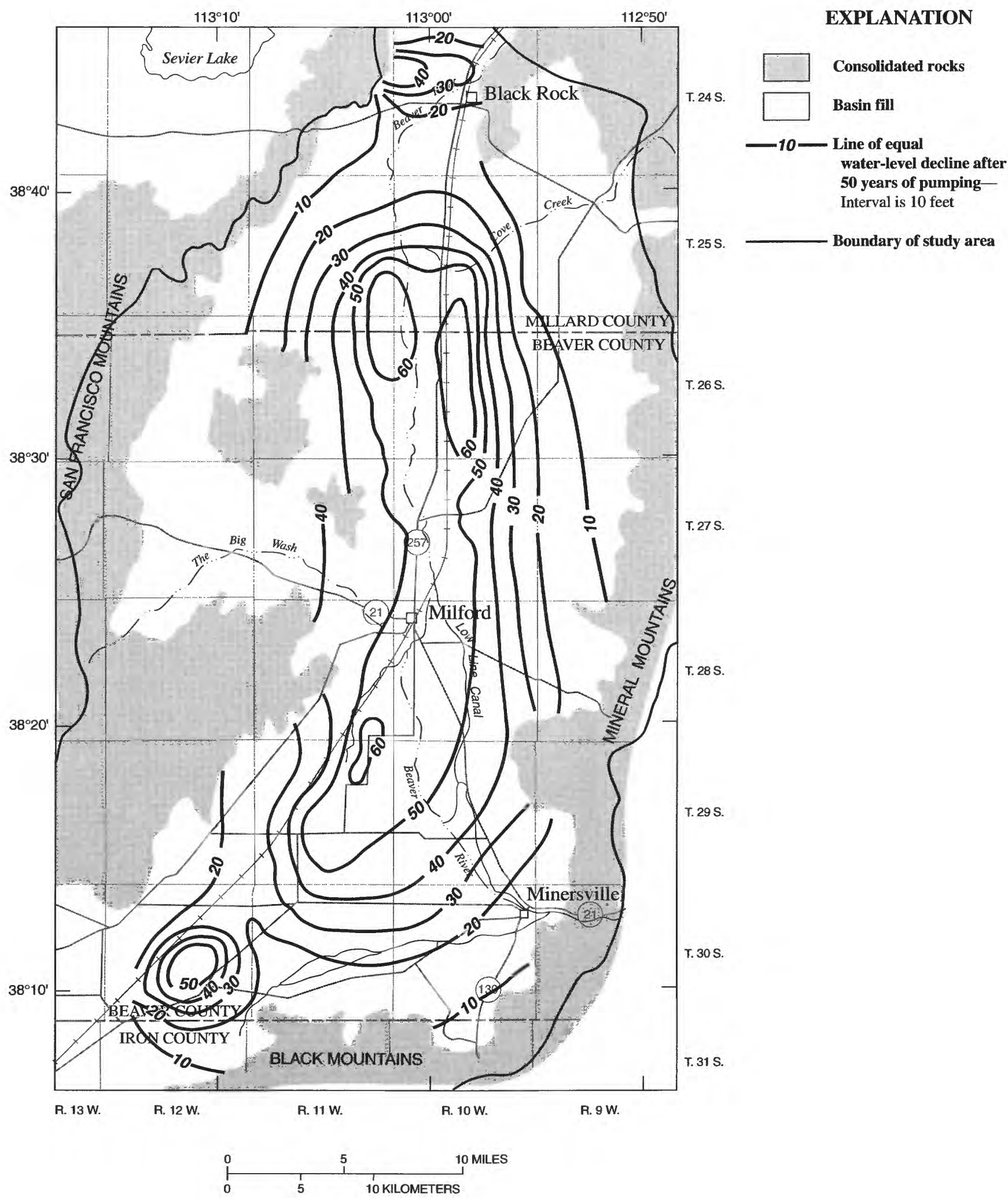

FIGURE 50.-Simulated water-level declines after 50 years of pumping for development alternative B3. 


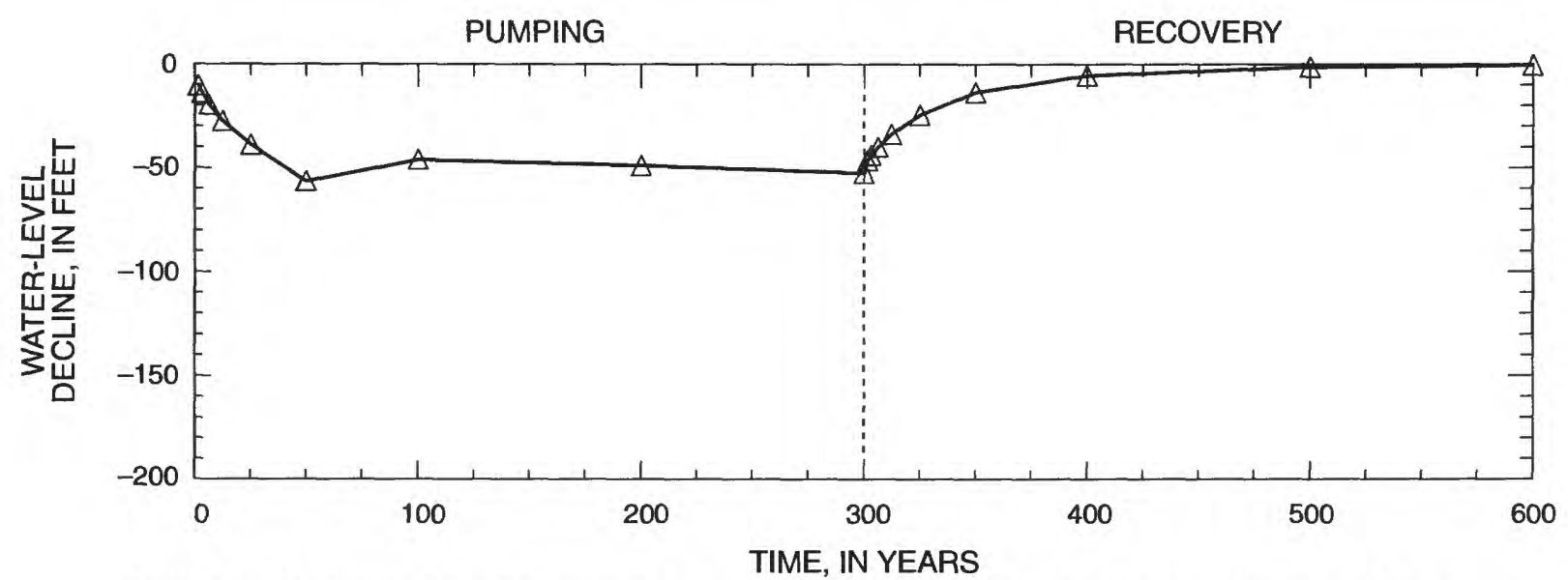

FIGURE 51.-Simulated average water-level decline and recovery in model cells containing pumped wells for development alternative $\mathrm{B} 3$.

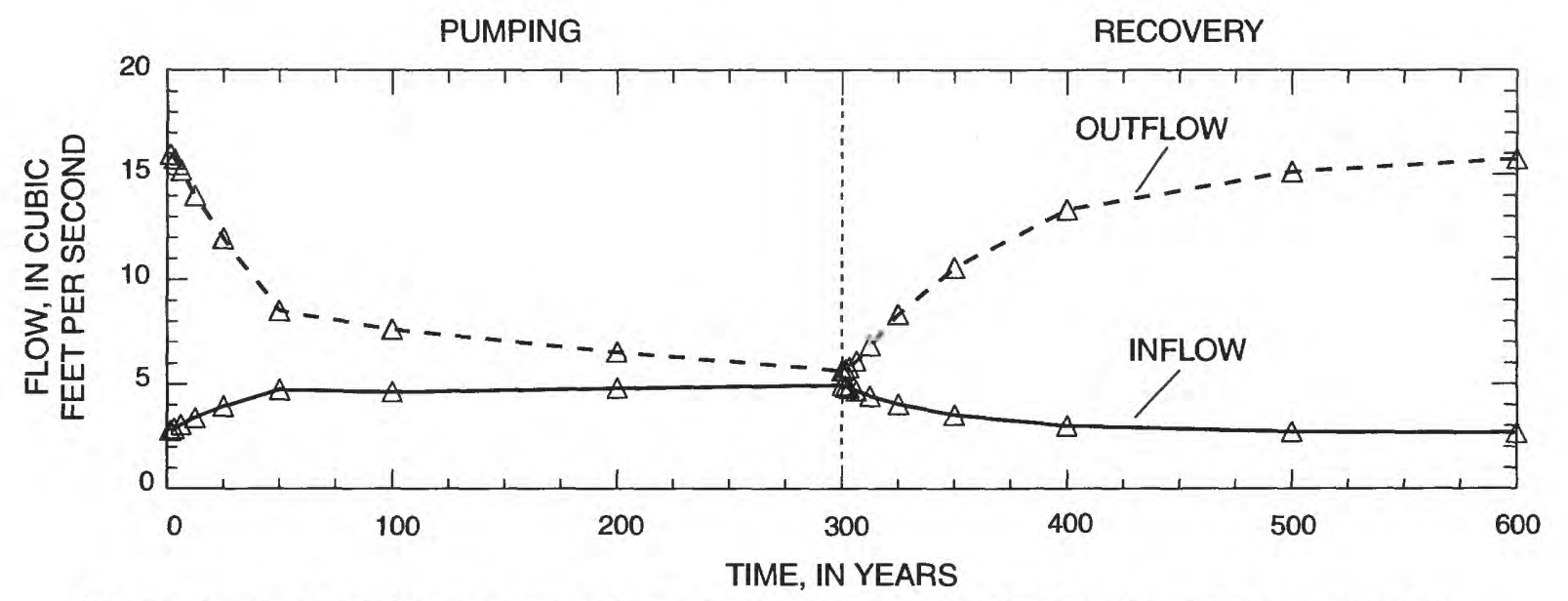

FIGURE 52.-Simulated changes in basin inflow and net outflow at general-head boundaries during pumping and recovery for development alternative $\mathrm{B} 3$.

A development alternative with withdrawals strategically distributed, such as development alternative B1, proved to be the most effective in reducing natural discharge, eliminating 89 percent of the total evapotranspiration and basin outflow as the ground-water system approached a new equilibrium. This was accomplished with minimal water-level declines throughout the basin and the least amount of water removed from storage (table 5). By removing ground water normally lost to evapotranspiration and basin outflow, the ground-water system was not substantially depleted, thus allowing for rapid recovery.

Development alternatives B2 and B3 provided some insight into the effects of ground-water mining by withdrawing more ground water than the average annual recharge. Net ground-water withdrawals for development alternative B2 were 1.25 times larger than the estimated average annual recharge for the basin. This development alternative almost eliminated natural dis- charge after 200 years of pumping, but it also produced water-level declines throughout the basin, especially in the north. Pumping at a large rate for the first 50 years, such as development alternative B3, proved to be effective in eliminating natural discharge in a short time. When the pumping rate was reduced to the estimated average annual recharge for the remaining 250 years of pumping, water levels partially recovered and then stabilized. This development alternative had two additional advantages: (1) it removed virtually no water from storage after the first 100 years of pumping, and (2) it produced the second smallest water-level declines after the full 300 years of pumping. Along with development alternative $\mathrm{B} 1$, this alternative could be another viable development option for the beneficial use of ground water before it is consumed by evapotranspiration or is lost by flowing out of the basin, despite the initial disadvantage of large water-level declines that might promote the compaction of sediments and land subsidence. 


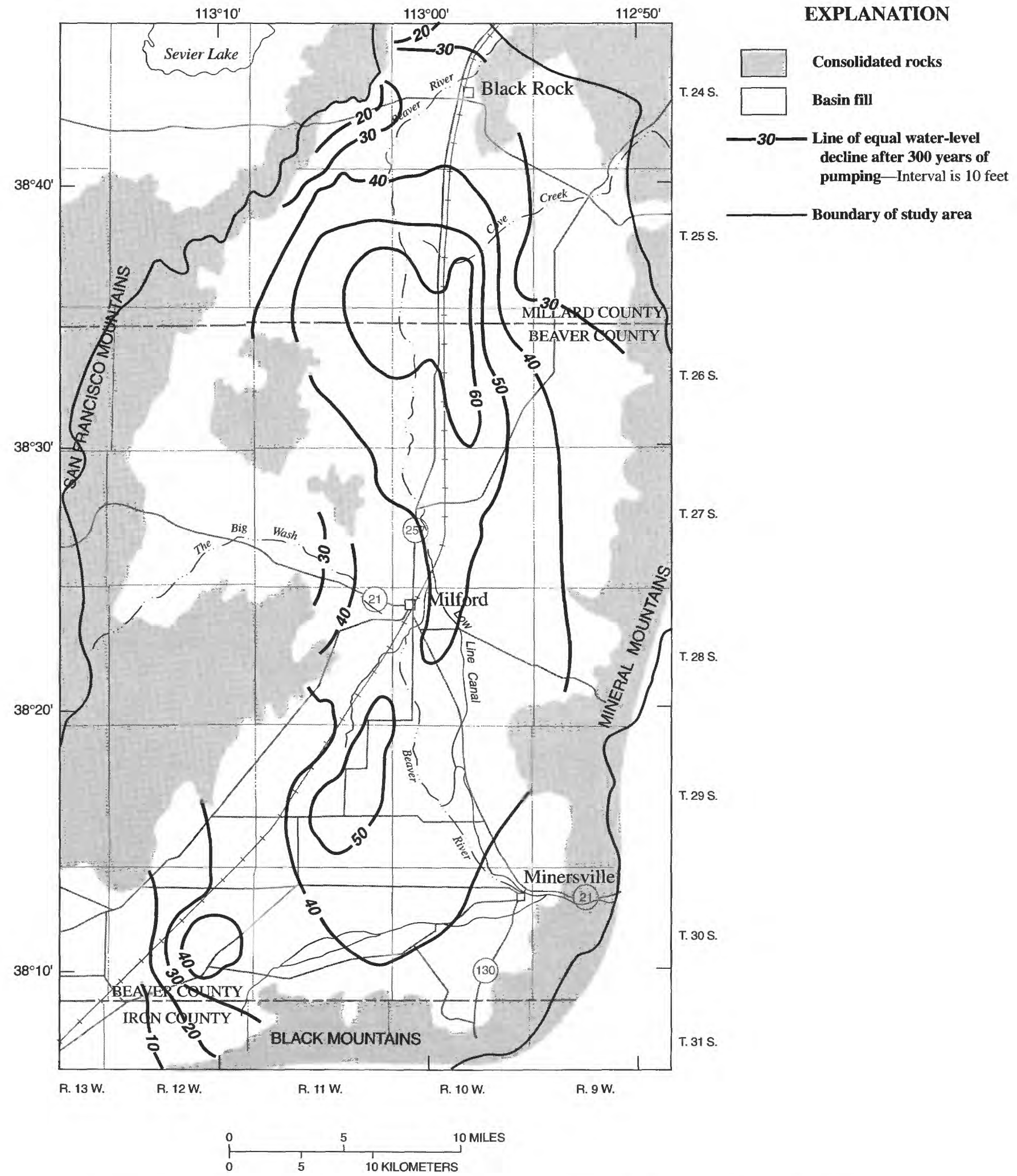

FIGURE 53.-Simulated water-level declines after 300 years of pumping for development alternative B3. 


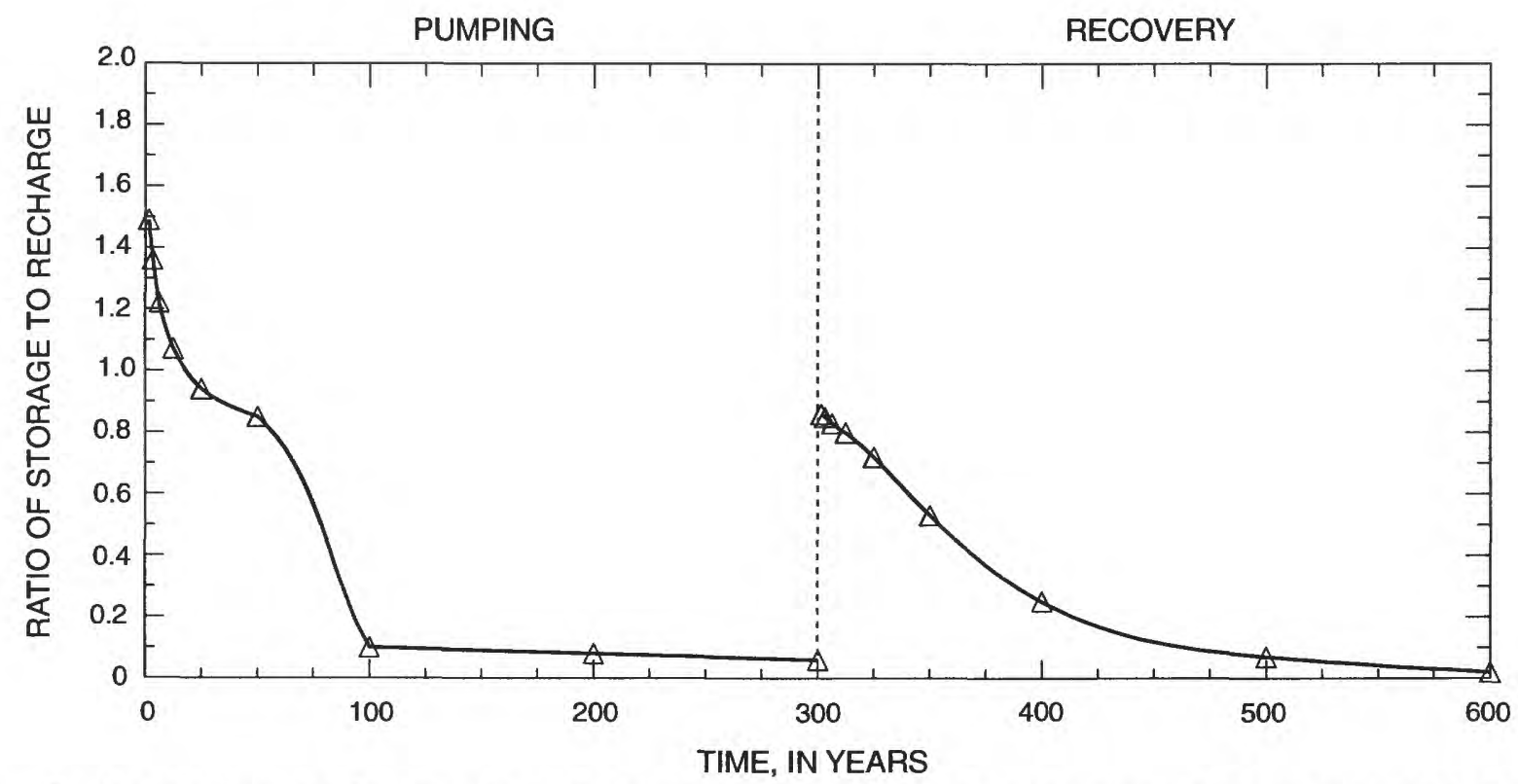

FIGURE 54.- Simulated changes in the ratios of water removed from storage during pumping to recharge and water added to storage during recovery to recharge for development alternative B3.

TABLE 5.-Cumulative total of simulated water removed from storage after pumping and recovery for each development alternative in the Milford area, Utah

[Data are in cubic feet; acre-feet shown in parentheses]

\begin{tabular}{ccc}
\hline $\begin{array}{c}\text { Development } \\
\text { alternative }\end{array}$ & $\begin{array}{c}\text { Following } \\
\text { pumping }\end{array}$ & $\begin{array}{c}\text { Following } \\
\text { recovery }\end{array}$ \\
\hline A1 & $1.88 \times 10^{11}$ & $4.53 \times 10^{9}$ \\
& $(4,320,000)$ & $(104,000)$ \\
A2 & $2.20 \times 10^{11}$ & $1.73 \times 10^{10}$ \\
& $(5,050,000)$ & $(397,000)$ \\
A3 & $1.53 \times 10^{11}$ & $6.85 \times 10^{9}$ \\
& $(3,510,000)$ & $(157,000)$ \\
B1 & $1.11 \times 10^{11}$ & $3.08 \times 10^{9}$ \\
& $(2,550,000)$ & $(70,700)$ \\
B2 & $2.06 \times 10^{11}$ & $7.21 \times 10^{9}$ \\
& $(4,730,000)$ & $(166,000)$ \\
B3 & $1.39 \times 10^{11}$ & $4.23 \times 10^{9}$ \\
& $(3,190,000)$ & $(97,100)$
\end{tabular}

\section{NEED FOR FUTURE STUDIES}

Transient simulations produced water-level declines at the basin fill-consolidated rock interface that might not occur if the consolidated rocks are able to yield and transmit water readily to the basin fill. In this study, the flux entering the ground-water system from consolidated rocks at the margin of the basin was determined initially by using constant-head cells along this boundary. Because of the lack of data, the estimated water levels at these cells may lead to uncertainty in the estimated flux. Additional well data and, if possible, aquifer-test data would help define the hydraulic properties of the basin fill at these boundaries and permit a better estimate for this uncertain component of the water budget.

This study redefined the flow direction in the northern one-half of the study area, using limited test-hole data. Additional data might better define the extent and quantity of basin outflow along the northwest boundary.

The vertical head gradient within the area of present ground-water development had to be estimated because water-level data solely from the confined aquifer were lacking. Data from newer wells completed only in the confined aquifer, without multiple perforated zones, might permit a refined conceptualization of the groundwater system. Aquifer tests using wells with limited perforated zones might permit better estimates of vertical hydraulic conductivity and vertical hydraulic gradient. With this information, transient simulations could project effects of future ground-water withdrawals within the developed area with greater accuracy. 


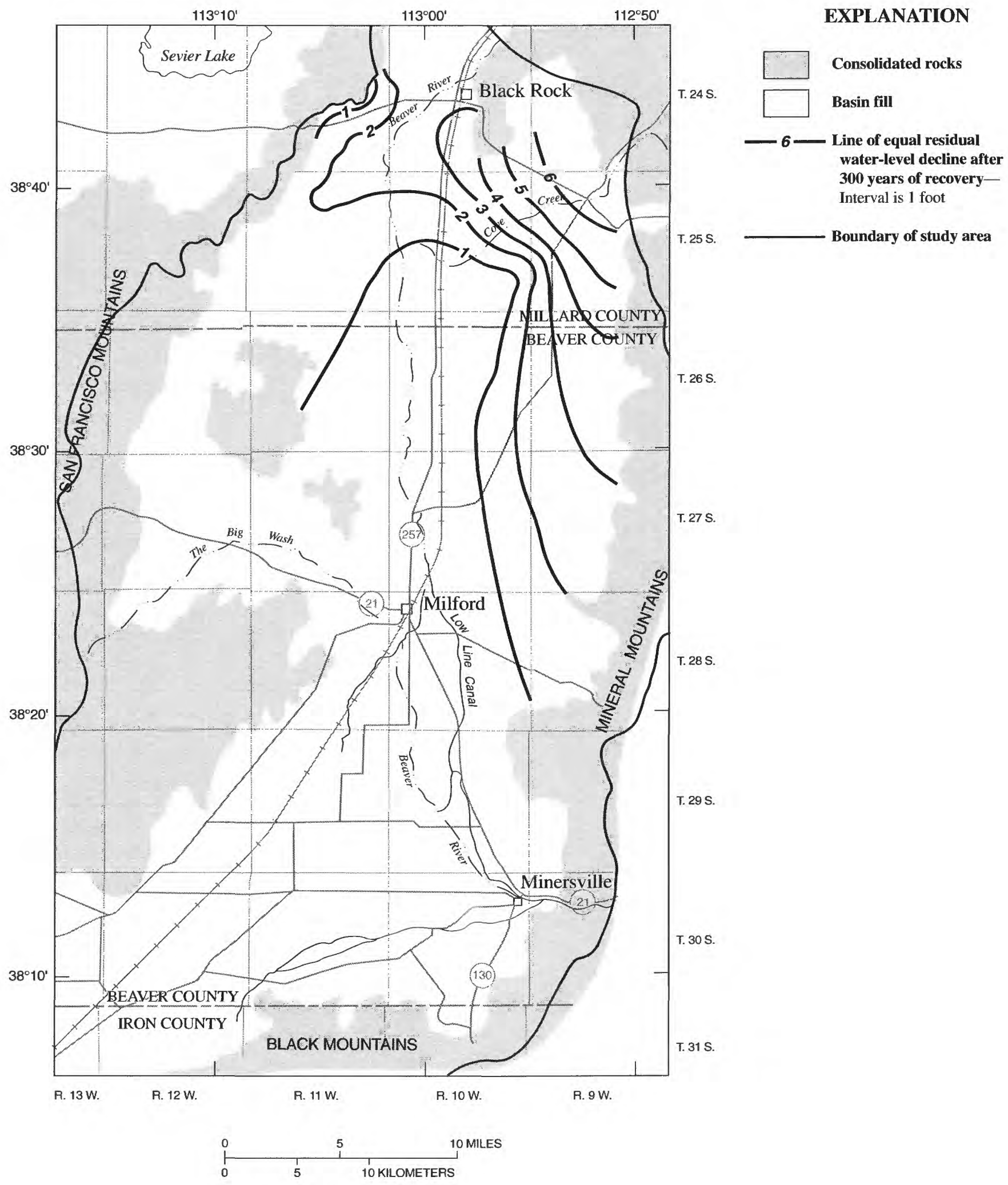

FIGURE 55.-Simulated residual water-level declines after 300 years of recovery for development alternative B3. 


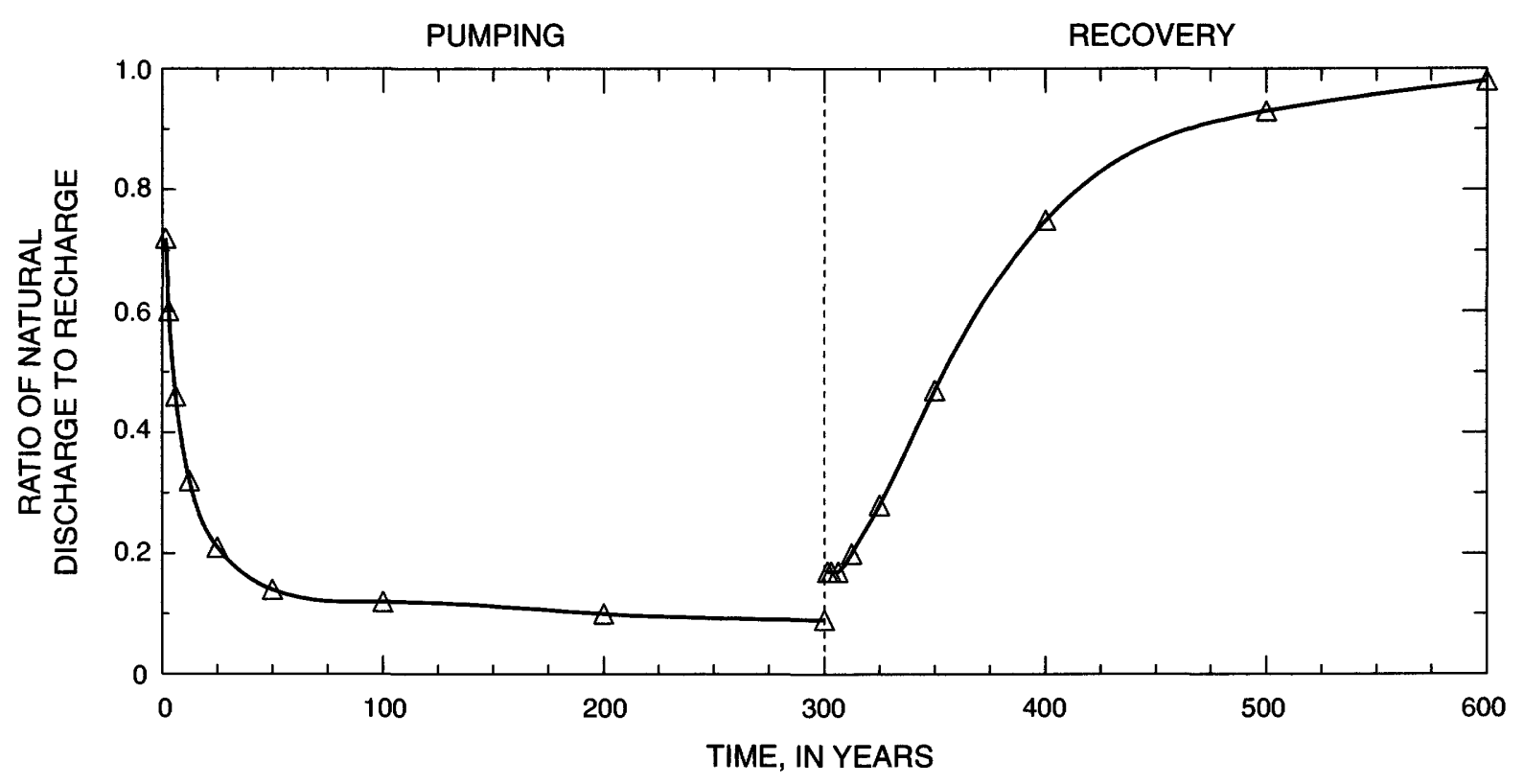

FIGURE 56.-Simulated change in the ratio of natural discharge to recharge during pumping and recovery for development alternative B3.

\section{SUMMARY}

As part of the Great Basin Regional Aquifer-System Analysis program, a three-dimensional, finite-difference model was constructed to simulate the ground-water system in the Milford area of southwestern Utah. The calibrated model was used to make short-term predictive simulations to estimate water-level declines using the current (1984) pumping distribution, and hypothetical long-term simulations using several different pumping distributions.

Ground-water movement in the basin-fill aquifer generally is from south to north with a prominent east-west component of flow from the eastern recharge boundary along the Mineral Mountains toward the center of the basin. Recharge from the western boundary appears to be inconsequential; therefore, the flow direction along the western margin basically parallels the main flow direction in the center of the basin. Measured and inferred water levels from new test holes in the northwest part of the basin indicate that ground water exits the basin in a northwesterly direction through the north end of the San Francisco Mountains rather than as underflow following the Beaver River drainage to the north.

The basin-fill aquifer was simulated by using three layers to represent the three-dimensional system. After the model was calibrated, simulations were able to approximate steady-state conditions for 1927 and transient conditions from 1950-82. Through steady-state calibration, subsurface inflow from consolidated rocks along the Mineral Mountains was computed to be almost 24,000 acre-ft/yr. Basin outflow to the northwest was computed to be more than $11,000 \mathrm{acre}-\mathrm{ft} / \mathrm{yr}$ and evapotranspiration was computed to be almost 27,000 acre-ft/yr. Two transient simulations using constant and varying recharge from surface water for each stress period were made to test the effects of these conditions on the ground-water system. With the present model-grid configuration, substantial differences in computed water-level changes between the two methods of simulating recharge are indicated in the vicinity of the Beaver River in the southeast part of the area; but, for most of the simulated area, minimal or no differences in water levels were indicated.

Sensitivity analysis showed that the largest changes in the computed-head distributions were caused by changes in recharge at the eastern boundary, evapotranspiration rates, and evapotranspiration extinction depths. Similarly, the largest changes in ground-water flow at headdependent boundaries, such as the general-head boundaries and the area of evapotranspiration, were caused by changes in recharge at the eastern boundary, evapotranspiration rates and extinction depths, and transmissivity values.

The calibrated ground-water flow model was used to make short-term predictive simulations over a 37-year period from 1983 to 2020 . Three simulations were made using rates of ground-water withdrawal equal to $1,1.5$, and 2 times the 1979-82 average rate. Water-level declines of about 6 to $12 \mathrm{ft}$ were projected using the average rate for 1979-82. The declines are minimal primarily because the average rate of withdrawal for 1979-82 is virtually 
equal to the estimated average annual recharge. At 1.5 times the 1979-82 average rate, projected maximum water-level declines increased to more than $35 \mathrm{ft}$. Although this rate of withdrawal was reached only once (1974) in the Milford area, future long-term average withdrawals could conceivably approach this level. As a worst-case simulation, maximum water-level declines of more than $70 \mathrm{ft}$ were projected using withdrawals equal to twice the 1979-82 average rate.

In order to test the concepts of "sustained" yield, ground-water mining, and the capture of natural discharge, several 600-year simulations were made using hypothetical distributions of ground-water withdrawals. Simulations using concentrated pumping centers were the least efficient at eliminating natural discharge and approaching new equilibrium conditions, and produced the largest water-level declines. Simulations using a distribution with ground-water withdrawals strategically placed in discharge areas were the most efficient at eliminating natural discharge, and in some cases approached a new equilibrium condition.

\section{REFERENGES GITED}

Appel, C.L., and others, 1983, Ground-water conditions in Utah, spring of 1983: Utah Division of Water Resources Cooperative Investigations Report No. 23, 97 p.

Armstrong, R.L., 1970, Geochronology of Tertiary igneous rocks, eastern Basin and Range Province, western Utah, eastern Nevada, and vicinity, U.S.A.: Geochimica et Cosmochimica Acta, v. 34, p. 203-232.

Arnow, Ted, and Mattick, R.E., 1968, Thickness of valley fill in the Jordan Valley east of Great Salt Lake, Utah: U.S. Geological Survey Professional Paper 600-B, p. B79-B82.

Avery, C.F., and others, 1984, Ground-water conditions in Utah, spring of 1984: Utah Division of Water Resources Cooperative Investigations Report No. 24, 79 p.

Bowman, J.R., and Rohrs, D.T., 1981, Light stable isotope studies of spring and thermal waters from the Roosevelt Hot Springs and Cove Fort/Sulphurdale thermal areas and of clay minerals from the Roosevelt Hot Springs thermal area: U.S. Department of Energy Report No. ID/12079-44, Department of Geology and Geophysics, University of Utah, 36 p.

Brumbaugh, W.D., and Cook, K.L., 1977, Gravity survey of the Cove Fort-Sulphurdale KGRA and the north Mineral Mountains area, Millard and Beaver Counties, Utah: U.S. Department of Energy Technical Report v. 77-4, contract EY-76-S-07-1601, Department of Geology and Geophysics, University of Utah, $130 \mathrm{p}$.

Carter, J.A., and Cook, K.L., 1978, Regional gravity and aeromagnetic surveys of the Mineral Mountains and vicinity, Millard and Beaver Counties, Utah: U.S. Department of Energy Final Report v. 77-11, contract EY-76-S-07-1601, Department of Geology and Geophysics, University of Utah, $179 \mathrm{p}$.

Condie, K.C., and Barsky, C.K., 1972, Origin of Quaternary basalts from the Black Rock Desert region, Utah: Geological Society of America Bulletin, v. 83, no. 2, p. 333-352.

Crebs, T.J., and Cook, K.L., 1976, Gravity and ground magnetic surveys of the central Mineral Mountains, Utah: Final Report v. 6,
National Science Foundation Grant GI-43741, Department of Geology and Geophysics, University of Utah, 129 p.

Criddle, W.D., 1958, Consumptive use and irrigation water requirements of Milford Valley: U.S. Department of Agriculture, Agriculture Research Service, 41-14, $45 \mathrm{p}$.

Dennis, P.E., 1942, Shorelines of the Escalante Bay of Lake Bonneville: Utah Academy of Science, Arts, and Letters Proceedings, v. 19, p. 121-124.

Fenneman, N.M., 1931, Physiography of the western United States: New York, McGraw-Hill, 534 p.

Gertson, R.C., and Smith, R.B., 1979, Interpretation of a seismic refraction profile across the Roosevelt Hot Springs, Utah and vicinity: U.S. Department of Energy Report No. ADO/78-1701.a.3, Department of Geology and Geophysics, University of Utah, $120 \mathrm{p}$.

Harrill, J.R., Welch, A.H., Prudic, D.E., Thomas, J.M., Carman, R.L., Plume, R.W., Gates, J.S., and Mason, J.L., 1983, Aquifer systems in the Great Basin region of Nevada, Utah, and adjacent states: A study plan: U.S. Geological Survey Open-File Report 82-445, $49 \mathrm{p}$.

Hintze, L.F., 1973, Geologic history of Utah: Brigham Young University Geology Studies, v. 20, part 3, 181 p.

1980, Geologic map of Utah: Utah Geological and Mineral Survey, 1 sheet, scale 1:500,000.

Keys, W.S., and MacCary, L.M., 1971, Applications of borehole geophysics to water-resources investigations: U.S. Geological Survey Techniques of Water-Resources Investigations, book 2 , chap. E1, $126 \mathrm{p}$.

Lemmon, D.M., and Morris, H.T., 1983, Preliminary geologic map of the Beaver Lake Mountains quadrangle, Beaver and Millard Counties, Utah: U.S. Geological Survey Open-File Report 83$181,14 \mathrm{p}$.

Lohman, S.W., 1972, Ground-water hydraulics: U.S. Geological Survey Professional Paper 708, 70 p.

Maxey, G.B., and Eakin, T.E., 1949, Ground water in White River Valley, White Pine, Nye, and Lincoln Counties, Nevada: Nevada State Engineer Water-Resources Bulletin No. 8, 59 p.

McDonald, M.G., and Harbaugh, A.W., 1988, A modular three-dimensional finite-difference ground-water flow model: U.S. Geological Survey Techniques of Water-Resources Investigations, book 6 , chap. A1, various pagination.

Moore, D.O., 1968, Estimating mean runoff in ungaged semiarid areas: Nevada Department of Conservation and Natural Resources Water-Resources Bulletin 36, p. 29-39.

Mower, R.W., 1982, Hydrology of the Beryl-Enterprise area, Escalante Desert, Utah, with emphasis on ground water: Utah Department of Natural Resources Technical Publication No. 73, 66 p.

Mower, R.W., and Cordova, R.M., 1974, Water resources of the Milford Area, Utah, with emphasis on ground water: Utah Department of Natural Resources Technical Publication No. 43, $106 \mathrm{p}$.

Mower, R.W., and Feltis, R.D., 1968, Ground-water hydrology of the Sevier Desert, Utah: U.S. Geological Survey Water-Supply Paper 1854, 75 p.

Nelson, W.B., 1950, Ground water in the Milford District in Fix, P.F., Nelson, W.B., Lofgren, B.E., and Butler, R G., Ground water in the Escalante Valley, Beaver, Iron, and Washington Counties, Utah: Utah State Engineer Technical Publication No. 6 (Utah State Engineer 27th Biennial Report), p. 180-210.

1954, Status of ground-water development in four irrigation districts in southwestern Utah, in Progress report on selected ground-water basins in Utah: Utah State Engineer Technical Publication No. 9, p. 5-93.

Nelson, W.B., and Thomas, H.E., 1952, Milford district of Escalante Valley, Beaver County, in Thomas, H.E., Nelson, W.B., Lofgren, B.E., and Butler, R.G., Status of development of selected ground- 
water basins in Utah: Utah State Engineer Technical Publication No. 7, p. 49-56.

Rohrs, D.T., and Bowman, J.R., 1980, A light stable isotope study of the Roosevelt Hot Springs area, southwestern Utah: U.S. Department of Energy Report No. IDO/78-1701.a.1.5, Department of Geology and Geophysics, University of Utah, $88 \mathrm{p}$.

Sandberg, G.W., 1962, Ground-water conditions in the Milford and Beryl-Enterprise districts and in Cedar City and Parowan Valleys, Utah, 1954-60: U.S. Geological Survey Open-File Report, $84 \mathrm{p}$.

1966, Ground-water resources of selected basins in southwestern Utah: Utah State Engineer Technical Publication No. 13, $46 \mathrm{p}$.

Seiler, R.L., and others, 1985, Ground-water conditions in Utah, spring of 1985: Utah Division of Water Resources, Cooperative Investigations Report No. 25, 84 p.

Smith, J.L., 1980, A model study of the regional hydrogeologic regime, Roosevelt Hot Springs, Utah: U.S. Department of Energy Report IDO/78-28392.a.10, Department of Geology and Geophysics, University of Utah, $30 \mathrm{p}$.
Thangsuphanich, I., 1976, Regional gravity survey over the southern Mineral Mountains, Beaver County, Utah: unpublished M.S. thesis, University of Utah, $37 \mathrm{p}$.

U.S. Weather Bureau, [1963], Normal annual and May-September precipitation (1931-60) for the State of Utah: Map of Utah, 2 sheets, scale 1:500,000.

Ward, S.H., Parry, W.T., Nash, W.P., Sill, W.R., Cook, K.L., Smith, R.B., Chapman, D.S., Brown, F.H., Whelan, J.A., and Bowman, J.R., 1978, A summary of the geology, geochemistry, and geophysics of the Roosevelt Hot Springs Thermal area, Utah: Geophysics, v. 43, p. 1515-1542.

White, W.N., 1932, A method of estimating ground-water supplies based on discharge by plants and evaporation from soil--results of investigations in Escalante Valley, Utah: U.S. Geological Survey Water-Supply Paper 659-A, p. 1-105.

Willardson, L.S., and Bishop, A.A., 1967, Analysis of surface irrigation application efficiency: American Society of Civil Engineers Proceedings, Journal of Irrigation and Drainage Division, v. 93, no. IR2, Paper 5267, p. 21-36. 